\title{
Barriers of ERP while implementing ERP: a Literature Review
}

\author{
Vijay M. Khaparde \\ Mechanical Engineering Dept., K.J. Somaiya College of Engineering, Mumbai University of Mumbai, India.
}

\begin{abstract}
Purpose - The main purpose of the paper is to do literature survey of ERP Papers (from refereed and International Journals like Elsevier, InderScience, ASME, Springer and ACM( Digital Library) to find out the barriers of ERP when implementing it. Thus, the objective of the paper is to study the literature review papers and find out the barriers of ERP.

Research findings of the paper: While implementing this ERP in an enterprise(s), it is found that there are obviously some barriers which need to be addressed. Out of 200 or so literature papers on ERP, 51 papers were reviewed for barriers and studied in depth. These barriers are mentioned in the form of Table in the literature survey. While implementing ERP, the barriers which are commonly observed are- huge capital incurred for software, poor planning or poor management, lack of perfection, lack of training and predetermined corporate goals, lack of good vendors, lack of risk assessment, lack of approach, lack of data models (support), lack of ERP Systems' benefits, lack of system performance, lack of hierarchical attribute structure and lack of management support etc.

Outline of the paper:

The tool or methodology applied to overcome these barriers is AHP. It analyses the barriers (of ERP) and can help to solve the issues of ERP for its implementation. The results after overcoming the barriers and implementing it are excellent, found to be more productive for the enterprises.
\end{abstract}

Keywords: ERP (Enterprise Resources Planning), Barriers, Software, System(s), Risk Assessment, AHP (Analytical Hierarchy Process).

\section{Introduction}

An enterprise resource planning (ERP) is an enterprise-wide application software package that integrates all necessary business functions into a single system with a common database. Enterprise resource planning (ERP) systems integrate and streamline the business processes of an organization across departmental and geographical borders.

In its basic definition, ERP is an enterprise-wide information system that integrates and controls all the business processes in the entire organization. According to Nah and Lau (2001) ERP is "a packaged business software system that enables a company to manage the efficient and effective use of resources (materials, human resources, finance, etc.) by providing a total, integrated solution for the organization's information-processing needs". This software facilitates, if well-implemented, the integration of all the functional information flows across the organization into a single package with a common database. Therefore, it allows easy and immediate access to information regarding inventory, product or customer data, and prior history information (Shehab et al., 2004).

Today, many public and private organizations worldwide are implementing ERP systems in place of the functional legacy systems that are not anymore well-compatible with modern business environment. However, according to Kroenke (2008), the process of moving from functional applications to an ERP system is difficult and challenging. Additionally, the switch to ERP system is expensive and it requires development of new procedures, training and converting data (Zhang et al., 2005). Enterprise resource planning systems, also called enterprise systems (ES) are among the most important business information technologies that emerged during the last decade. While no two industries' ERP systems are the same, the basic concept of ERP systems is focused on standardization and synchronization of information, and as a result, improved efficiency. The benefits of ERP systems include coordinating processes and information, reducing carrying costs, decreasing cycle time, and improving responsiveness to customer needs (Davenport 2000; Elarbi 2001).

The business environment is dramatically changing. Companies today face the challenge of increasing competition, expanding markets, and rising customer expectations. This increases the pressure on companies to lower total costs in the entire supply chain, shorten throughput times, drastically reduce inventories, expand product choice, provide more reliable delivery dates and better customer service, improve quality, and efficiently coordinate global demand, supply, and production [1].As the business world moves ever closer to a completely collaborative model and competitors upgrade their capabilities, to remain competitive, organizations must improve their own business practices and procedures. Companies must also increasingly share with their suppliers, distributors, and customers the critical in-house information they once aggressively protected [2]. And functions within the company must upgrade their capability to generate and communicate timely and accurate 
information. To accomplish these objectives, companies are increasingly turning to enterprise resource planning (ERP) systems. ERP provides two major benefits that do not exist in non-integrated departmental systems: (1) a unified enterprise view of the business that encompasses all functions and departments; and (2) an enterprise database where all business transactions are entered, recorded, processed, monitored, and reported. This unified view increases the requirement for, and the extent of, interdepartmental cooperation and coordination. But it enables companies to achieve their objectives of increased communication and responsiveness to all stakeholders [3].

From another aspect, ERP enables the integrated flow of information to be the core system that provides the data needed for all corporate components. In this way, how to take advantage of that information for the use of gaining competitive edge is the key to success.

\section{The promise and pitfalls of ERP and Significance of exploring ERP implementation issues}

Enterprise systems appear to be a dream come true. The commercially available software packages promise seamless integration of all information flows in the company --financial and accounting information, human resource information, supply chain information, and customer information. For managers who have struggled, at great expense and with great frustration, with incompatible information systems and inconsistent operating practices, the promise of a quasi "off-the-shelf" solution to the problem of business integration is enticing. Fig. 1 illustrates the scope of an enterprise system.

The list shows some of the many functions supported by an ERP System [3].

\section{Financials}

Accounts receivable and payable, Asset accounting, Cash management and forecasting, Cost-element and cost-center accounting, Executive information system, Financial consolidation, General ledger, Product cost accounting, Profitability analysis, Profit-center accounting, Standard and period-related costing

\section{Human Resources}

Human-resource time accounting, Payroll, Personnel planning, Travel expenses.

\section{Operations and Logistics}

Inventory management, Materials management, Plant maintenance, Production planning, Project management, Purchasing, Quality management, Routing management, Shipping, Vendor evaluation.

\section{Sales and Marketing}

Order management, Pricing, Sales management, Sales planning.

\section{Fig.1.: The scope of an enterprise system.}

\section{Why implementations fail}

The top three reasons for the failure of IT-related projects, as cited by IT managers surveyed by Information Week, were poor planning or poor management (cited by $77 \%$ ), change in business goals during the project $(75 \%)$, and lack of business management support (73\%). As a result, most IT-related projects fall far short of their potential payback, and $26 \%$ are canceled before completion. Moreover, in many of the completed projects, the technology is deployed in a vacuum and users resist it [8]. Langenwalter claims that the percentage of ERP implementations that can be classified as "failures" ranges from $40 \%$ to $60 \%$ or higher [14]. Ptak defines failure as an implementation that does not achieve the ROI identified in the project approval phase and finds that failure rates are in the range of $60-90 \%$ [23]. Based on the concepts presented in this paper, the reasons for failure can be placed into 10 categories [5,7,8,11,12-14,15]. These categories appear in Fig. 2 .

The reasons why ERP implementations fail can be placed into ten categories.

1. Strategic goals are not clearly defined.

2. Top management is not committed to the system.

3. Implementation project management is poor.

4. The organization is not committed to change.

5. A great implementation team is not selected.

6. Inadequate education and training results in users that are unable to satisfactorily run the system.

7. Data accuracy is not ensured.

8. Performance measures are not adopted to ensure that the organization changes.

9. Multi-site issues are not properly resolved. 
10. Technical difficulties can lead to implementation failures.

Fig. 2 . : Why ERP implementations fail.

\section{Critical factors for successful ERP implementation}

Implementing an ERP system is not an inexpensive or risk-free venture. In fact, $65 \%$ of executives believe that ERP systems have at least a moderate chance of hurting their businesses because of the potential for implementation problems [4]. It is therefore worthwhile to examine the factors that, to a great extent, determine whether the implementation will be successful. Numerous authors have identified a variety of factors that can be considered to be critical to the success of an ERP implementation. The most prominent of these are described below.

3.1. Clear understanding of strategic goals

3.2. Commitment by top management

3.3. Excellent project management

3.4. Organizational change management

3.5. A great implementation team

3.6. Data accuracy

3.7. Extensive education and training

3.8. Focused performance measures

3.9. Multi-site issues

Successful implementation of ERP requires the change in staff behavior, processes, departments and organizations: Seyed M.S. Hosseini (2012).

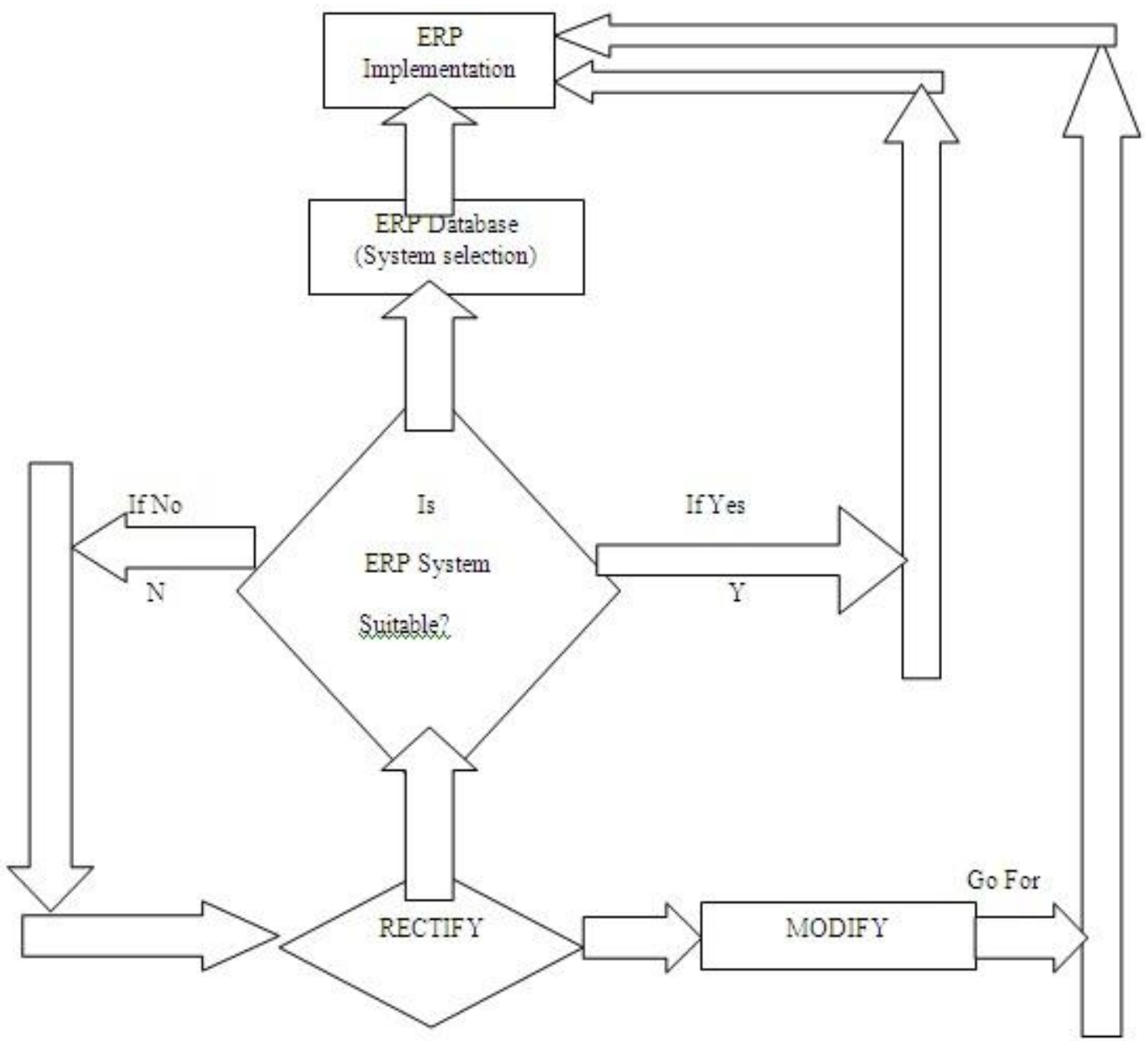

Fig. 3. Flowchart for an ERP system implementation process. 


\section{Literature review :}

While implementing ERP in an organization, there are following barriers which need to be addressed, are mentioned in the following Table-1.

\begin{tabular}{|c|c|c|c|c|c|c|}
\hline $\begin{array}{l}\text { Sr. } \\
\text { No. }\end{array}$ & $\begin{array}{l}\text { Categor } \\
y / \\
\text { Class }\end{array}$ & $\begin{array}{l}\text { Name of barrier } \\
\text { for } \quad \text { ERP } \\
\text { Implementation. }\end{array}$ & $\begin{array}{l}\text { Name of author } \\
\text { withyear }\end{array}$ & Key research findings by this author & $\begin{array}{l}\text { Methodology } \\
\text { Used }\end{array}$ & $\begin{array}{l}\text { Tool(s) } \\
\text { used }\end{array}$ \\
\hline 1 & Process & Lack of Perfection & $\begin{array}{l}\text { IkeC. Ehie, } \\
\text { Mogen Madsen, } \\
2005\end{array}$ & $\begin{array}{l}\text { 1) This study reports the results of an } \\
\text { empirical research on the critical issues } \\
\text { affecting successful ERP implementation. } \\
\text { 2) Eight factors were identified that } \\
\text { attempts to explain } 86 \% \text { of the variances } \\
\text { that impactERP implementation. }\end{array}$ & $\begin{array}{l}\text { Empirical } \\
\text { studies }\end{array}$ & $\begin{array}{r}\text { Primary } \\
\text { E } \\
R \\
P \\
\text { software }\end{array}$ \\
\hline 2 & Process & $\begin{array}{l}\text { Lack of software } \\
\text { acquisition process } \\
\& \\
\text { Complexities. }\end{array}$ & $\begin{array}{l}\text { 1.Jacques } \\
\text { Verville, } \\
\text { 2.Alannah } \\
\text { Halingten, } \\
2003\end{array}$ & $\begin{array}{l}\text { 1) Within this paper was presented a model } \\
\text { of the ERP software acquisition process } \\
\text { (MERPAP) that reflects the findings from } \\
\text { the four cases examined in this study. } \\
\text { 2) This high-level model depicts the } \\
\text { principal processes that pertain to the } \\
\text { acquisition of packaged software. } \\
\text { 3) It is not generalizable to a larger } \\
\text { population. }\end{array}$ & $\begin{array}{l}\text { ERP } \\
\qquad \begin{array}{l}\text { Soft } \\
\text { war }\end{array} \\
\text { e } \\
\text { Acquisition } \\
\text { Process. }\end{array}$ & $\begin{array}{l}\text { Six stage } \\
\begin{array}{r}m \\
0 \\
\text { de } \\
1\end{array} \\
\text { of ERP }\end{array}$ \\
\hline 3 & Process & $\begin{array}{l}\text { Lack of the } \\
\text { reactivity of } \\
\text { the planning } \\
\text { system. }\end{array}$ & $\begin{array}{l}\text { Claire Berchet, } \\
\text { Georges Habchi, } \\
2005\end{array}$ & $\begin{array}{l}\text { 1) A detailed model of the planning process } \\
\text { is built. 2) Develop a control helping system } \\
\text { based on performance indicators.3) Outline } \\
\text { the main results obtained at Alcatel in a } \\
\text { general way, and describe the risks, the } \\
\text { dysfunctions, and the reasons for them. }\end{array}$ & $\begin{array}{l}\text { Five-stage } \\
\text { deployment } \\
\text { model }\end{array}$ & $\begin{array}{l}\text { Integration } \\
\text { and } \\
\text { deployment } \\
\text { of the } \\
\text { planning } \\
\text { process }\end{array}$ \\
\hline 4 & Product & $\begin{array}{ll}\text { Lack } & \text { of } \\
\text { predetermined } \\
\text { corporate goals }\end{array}$ & $\begin{array}{l}\text { Elisabeth J } \\
\text { Umble }^{2} \text {, } \\
\text { Ronald R Haft, } \\
\text { M.Michael } \\
\text { Umble, } \\
2003\end{array}$ & $\begin{array}{l}\text { 1) This article identifies success factors, } \\
\text { software selection steps, and } \\
\text { implementation procedures critical to a } \\
\text { successful implementation. } \\
\text { 2) A case study of a largely success ful } \\
\text { ERP implementation is presented and } \\
\text { discussed interms of these key factors. }\end{array}$ & Case Study & $\begin{array}{l}\text { Enterprise } \\
\text { System } \\
\text { Software. }\end{array}$ \\
\hline 5 & Product & $\begin{array}{l}\text { Lack of Structured } \\
\text { GPM data. }\end{array}$ & $\begin{array}{l}\text { Souleiman } \\
\text { Naciri et al. } \\
2011\end{array}$ & $\begin{array}{l}\text { 1) This paper presents a methodology and a } \\
\text { translator that allow management data to be } \\
\text { included in a GPM data warehouse. } \\
\text { 2) The proposed framework enables data } \\
\text { management contained in flat Excel Files to } \\
\text { betranslated into structured GPM data. }\end{array}$ & $\begin{array}{l}\text { GPM } \\
\text { (Generic } \\
\text { Product } \\
\text { Model) }\end{array}$ & $\begin{array}{l}\text { ERP data } \\
\text { sharing } \\
\text { framework }\end{array}$ \\
\hline 6 & Product & $\begin{array}{l}\text { Lack of } \\
\text { organizational } \\
\text { barriers. }\end{array}$ & $\begin{array}{l}1 \quad \text { Boonserm } \\
\text { Kulvatunyou, } \\
2 \quad \text { Richard A. } \\
\text { Wysk } \\
2000\end{array}$ & $\begin{array}{l}\text { 1) Information models are necessary. } \\
\text { 2) Product quality will be high and cost will } \\
\text { be low. } \\
\text { 3) The dynamics of the engineering process } \\
\text { will be illustrated using these models. }\end{array}$ & $\begin{array}{l}\text { Information } \\
\text { Model. }\end{array}$ & $\begin{array}{l}\text { Engineerin } \\
\text { Process } \\
\text { Integration }\end{array}$ \\
\hline 7 & Issues & $\begin{array}{l}\text { Lack of Contextual } \\
\text { issues. }\end{array}$ & $\begin{array}{l}\text { Huigang Liang, } \\
\text { YajiongXue, } \\
2004\end{array}$ & $\begin{array}{l}\text { 1) From an ERP vendor's perspective, this } \\
\text { paper analyzes what can be done to } \\
\text { address contextual issues relating } \\
\text { to ERP implementation. } \\
\text { 2) The case of UFSoft, a Chinese ERP } \\
\text { vendor, reveals three strategies that could be } \\
\text { useful for achieving fit } \\
\text { between ERP systems and adopting } \\
\text { organizations. }\end{array}$ & $\begin{array}{l}\text { Case research } \\
\text { method- ERP } \\
\text { Vendor, UF } \\
\text { Soft. }\end{array}$ & BPR \\
\hline
\end{tabular}




\begin{tabular}{|c|c|c|c|c|c|c|}
\hline 8 & $\begin{array}{l}\text { Manage } \\
\text { ment }\end{array}$ & $\begin{array}{ll}\text { Lack } & \text { of } \\
\text { management } & \text { of } \\
\text { knowledge. } & \end{array}$ & $\begin{array}{l}\text { Ramin Vandaie } \\
2008\end{array}$ & $\begin{array}{l}\text { 1) This paper identifies two major areas of } \\
\text { concern regarding the management of ERP } \\
\text { knowledge. } \\
\text { 2) The first area concerns the effects and } \\
\text { implications of the tacitness of a great } \\
\text { portion ofERP-specific knowledge. } \\
\text { 3) The second area examines the } \\
\text { application of organizational memory in } \\
\text { ERP knowledge management. }\end{array}$ & $\begin{array}{l}\text { Cross- } \\
\quad \text { func } \\
\text { tion } \\
\text { nal and cross- } \\
\text { divisional } \\
\text { transfer of } \\
\text { Knowledge. }\end{array}$ & \begin{tabular}{|l|} 
Tacit \\
Knowledge \\
$(\mathrm{KM})$
\end{tabular} \\
\hline 9 & $\begin{array}{l}\text { Factors } \\
\text { (risk) }\end{array}$ & $\begin{array}{l}\text { Lack of risk } \\
\text { assessment }\end{array}$ & $\begin{array}{l}\text { Davide Aloini, } \\
\text { Riccardo } \\
\text { Dulmin, } \\
\text { Valeria Mininno, } \\
\quad 2012\end{array}$ & $\begin{array}{l}\text { 1) This work shows how } \\
\text { colored PetriNets (CPNs) can be used to } \\
\text { model risk factors in ERP projects in order } \\
\text { to deal with the problem of interdependence } \\
\text { in risk assessment. } \\
\text { 2) The technique is presented through an } \\
\text { application to a real case study. } \\
\text { 3) Findings highlight the importance of } \\
\text { interdependence and the indirect links for an } \\
\text { effective ranking of risks. }\end{array}$ & $\begin{array}{l}\text { A PetriNet } \\
\text { Approach. }\end{array}$ & Case study \\
\hline 10 & Factors & $\begin{array}{l}\text { Lack of data } \\
\text { analysis. }\end{array}$ & $\begin{array}{l}\text { AminAmid, } \\
\text { Morteza } \\
\text { Moalagh, } \\
\text { Ahad Zare } \\
\text { Ravasan, } \\
2012\end{array}$ & $\begin{array}{l}\text { 1) } 47 \text { failure factors were identified. } \\
\text { 2) Robust Exploratory Factor Analysis } \\
\text { (EFA) has been used for data analysis, } \\
\text { which finally classified critical failure } \\
\text { factors in seven groups named as vendor } \\
\text { and consultant, human resources, } \\
\text { managerial, project management, processes, } \\
\text { organizational and technical. }\end{array}$ & Data & \begin{tabular}{l} 
Robust \\
EFA \\
Explorator \\
\multicolumn{1}{|c|}{$\quad y$} \\
Factor \\
Analysis
\end{tabular} \\
\hline 11 & Factors & Lack of approach & $\begin{array}{l}\text { Davide Aloini, } \\
\text { Riccardo } \\
\text { Dulmin, } \\
\text { Valeria Mininno } \\
2012\end{array}$ & $\begin{array}{l}\text { 1) The different approaches taken in the } \\
\text { literature were compared from a risk } \\
\text { management point of view to highlight the } \\
\text { key risk factors and their impact on project } \\
\text { success. } \\
\text { 2) Literature was further classified in order } \\
\text { to address and analyze each risk factor and } \\
\text { its relevance during the stages of the ERP } \\
\text { project life cycle. }\end{array}$ & $\begin{array}{l}\text { Classification } \\
\text { \& } \\
\text { Analyze. }\end{array}$ & $\begin{array}{l}\text { Innovative } \\
\text { Technique- } \\
\text { Risk } \\
\text { Analysis }\end{array}$ \\
\hline 12 & Factors & $\begin{array}{l}\text { Lack of Critical } \\
\text { success factors. }\end{array}$ & $\begin{array}{l}\text { Joseph Bradley } \\
2008\end{array}$ & $\begin{array}{l}\text { 1) The findings suggest that choosing the } \\
\text { right full time project manager, training of } \\
\text { personnel, and the presence of a champion } \\
\text { relate to project success. } \\
\text { 2) Integration of ERP planning with } \\
\text { business planning, reporting level of the } \\
\text { project manager, and active participation of } \\
\text { the CEO beyond project approvals, resource } \\
\text { allocation and occasional project review, are } \\
\text { not found to be critical factors of success. } \\
\text { 3) All organizations implementing ERP, } \\
\text { especially small and mid-sized enterprises } \\
\text { with limited resources, will benefit from this } \\
\text { knowledge. }\end{array}$ & $\begin{array}{l}\text { This study is } \\
\quad \text { a } \\
\text { review of } \\
\text { literature on } \\
\text { ERP. } \\
\text { (ABI Inform, } \\
\text { Emerald, } \\
\text { ScienceDirect } \\
\text { and ACM } \\
\text { Digital } \\
\text { Library). }\end{array}$ & $\begin{array}{l}\begin{array}{l}\text { Framework } \\
\text { of classical } \\
\text { manageme } \\
\text { nt }\end{array} \\
\text { Theory. }\end{array}$ \\
\hline 13 & Industry & $\begin{array}{l}\text { Lack of ERP } \\
\text { systems benefits. }\end{array}$ & $\begin{array}{l}\text { Daniel E. } \\
\text { O'Leary } \\
\text { University of So } \\
\text { uthern California } \\
2005\end{array}$ & $\begin{array}{l}\text { 1) It is found that some benefits vary by } \\
\text { industry. } \\
\text { 2) In particular, tangible benefits are largely } \\
\text { industry dependent; with intangible benefits } \\
\text { vary across industry. } \\
\text { 3) In addition, when compared to an earlier } \\
\text { study by Deloitte Consulting, the results are } \\
\text { statistically consistent with their findings, } \\
\text { but find additional intangible benefits. }\end{array}$ & \begin{tabular}{|l} 
ERP \\
Database.
\end{tabular} & $\begin{array}{l}\text { Statistical } \\
\text { tool }\end{array}$ \\
\hline 14 & $\begin{array}{l}\text { Firm/ } \\
\text { Industry }\end{array}$ & $\begin{array}{l}\text { Lack of firm } \\
\text { competences. }\end{array}$ & $\begin{array}{l}\text { 1. Yi-fen Su, } \\
\text { 2. Chyan|Yang. } \\
2010\end{array}$ & $\begin{array}{l}\text { 1) The results provide empirical evidence } \\
\text { that the beneficial impacts of ERP on the } \\
\text { supply chain do lead to better overall SCM } \\
\text { competence. } \\
\text { 2) Enhance firm competences of SCM in } \\
\text { operational process integration, customer } \\
\text { and relationship integration, and planning } \\
\text { and control process integration. }\end{array}$ & SEM & $\begin{array}{l}\text { Conceptual } \\
\text { Framework }\end{array}$ \\
\hline
\end{tabular}




\begin{tabular}{|c|c|c|c|c|c|c|}
\hline 15 & Man & $\begin{array}{l}\text { Lack of data } \\
\text { models. }\end{array}$ & $\begin{array}{lr}\text { Daniel } & E . \\
\text { O'Leary } & 2005\end{array}$ & $\begin{array}{l}\text { 1) These compromises are based on the use } \\
\text { of accounting artifacts and other, often, } \\
\text { implementation-specific compromises. } \\
\text { 2) In addition, there are emerging } \\
\text { differences between the two. }\end{array}$ & $\begin{array}{l}\text { REA } \\
\text { (Resources- } \\
\text { Events- } \\
\text { Agents a } \\
\text { theoretical } \\
\text { accounting } \\
\text { enterprise } \\
\text { database } \\
\text { model) } \\
\text { And SAP. }\end{array}$ & $\begin{array}{l}\text { A } \\
\text { theoretical } \\
\text { accounting } \\
\text { enterprise } \\
\text { database } \\
\text { model }\end{array}$ \\
\hline 16 & $\begin{array}{l}\text { Analysi } \\
\mathrm{s}\end{array}$ & $\begin{array}{ll}\begin{array}{l}\text { Foreign } \\
\text { vendors }\end{array} & \text { ERP } \\
\text { failed. } \\
\text { (lack of } \\
\text { vendors) }\end{array}$ & $\begin{array}{l}\text { Yajiong Xue }^{2,} \\
\text { Huigang } \\
\text { Liang }^{b}, \\
\text { William } \\
\text { Boulton', } \\
\text { Charles } \\
\text { Snyder, } \quad \text { A. } \\
\text { 2005 }\end{array}$ & $\begin{array}{l}\text { 1) From the social-cultural perspective, five } \\
\text { cases in which foreign ERP vendors have } \\
\text { failed in their work. } \\
\text { 2) Chinese implementations are presented } \\
\text { and analyzed. } \\
\text { 3) Eight factors are identified which have } \\
\text { contributed to ERP failure. } \\
\text { 4) Implications of the findings for future } \\
\text { ERP implementations in China are } \\
\text { discussed. }\end{array}$ & $\begin{array}{l}\text { Historical } \\
\text { Perspective }\end{array}$ & $\begin{array}{l}\text { ERP } \\
\text { Vendor } \\
\text { Software } \\
\text { SAP } \\
\text { Oracle }\end{array}$ \\
\hline 17 & $\begin{array}{l}\text { Analysi } \\
\mathrm{s}\end{array}$ & $\begin{array}{ll}\text { Lack } & \text { of } \\
\text { augmentation }\end{array}$ & $\begin{array}{l}\text { Vincent A. } \\
\text { Mabert1, Ashok } \\
\text { Soni, } \\
\text { M.A. } \\
\text { Venkataramanan } \\
2006 . \\
\text { Model based } \\
\end{array}$ & $\begin{array}{l}\text { 1) Using multiple modeling techniques can } \\
\text { augment the findings from survey data and } \\
\text { provide greater insight. } \\
\text { 2) Each provides unique perspectives into } \\
\text { The process and helps to develop a } \\
\text { complete picture of the ERP landscape. }\end{array}$ & DEA & $\begin{array}{l}\text { Mathemati } \\
\text { cal \& } \\
\text { Computer } \\
\text { Model } \\
\text { (tool). }\end{array}$ \\
\hline 18 & $\begin{array}{l}\text { Analysi } \\
s\end{array}$ & $\begin{array}{l}\text { Lack of Critical } \\
\text { factors. }\end{array}$ & $\begin{array}{l}\text { 1. Boo Young } \\
\text { Chung } r 2 . \\
\text { Miroslaw } \\
\text { Skibniewski } \\
\text { 3. Henry C. } \\
\text { Lucas Jr; \& } 4 . \\
\text { Young Hoon } \\
\text { Kwak } 2008\end{array}$ & $\begin{array}{l}\text { 1) The main research findings here is that } \\
\text { the new factor postulated from this study, } \\
\text { function, was highly associated with } \\
\text { perceived usefulness. } \\
\text { 2) Subjective norm had a significant } \\
\text { association with perceived usefulness. }\end{array}$ & $\begin{array}{l}\text { Information } \\
\text { system } \\
\text { success } \\
\text { model }\end{array}$ & $\begin{array}{l}\text { Postulation } \\
\text { of } \\
\text { Factor(s). }\end{array}$ \\
\hline 19 & Game & $\begin{array}{l}\text { Lack of Passive } \\
\text { learning }\end{array}$ & $\begin{array}{l}\text { DESHPANDE, } \\
\text { AMIT } \\
\text { A. (deshpaaa/ae } \\
\text { mail.uc.edu) } \\
\text { Univ. } \\
\text { Cincinnati, of } \\
\text { ISBN, } 2008 \\
\text { Length } 188 \text { pages }\end{array}$ & $\begin{array}{l}\text { 1) Constructivist learning by the use of } \\
\text { simulation game. } \\
\text { 2) Objectivist instructor led learning and } \\
\text { collaborative learning through peer-to-peer } \\
\text { interaction. }\end{array}$ & $\begin{array}{l}\text { Motivation- } \\
\text { based multi- } \\
\text { source active } \\
\text { learning } \\
\text { methodology }\end{array}$ & $\begin{array}{l}\text { Game } \\
\text { based } \\
\text { Learning- } \\
\text { Simulation } \\
\text { Game. }\end{array}$ \\
\hline 20 & Control & $\begin{array}{l}\text { Lack of } \\
\text { Complementary } \\
\text { control. }\end{array}$ & $\begin{array}{ll}\text { Severing } & \text { V. } \\
\text { Grabski }^{2}, & \\
\text { Stewart } & \text { A. } \\
\text { Leech, } & \\
2007 & \end{array}$ & $\begin{array}{l}\text { 1) Research has demonstrated that single } \\
\text { modes of control are not sufficient, rather } \\
\text { than a portfolio of control modes should be } \\
\text { utilized. } \\
\text { 2) The results provide support for the theory } \\
\text { of complementary as applied to controls } \\
\text { needed to achieve a successful ERP } \\
\text { implementation. }\end{array}$ & $\begin{array}{l}\text { ERP } \\
\text { implementati } \\
\text { on } \\
\text { projects- } \\
\text { Control } \\
\text { modes. }\end{array}$ & $\begin{array}{l}\text { SAP, } \\
\text { BAAN, } \\
\text { Oracle, } \\
\text { QAD \& } \\
\text { Factor } \\
\text { Analysis }\end{array}$ \\
\hline 21 & Method & $\begin{array}{l}\text { Lack of Multi- } \\
\text { method analysis }\end{array}$ & $\begin{array}{l}\text { Craig Shepherd } 1 \text {, } \\
\text { Chris Clegg } 2 \text { and } \\
\text { Chris S tride } \\
2009\end{array}$ & $\begin{array}{l}\text { 1) Provided useful recommendations for } \\
\text { practitioners which corroborate wider } \\
\text { findings within the change management } \\
\text { literature (e.g., importance of adequate } \\
\text { training and communication of end users). }\end{array}$ & $\begin{array}{l}\text { Discourse } \\
\text { analysis of } \\
\text { interviews } \\
\text { and focus } \\
\text { groups } \\
\end{array}$ & $\begin{array}{l}\text { Statistical } \\
\text { Analysis }\end{array}$ \\
\hline 22 & $\begin{array}{l}\text { Method } \\
\text { Module. }\end{array}$ & $\begin{array}{l}\text { Lack of conceptual } \\
\text { framework. }\end{array}$ & 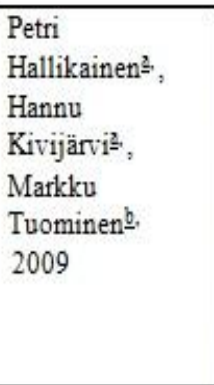 & $\begin{array}{l}\text { 1) Present first a general level conceptual } \\
\text { framework to ERP module } \\
\text { implementations. } \\
\text { 2) It expands the model to a more detailed } \\
\text { level in a case study. } \\
\text { 3) The priorities for } \\
\text { the implementation sequence of the ERP } \\
\text { modules are determined in the case study. }\end{array}$ & $\begin{array}{l}\text { Module/case } \\
\text { Study. }\end{array}$ & ERPModel \\
\hline
\end{tabular}




\begin{tabular}{|c|c|c|c|c|c|c|}
\hline 23 & $\begin{array}{l}\text { Method } \\
\text { Process. }\end{array}$ & $\begin{array}{l}\text { Lack of both } \\
\text { imitative and } \\
\text { logical evaluation } \\
\text { forces. }\end{array}$ & $\begin{array}{l}\text { Vincent S. Lai, } \\
\text { Connie K.W. } \\
\text { Liu, Fujun Lai, } \\
\text { Jian Wang, } \\
2010\end{array}$ & $\begin{array}{l}\text { 1) ERP adoption time and extent have } \\
\text { different effects on imitation and logical } \\
\text { evaluation behaviors. } \\
\text { 2) Imitative forces play a crucial role in the } \\
\text { decision-making process. } \\
\text { 3) It opens up a new avenue for research } \\
\text { into technologyadoption. }\end{array}$ & $\begin{array}{l}\text { Integrated } \\
\text { Model }\end{array}$ & $\begin{array}{l}\text { Innovation } \\
\& \\
\text { Imitation. }\end{array}$ \\
\hline 24 & Test & $\begin{array}{l}\text { Lack of Group } \\
\text { cohesion. }\end{array}$ & $\begin{array}{l}\text { Eric T.G. Wang, } \\
\text { Ta-Chung Ying, } \\
\text { James J. Jiang, } \\
\text { Gary Klein } \\
2006\end{array}$ & $\begin{array}{l}\text { 1) Group cohesion is positively related to } \\
\text { meeting management goals. } \\
\text { 2) Group cohesion is likewise positively } \\
\text { related to meeting management goals. }\end{array}$ & $\begin{array}{l}\text { Survey and } \\
\text { Data support }\end{array}$ & $\begin{array}{l}\text { Empirical } \\
\text { Relationshi } \\
\text { p } \\
\text { Tool }\end{array}$ \\
\hline 25 & Test & $\begin{array}{l}\text { Lack of Post- } \\
\text { implementation } \\
\text { success. }\end{array}$ & $\begin{array}{l}\text { Yan } \mathrm{Zhu,} \\
\text { Yan } \mathrm{Li} \text {, } \\
\text { Weiquan Wang, } \\
\text { Jian Chen } \\
2010\end{array}$ & $\begin{array}{l}\text { 1) Both ERP implementation quality and } \\
\text { organizational readiness significantly affect } \\
\text { post-implementation success, whereas } \\
\text { external support does not. } \\
\text { 2) The theoretical and practical } \\
\text { implications of the findings are discussed. }\end{array}$ & $\begin{array}{l}\text { Integrative } \\
\text { model }\end{array}$ & $\begin{array}{l}\text { Integrative } \\
\text { model }\end{array}$ \\
\hline 26 & Model & $\begin{array}{l}\text { Lack of Decisive } \\
\text { factors }\end{array}$ & $\begin{array}{l}\text { Salvador Bueno, } \\
\text { Jose L }\end{array}$ & $\begin{array}{l}\text { 1) This research model has offered some } \\
\text { evidence about main acceptance factors } \\
\text { on ERP which help to set the users' } \\
\text { behavior toward ERP. }\end{array}$ & $\begin{array}{l}\text { Technology } \\
\text { Acceptance } \\
\text { Model } \\
\text { (TAM) }\end{array}$ & $\begin{array}{l}\text { Research } \\
\text { Model }\end{array}$ \\
\hline 27 & Policy & $\begin{array}{l}\text { Lack of Engines of } \\
\text { economic growth. }\end{array}$ & $\begin{array}{l}\text { Helena Lenihan, } \\
2011\end{array}$ & $\begin{array}{l}\text { 1) Enterprise evaluation metrics are too } \\
\text { narrow. } \\
\text { 2) They focus almost exclusively on private } \\
\text { firm impacts. } \\
\text { 3) Illustrate how logic models could be } \\
\text { expanded to account for these broader } \\
\text { impacts. }\end{array}$ & $\begin{array}{l}\text { 'new' } \\
\text { Enterprise } \\
\text { policies. }\end{array}$ & $\begin{array}{l}\text { Logic } \\
\text { models }\end{array}$ \\
\hline 28 & Project & $\begin{array}{l}\text { Lack of Consulting } \\
\text { fees }\end{array}$ & $\begin{array}{l}\text { Malgorzata } \\
\text { Plaza }^{5}, \quad 2008 \\
\text { Katrin Rohlf } \\
2008\end{array}$ & $\begin{array}{l}\text { This research offers three major } \\
\text { contributions: } \\
\text { 1) a means of selecting a training strategy } \\
\text { that minimizes project consulting costs, } \\
\text { 2) an analytical method for accurately } \\
\text { predicting a project completion date, and } \\
\text { 3) a theoretical basis for empirical studies } \\
\text { of learning and ERP (and other IT) } \\
\text { implementations. }\end{array}$ & $\begin{array}{l}\text { Analytical } \\
\text { Modeling }\end{array}$ & $\begin{array}{l}\text { Analytical } \\
\text { tools }\end{array}$ \\
\hline 29 & Project & $\begin{array}{l}\text { Lack of } \\
\text { hierarchical } \\
\text { attribute structure. }\end{array}$ & $\begin{array}{l}\text { 1. Chun-Chin } \\
\text { Wei, } \\
\text { 2. Mao-Jiun J. } \\
\text { Wang, 2004 }\end{array}$ & $\begin{array}{l}\text { 1) A hierarchical attribute structure is } \\
\text { proposed to evaluate ERP projects } \\
\text { systematically. } \\
\text { 2) An actual example in Taiwan } \\
\text { demonstrates the feasibility of applying the } \\
\text { proposed framework. }\end{array}$ & $\begin{array}{l}\text { Fuzzy set } \\
\text { theory }\end{array}$ & AHP \\
\hline 30 & $\begin{array}{l}\text { Enterpri } \\
\text { se }\end{array}$ & Lack of activities & $\begin{array}{l}\text { V. Chapurlat, C. } \\
\text { Braesch } \\
2008\end{array}$ & $\begin{array}{l}\text { 1) The first part introduces the concepts and } \\
\text { definitions required } \\
\text { 2) State of the art concerning the uses, best } \\
\text { practices and main current research related } \\
\text { to VVQC in the enterprise field. } \\
\text { 3) Some orientations for future research to } \\
\text { be prioritized in order to deal with crucial } \\
\text { challenges in the enterprise. }\end{array}$ & $\begin{array}{l}\text { Enterprise- } \\
\text { modeling } \\
\text { Domain. }\end{array}$ & VVQC \\
\hline 31 & $\begin{array}{l}\text { Data } \\
\text { base }\end{array}$ & $\begin{array}{l}\text { Lack of modeling } \\
\text { language \& ERP } \\
\text { system's } \\
\text { functionality. }\end{array}$ & $\begin{array}{l}\text { 1.Pnina Soffer, } \\
\text { 2.Boaz Golany, } \\
\text { 3.Dov Dori } \\
2003\end{array}$ & $\begin{array}{l}\text { 1) Capturing the entire scope of process } \\
\text { variants supported by the ERP system. } \\
\text { 2) Interdependencies among them. } \\
\text { 3) Generic steps may be applied using a } \\
\text { variety of modeling languages. }\end{array}$ & $\begin{array}{l}\text { Object- } \\
\text { Process } \\
\text { modeling } \\
\text { (OPM) } \\
\text { Methodology. }\end{array}$ & $\begin{array}{l}\text { Reverse } \\
\text { engineering } \\
\text { process }\end{array}$ \\
\hline 32 & $\begin{array}{l}\text { Case } \\
\text { study }\end{array}$ & $\begin{array}{l}\text { Lack of Business, } \\
\text { technical and } \\
\text { cultural issues. }\end{array}$ & $\begin{array}{l}\text { 1. Yahaya Yusuf, } \\
2 \text { A } \\
\text { Gunasegaram, } \\
\text { 3. Mark S } \\
\text { Abthorpe } \\
2004\end{array}$ & $\begin{array}{l}\text { 1) The paper takes an in-depth look at the } \\
\text { issues behind the process of ERP } \\
\text { implementation via a case study } \\
\text { methodology. } \\
\text { 2) It focuses on business and technical as } \\
\text { well as cultural issues at the heart of the } \\
\text { Rolls-Royce implementation. } \\
\text { 3) The case study also looks at the } \\
\text { implementation time scales and assesses the } \\
\text { benefits from the project both tangible and } \\
\text { intangible. }\end{array}$ & $\begin{array}{l}\text { ERP System- } \\
\text { SAP R/3. }\end{array}$ & $\begin{array}{l}\text { Advanced } \\
\text { Business } \\
\text { Application } \\
\text { Programmi } \\
\text { ng } \\
\text { (ABAP) }\end{array}$ \\
\hline
\end{tabular}




\begin{tabular}{|c|c|c|c|c|c|c|}
\hline 33 & $\begin{array}{l}\text { Data/ } \\
\text { System }\end{array}$ & $\begin{array}{l}\text { Lack of cultural } \\
\text { barriers }\end{array}$ & \begin{tabular}{|l|} 
1. Mary C. \\
Jones, \\
2. Melinda \\
Cline, \\
3. Sherry Ryan, \\
2006
\end{tabular} & $\begin{array}{l}\text { 1) A model is developed that demonstrates } \\
\text { the link between the dimensions of culture } \\
\text { and knowledge sharing during ERP } \\
\text { implementation. } \\
\text { 2) Possible research questions on which } \\
\text { future research can be based are also } \\
\text { identified. }\end{array}$ & Model. & \begin{tabular}{|l} 
Knowledge \\
Sharing
\end{tabular} \\
\hline 34 & $\begin{array}{l}\mathrm{S} / \mathrm{w} \\
\text { system }\end{array}$ & Lack of expert tool & $\begin{array}{l}\text { M. Ghazanfari, } \\
\text { M. Jafari, } \\
\text { S. Rouhani, } \\
2011\end{array}$ & $\begin{array}{l}\text { 1) Enterprises can use this approach to } \\
\text { evaluate, select, and buy software } \\
\text { and systems. } \\
\text { 2) It provides better decision support for } \\
\text { their organizational environment, enabling } \\
\text { them to achieve competitive advantage. }\end{array}$ & BI & DSS \\
\hline 35 & System & $\begin{array}{lr}\text { Lack } & \text { of } \\
\text { Acceptance factors. }\end{array}$ & $\begin{array}{|lr|}\text { 2.Adam. } & \text { R } \\
\text { 2. Kotzé. } & \text { P } \\
\text { 3. Van } & \text { der } \\
\text { Merwe. A } & \\
\text { 2011 } & \end{array}$ & $\begin{array}{l}\text { 1mis paper addresses the gap by } \\
\text { considering the strategic, business, technical } \\
\text { and human factors. } \\
\text { 2) It influences the acceptance of ERP } \\
\text { systems in small manufacturing enterprises } \\
\text { in South Africa. }\end{array}$ & \begin{tabular}{|l|} 
ERP \\
System(s)
\end{tabular} & $\begin{array}{l}\text { UTAUT } \\
\text { Model }\end{array}$ \\
\hline 36 & System & $\begin{array}{lr}\text { Lack } & \text { of } \\
\text { Theoretical } & \text { bases } \\
\& & \text { inter- } \\
\text { organizational } \\
\text { relationships. }\end{array}$ & $\begin{array}{|lr|}\text { Andreas } & \text { I. } \\
\text { Nicolaou, 2008 }\end{array}$ & $\begin{array}{l}\text { 1) This research note utilizes recent } \\
\text { research findings that bear on the } \\
\text { effectiveness of the implementation and use } \\
\text { of ERPS in business organizations and } \\
\text { extends these findings in the inter- } \\
\text { organizational context. }\end{array}$ & ERPS & $\begin{array}{l}\text { The } \\
\text { economic } \\
\text { theory of } \\
\text { complemen } \\
t \\
\text { arity and } \\
\text { real options } \\
\text { theory from } \\
\text { finance. }\end{array}$ \\
\hline 37 & System & $\begin{array}{l}\text { Lack of } \\
\text { Challenges. }\end{array}$ & $\begin{array}{l}\text { Jim Odhiambo } \\
\text { Otieno } \\
2011\end{array}$ & $\begin{array}{l}\text { 1) ERP implementation and upgrade is } \\
\text { influenced by existing contextual factors - } \\
\text { national and organizational. } \\
\text { 2) The study provides practical guidelines } \\
\text { to practitioners on ERP implementation and } \\
\text { upgrade based on the experience of the case } \\
\text { study organizations and the } \\
\text { ERP consultants interviewed. }\end{array}$ & $\begin{array}{l}\text { Empirical } \\
\text { ERP } \\
\text { Implementati } \\
\text { on Model } \\
\text { (EEIM)and } \\
\text { the Upgrade } \\
\text { Decision } \\
\text { Model } \\
\text { (UDM) } \\
\end{array}$ & $\begin{array}{l}\text { BPR and } \\
\text { Parr and } \\
\text { Shank's } \\
\text { model } \\
\text { (PPM) }\end{array}$ \\
\hline 38 & System & $\begin{array}{l}\text { Lack of social } \\
\text { factors. }\end{array}$ & $\begin{array}{l}\text { 1.Man-Kit } \\
\text { Chang, } \\
\text { 2.Waiman } \\
\text { Cheung, } \\
\text { 3.Chun-Hung } \\
\text { Cheng and } \\
\text { 4. Jeff H.Y. } \\
\text { Yeung, 2008 } \\
\end{array}$ & $\begin{array}{l}\text { 1) Social factors are the most significant } \\
\text { determinant affecting the ERP system } \\
\text { usage. } \\
\text { 2) Other factors such as compatibility and } \\
\text { near-term consequences are also significant. } \\
\text { 3) Propose some important managerial } \\
\text { implications in connection to promoting the } \\
\text { usage. }\end{array}$ & $\begin{array}{l}\text { An empirical } \\
\text { study }\end{array}$ & $\begin{array}{l}\text { Conceptual } \\
\text { Model(deri } \\
\text { ved from } \\
\text { Triandis } \\
\text { framework) } \\
\& \\
\text { regression } \\
\text { analysis. }\end{array}$ \\
\hline 39 & System & $\begin{array}{l}\text { Lack of study } \\
\text { findings for IS. }\end{array}$ & $\begin{array}{l}\text { Princely Ifinedo, } \\
\text { Birger Rapp, } \\
\text { Airi Ifinedo, } \\
\text { Klas Sundberg, } \\
2010\end{array}$ & $\begin{array}{l}\text { 12. SEM results showed that five out of the } \\
\text { six hypotheses have significant, positive } \\
\text { associations. } \\
\text { 2) The pertinence of the study's findings } \\
\text { for IS success evaluation as well as its } \\
\text { implications for practice and research are } \\
\text { discussed. }\end{array}$ & $\begin{array}{l}\text { SEM } \\
\text { (Structural } \\
\text { Equation } \\
\text { Modeling) }\end{array}$ & $\begin{array}{l}\text { Six } \\
\text { hypotheses }\end{array}$ \\
\hline 40 & System & $\begin{array}{l}\text { Lack of decision- } \\
\text { support benefits } \\
\text { from an ERP } \\
\text { system. }\end{array}$ & \begin{tabular}{lr|} 
Clyde r & W. \\
Holsapple, Mark \\
P. Sena, \\
2005
\end{tabular} & $\begin{array}{l}\text { 1) It provides insights into the decision- } \\
\text { support benefits of ERP systems. } \\
\text { 2) The study also examines relationships } \\
\text { between the importances of various } \\
\text { objectives in ERP planning. } \\
\text { 3) The subsequent realization of decision- } \\
\text { support benefits from an ERP system. }\end{array}$ & DSS & $\begin{array}{l}\text { ERP } \\
\text { System } \\
\text { Adopters }\end{array}$ \\
\hline 41 & System & $\begin{array}{l}\text { Lack of technology } \\
\text { implementation. }\end{array}$ & $\begin{array}{l}\text { 1. Kwasi } \\
\text { Amoako- } \\
\text { Gyampah, } \\
\text { 2.A.F. Salam, } \\
2004\end{array}$ & $\begin{array}{l}\text { Empirical and theoretical support for the use } \\
\text { of managerial interventions, such as training } \\
\text { and communication, to influence } \\
\text { the acceptance of technology. }\end{array}$ & $\begin{array}{l}\text { Technology } \\
\text { Acceptance } \\
\text { Model (TAM } \\
\text { ). }\end{array}$ & $\begin{array}{l}\text { Shared } \\
\text { beliefs; } \\
0 \text { Training } \\
\& \\
\text { Communic } \\
\text { ation }\end{array}$ \\
\hline
\end{tabular}




\begin{tabular}{|c|c|c|c|c|c|c|}
\hline 42 & System & $\begin{array}{l}\text { Lack of decision } \\
\text { making approach. }\end{array}$ & $\begin{array}{l}\text { E. Ertugrul } \\
\text { Karsak, } \\
\text { C. Okan Özogul } \\
2009\end{array}$ & $\begin{array}{l}\text { 1) The presented methodology appears as a } \\
\text { sound investment decision making tool for } \\
\text { ERP Systems as well as other information } \\
\text { systems. } \\
\text { 2) The potential use of the proposed } \\
\text { decision framework is illustrated through an } \\
\text { application. }\end{array}$ & QFD & $\begin{array}{l}\text { Fuzzy } \\
\text { linear } \\
\text { regression } \\
\text { and zero- } \\
\text { on } \\
\text { e goal } \\
\text { program } \\
\text { ming. }\end{array}$ \\
\hline 43 & System & $\begin{array}{l}\text { Lack of Adoption } \\
\text { on firm. }\end{array}$ & $\begin{array}{l}\text { 1. Juha-Pekka } \\
\text { Kallunkiz. } 1 . \\
\text { 2. Erkki K. K. } \\
\text { Laitinen', } \\
\text { 3.Hanna } \\
\text { Silvolas. } 2011\end{array}$ & $\begin{array}{l}\text { 1) Formal types of management control } \\
\text { systems act as intervening variables } \\
\text { mediating the positive lagged effect between } \\
\text { enterprise systems adoption and non- } \\
\text { financial performance. } \\
\text { 2) Find a significant relationship between } \\
\text { non-financial and financial firm } \\
\text { performance. }\end{array}$ & Survey data. & $\begin{array}{l}\text { Empirical } \\
\text { Analyses }\end{array}$ \\
\hline 44 & System & $\begin{array}{l}\text { Lack of } \\
\text { ES(Enterprise-wide } \\
\text { Systems) } \\
\text { organizational } \\
\text { issues. }\end{array}$ & $\begin{array}{l}\text { John Ward, } \\
\text { Christopher } \\
\text { Hemingway, } \\
\text { Elizabeth Danie. } \\
2005\end{array}$ & $\begin{array}{l}\text { 1) The findings from the case studies } \\
\text { suggest that the framework can help } \\
\text { understand how different approaches to } \\
\text { managing ES implementations both address. } \\
\text { 2) It influences the behaviours of key } \\
\text { interest groups and hence the achievement } \\
\text { of the benefits expected from the } \\
\text { investment. }\end{array}$ & Framework. & $\begin{array}{l}\text { CRM \& } \\
\text { ERP } \\
\text { Software } \\
\text { Packages. }\end{array}$ \\
\hline 45 & System & $\begin{array}{l}\text { Lack of usage \& } \\
\text { usefulness (of the } \\
\text { system). }\end{array}$ & $\begin{array}{l}1 \\
\text { Amoako- Kwasi } \\
\text { Gyampah. } \\
2007\end{array}$ & $\begin{array}{l}\text { 1) The results indicate that users } \\
\text { perception of the perceived } \\
\text { usefulness, ease of use of the } \\
\text { technology, and the users' level of } \\
\text { intrinsic involvement all affect their } \\
\text { intention to use the technology. }\end{array}$ & Mail survey & $\begin{array}{l}\text { Users }^{\prime} \\
\text { Perceptions }\end{array}$ \\
\hline 46 & System & $\begin{array}{l}\text { Lack of } \\
\text { Organizational } \\
\text { citizenship } \\
\text { behaviors (OCBs). }\end{array}$ & $\begin{array}{l}\text { Cheolho Yoon, } \\
2009\end{array}$ & $\begin{array}{l}\text { 1) It provides strategic insights for } \\
\text { successfully managing ERP systems by } \\
\text { identifying the effects of organizational } \\
\text { citizenship behaviors in ERP context. }\end{array}$ & SEM & $\begin{array}{l}\text { Research } \\
\text { Model }\end{array}$ \\
\hline 47 & System & $\begin{array}{l}\text { Lack of Security } \\
\text { and reporting } \\
\text { issues. }\end{array}$ & $\begin{array}{l}\text { Daniel E. } \\
\text { O'Leary } \\
\text { M. Lynne } \\
\text { Markus, } \\
\text { BentleyCollege, } \\
2005\end{array}$ & $\begin{array}{l}\text { 1) This paper investigates Microsoft's } \\
\text { Enterprise Resource Planning (ERP) System } \\
\text { implementation. } \\
\text { 2) Risks and controls investigated include } \\
\text { network exposures, data access, information } \\
\text { disclosures, periodic lockouts and warnings } \\
\text { and built-in controls. }\end{array}$ & $\begin{array}{l}\text { SAP, Data } \\
\text { Warehousing } \\
\text { Tools }\end{array}$ & $\begin{array}{l}\text { FinWeb \& } \\
\text { MAP99 }\end{array}$ \\
\hline 48 & System & $\begin{array}{l}\text { Lack of sustained } \\
\text { innovation. }\end{array}$ & \begin{tabular}{ll|} 
Thongchai & \\
Srivardhana, \\
Suzanne \\
Pawlowski, \\
2007
\end{tabular} & $\begin{array}{l}\text { 1) The model highlights areas where } \\
\text { active management has potential to } \\
\text { enhancethe capabilities of a firm } \\
\text { 2) for sustained innovation of its business } \\
\text { processes. }\end{array}$ & $\begin{array}{l}\text { Theoretical } \\
\text { framework }\end{array}$ & Model \\
\hline 49 & System & $\begin{array}{l}\text { Lack of } \\
\text { Behavioral aspects } \\
\text { of ERP systems } \\
\text { adoption. }\end{array}$ & $\begin{array}{l}\text { Yujong Hwang, } \\
\text { Delvin Grant, } \\
2011\end{array}$ & $\begin{array}{l}\text { 1) The results indicate that low power } \\
\text { distance and high uncertainty } \\
\text { avoidance cultural orientation influence } \\
\text { general CSE. } \\
\text { 2) Uncertainty avoidance positively } \\
\text { influences ease of use of ERP systems. }\end{array}$ & $\begin{array}{l}\text { An online } \\
\text { survey } \\
\text { methodology }\end{array}$ & $\begin{array}{l}\text { Research } \\
\text { Model }\end{array}$ \\
\hline 50 & System & $\begin{array}{l}\text { Lack of System } \\
\text { performance. }\end{array}$ & $\begin{array}{l}\text { 1.Wen-Hsien tsai, } \\
\text { 2. Michael J. } \\
\text { Shaw, } \\
\text { 3. Yi-Wen Fan, } \\
\text { 4.Jau-Yang Liu, } \\
\text { 5. Kuen-Chang } \\
\text { Lee, } \\
\text { 6. Hui-Chiao Chen } \\
\text { 2011 }\end{array}$ & $\begin{array}{l}\text { 1) The results reveal a significant causal } \\
\text { relationship between system providers, } \\
\text { implementation consultants } \\
\text { and project management, and project to } \\
\text { system performance. }\end{array}$ & $\begin{array}{l}\text { SERVQUAL } \\
\text { Instrument. }\end{array}$ & $\begin{array}{l}\text { SEM } \\
\text { (Structural } \\
\text { Equation } \\
\text { Modeling) }\end{array}$ \\
\hline 51 & System & $\begin{array}{ll}\text { Lack } & \text { of } \\
\text { Interdependency }\end{array}$ & \begin{tabular}{ll|} 
Oana & Velcu \\
2010 &
\end{tabular} & $\begin{array}{l}\text { 1) Investigated the association between strategic } \\
\text { alignment, management of ERP projects, } \\
\text { business process changes, and the business } \\
\text { performance of ERP systems. } \\
\text { 2) The strategic alignment concept was found to } \\
\text { have a central role in the Results Model. } \\
\text { 3) Results showed that the more the ERP system } \\
\text { strategy was aligned with the business strategy, } \\
\text { the more likely } \\
\text { that the ERP project was completed on budget } \\
\text { and on time. }\end{array}$ & $\begin{array}{l}\text { Structural } \\
\text { Model }\end{array}$ & Language \\
\hline
\end{tabular}

Table-1 : Barriers of ERP (identified through literature survey). 
Table 2: ERP and AHP Barriers identified through literature review :

\begin{tabular}{|c|c|c|c|c|c|c|}
\hline $\begin{array}{l}S . \\
N\end{array}$ & $\begin{array}{l}\text { Category } \\
\text { / } \\
\text { Class }\end{array}$ & $\begin{array}{l}\text { Barrier( } \\
\text { s) }\end{array}$ & $\begin{array}{l}\text { Name of } \\
\text { author \&year }\end{array}$ & Key research findings & $\begin{array}{l}\text { Methodology } \\
\text { used }\end{array}$ & $\begin{array}{l}\text { Tool(s) } \\
\text { used }\end{array}$ \\
\hline 1. & Risk & $\begin{array}{l}\text { Lack } \\
\text { ofcooper } \\
\text { ation } \\
\text { and } \\
\text { commit } \\
\text { ment of } \\
\text { ERP } \\
\text { users } \\
\text { and } \\
\text { manager } \\
\mathrm{s}\end{array}$ & $\begin{array}{l}\text { J.L. Salmeron, } \\
\text { C. Lopez } \\
2010\end{array}$ & $\begin{array}{l}\text { 1.The most critical stage in ERP } \\
\text { maintenance is the first phase, } \\
\text { which receives, identifies, } \\
\text { classifies and ranks the software } \\
\text { modification. } \\
\text { 2. The findings of this study can } \\
\text { also help the professional to } \\
\text { achieve effective risk management } \\
\text { in the whole ERP maintenance. }\end{array}$ & MCDM & AHP \\
\hline 2. & $\begin{array}{l}\text { Applicati } \\
\text { ons } \\
\text { (factors)/ } \\
\text { Methods/ } \\
\text { Materials }\end{array}$ & $\begin{array}{l}\text { Lack of } \\
\text { project } \\
\text { manage } \\
\text { ment / } \\
\text { Publishe } \\
\text { rs. }\end{array}$ & $\begin{array}{l}\text { N. } \\
\text { Subramanian, } \\
\text { R. } \\
\text { Ramanathan, } \\
2012\end{array}$ & $\begin{array}{l}\text { 1. Significant research gap exists } \\
\text { in the application of AHP in the } \\
\text { areas of forecasting, layout of } \\
\text { facilities and managing stocks. } \\
\text { 2.Develops a framework for } \\
\text { identifying the decision areas. }\end{array}$ & $\begin{array}{l}\text { Observations } \\
\text { Tables. }\end{array}$ & AHP \\
\hline 3. & $\begin{array}{l}\text { Framewo } \\
\text { rk }\end{array}$ & $\begin{array}{l}\text { Lack of } \\
\text { feasibilit } \\
y\end{array}$ & $\begin{array}{l}\text { C.-C. Wei et } \\
\text { al. } \\
2005\end{array}$ & $\begin{array}{l}\text { 1. Found out means and } \\
\text { fundamental objectives for the } \\
\text { framework of ERP system. } \\
\text { 2. These objectives also indicate } \\
\text { how outcomes should be } \\
\text { measured and what key points } \\
\text { should be considered in the } \\
\text { decision process. }\end{array}$ & $\begin{array}{l}\text { ERP System } \\
\text { framework }\end{array}$ & AHP \\
\hline 4. & $\begin{array}{l}\text { Factors/ } \\
\text { system }\end{array}$ & $\begin{array}{l}\text { Lack of } \\
\text { consiste } \\
\text { ncy may } \\
\text { arise in } \\
\text { AHP }\end{array}$ & $\begin{array}{l}\text { J.L. Salmeron, } \\
\text { I. Herrero, } \\
2005\end{array}$ & $\begin{array}{l}\text { 1. Multiple choices were } \\
\text { contemplated. } \\
\text { 2. It provides a method for ranking } \\
\text { critical success factors. }\end{array}$ & AHP & $\begin{array}{l}\text { SAP } \\
\text { R/3 }\end{array}$ \\
\hline 5. & Software & $\begin{array}{l}\text { Lack of } \\
\text { generic } \\
\text { methodo } \\
\text { logy }\end{array}$ & $\begin{array}{l}\text { A.S. Jadhav, } \\
\text { R.M. Sonar, } \\
2009\end{array}$ & $\begin{array}{l}\text { (1) analytic hierarchy process has } \\
\text { been widely used for evaluation of } \\
\text { the software packages, (2) there is } \\
\text { lack of a common list of generic } \\
\text { software evaluation criteria and its } \\
\text { meaning, and } \\
\text { (3) there is need to develop a } \\
\text { framework comprising of software } \\
\text { selection methodology, evaluation } \\
\text { technique, evaluation criteria, and } \\
\text { system to assist decision makers in } \\
\text { software selection. }\end{array}$ & $\begin{array}{l}\text { Selection of } \\
\text { software } \\
\text { framework,st } \\
\text { eps. }\end{array}$ & $\begin{array}{l}\text { SimSel } \\
\text { ect }\end{array}$ \\
\hline 6. & Software & $\begin{array}{l}\text { Lack of } \\
\text { decision } \\
\text { making }\end{array}$ & $\begin{array}{l}\text { A.S. Jadhav, } \\
\text { R.M. Sonar, } \\
2011\end{array}$ & $\begin{array}{l}\text { This study provides conceptual } \\
\text { understanding of all aspects } \\
\text { related to the software selection } \\
\text { such as (i) methodology } \\
\text { describing factors and issues } \\
\text { (ii) software evaluation criteria } \\
\text { (iii) software evaluation } \\
\text { techniques. }\end{array}$ & $\begin{array}{l}\text { (i) generic } \\
\text { methodology } \\
\text { for software } \\
\text { selection, } \\
\text { (ii) software } \\
\text { evaluation } \\
\text { criteria }\end{array}$ & $\begin{array}{l}\text { hybrid } \\
\text { knowle } \\
\text { dge } \\
\text { based } \\
\text { system } \\
\text { (HKBS } \\
\text { ) } \\
\text { approa } \\
\text { ch }\end{array}$ \\
\hline
\end{tabular}




\begin{tabular}{|c|c|c|c|c|c|c|}
\hline 7. & Model & $\begin{array}{l}\text { Lack of } \\
\text { inconsist } \\
\text { ent } \\
\text { problem } \\
\mathrm{s} \text { in } \\
\text { AHP }\end{array}$ & $\begin{array}{l}\text { Tsung-Han } \\
\text { Changa, } \\
\text { Shu-Chen } \\
\text { Hsub,Tien- } \\
\text { Chin Wangc, } \\
\text { Chao-Yen } \\
\text { Wud,2012 }\end{array}$ & $\begin{array}{l}\text { 1) Improves the efficiency of } \\
\text { pairwise comparison compared } \\
\text { with the traditional AHP. } \\
\text { 2) The possible occurrence ratings } \\
\text { of success or failure outcome } \\
\text { amongst decision } \\
\text { makers. }\end{array}$ & $\begin{array}{l}\text { MCDM with } \\
\text { Incomplete } \\
\text { Linguistic } \\
\text { Preference } \\
\text { Relations } \\
\text { (InLinPreRa) }\end{array}$ & AHP \\
\hline 8. & $\begin{array}{l}\text { Construc } \\
\text { tion }\end{array}$ & $\begin{array}{l}\text { Lack of } \\
\text { activitie } \\
\text { s/ } \\
\text { Criterias } \\
\text {. }\end{array}$ & $\begin{array}{l}\text { Mirian } \\
\text { PicininiMe' } \\
\text { xas a,n, } \\
\text { OsvaldoLuizG } \\
\text { onc-alves } \\
\text { Quelhas a, } \\
\text { HelderGomes } \\
\text { Costa 2012 }\end{array}$ & $\begin{array}{l}\text { 1)The study showed that the } \\
\text { financial, business and software } \\
\text { criteria were most important for } \\
\text { the respondents. } \\
\text { 2) The importance of the sub } \\
\text { criteria of each criteria group was } \\
\text { also presented to assist decision } \\
\text { makers when selecting ERP } \\
\text { system. }\end{array}$ & $\begin{array}{l}\text { ERP Systems } \\
\text { Selection } \\
\text { Criteria }\end{array}$ & AHP \\
\hline 9. & Review & $\begin{array}{l}\text { Lack of } \\
\text { rank } \\
\text { reversal, } \\
\text { some } \\
\text { theoretic } \\
\text { al } \\
\text { disputes. }\end{array}$ & $\begin{array}{l}\text { A. Ishizaka, } \\
\text { A. Labib, } \\
2011\end{array}$ & $\begin{array}{l}\text { It is discussed odeling, pair-wise } \\
\text { comparisons, judgement scales, } \\
\text { derivation methods, consistency } \\
\text { indices, incomplete } \\
\text { matrix, synthesis of the weights, } \\
\text { sensitivity analysis and group } \\
\text { decisions. } \\
\text { All have been important } \\
\text { areas of research in AHP. }\end{array}$ & $\begin{array}{l}\text { Modeling } \\
\text { \&other } \\
\text { MCDM } \\
\text { Methods. }\end{array}$ & AHP \\
\hline 10 & $\begin{array}{l}\text { Evaluati } \\
\text { on }\end{array}$ & $\begin{array}{l}\text { Lack of } \\
\text { judgeme } \\
\text { nts }\end{array}$ & $\begin{array}{l}\text { Lan Xu } \\
2012\end{array}$ & $\begin{array}{l}\text { 1) Presented ERP sandtable } \\
\text { simulation evaluation to discuss } \\
\text { how to make a } \\
\text { decision using AHP. } \\
\text { 2) Using this method can make } \\
\text { enterprises consider factors } \\
\text { influence operation of enterprise } \\
\text { adequately, including feedback } \\
\text { and dependence among the } \\
\text { factors. }\end{array}$ & $\begin{array}{l}\text { Sand table } \\
\text { method }\end{array}$ & AHP \\
\hline 11 & Ranking & $\begin{array}{l}\text { Lack of } \\
\text { alternati } \\
\text { ves of } \\
\text { the } \\
\text { decision }\end{array}$ & $\begin{array}{l}\text { T.L.Satty and } \\
\text { G.Hu } \\
1998\end{array}$ & $\begin{array}{l}\text { 1) EM (Eigenvalue Method) is the } \\
\text { only valid method for deriving the } \\
\text { priority vector from a pair wise } \\
\text { comparison matrix, particularly } \\
\text { when the matrix is inconsistent. }\end{array}$ & $\begin{array}{l}\text { Ranking by } \\
\text { EM Vector } \\
\text { Method. }\end{array}$ & AHP \\
\hline 12 & Review & $\begin{array}{l}\text { Lack of } \\
\text { results }\end{array}$ & $\begin{array}{l}\text { A.I. Nicolaou } \\
2004\end{array}$ & $\begin{array}{l}\text { 1) Presents contributions for both } \\
\text { the practice and research on ERP } \\
\text { system implementation } \\
\text { effectiveness. }\end{array}$ & $\begin{array}{l}\text { A case study } \\
\text { methodology }\end{array}$ & $\begin{array}{l}\text { Post } \\
\text { imple } \\
\text { mentati } \\
\text { on } \\
\text { review } \\
\text { (PIR) }\end{array}$ \\
\hline 13 & Analysis & $\begin{array}{l}\text { Lack of } \\
\text { use of } \\
\text { the 9- } \\
\text { point } \\
\text { scale. }\end{array}$ & $\begin{array}{l}\text { C. Macharis et } \\
\text { al. } \\
2004\end{array}$ & $\begin{array}{l}\text { Recommendations are formulated } \\
\text { to integrate into PROMETHEE a } \\
\text { number of useful AHP features. } \\
\text { 2) Suggests that future academic } \\
\text { research should focus on } \\
\text { comparative assessments of the } \\
\text { relative strengths and weaknesses } \\
\text { of alternative MCA approaches. }\end{array}$ & $\begin{array}{l}\text { Preference } \\
\text { Ranking } \\
\text { Organisation } \\
\text { MeTHod for } \\
\text { Enrichment } \\
\text { Evaluations } \\
\text { (PROMETH } \\
\text { EE) . }\end{array}$ & AHP \\
\hline 14 & $\begin{array}{l}\text { Algorith } \\
\mathrm{m}\end{array}$ & $\begin{array}{l}\text { Lack of } \\
\text { decision } \\
\text { making }\end{array}$ & $\begin{array}{l}\text { S. } \\
\text { Mahmoodzade } \\
\text { h, J. Shahrabi, }\end{array}$ & $\begin{array}{l}\text { 1) A simple approach to assess } \\
\text { alternative projects and help } \\
\text { decision maker to select the best }\end{array}$ & $\begin{array}{l}\text { TOPSIS } \\
\text { Technique/ } \\
\text { Algorithm. }\end{array}$ & $\begin{array}{l}\text { Fuzzy } \\
\text { AHP }\end{array}$ \\
\hline
\end{tabular}




\begin{tabular}{|c|c|c|c|c|c|c|}
\hline & & & $\begin{array}{l}\text { M. Pariazar, } \\
\text { and } \text { M. S. } \\
\text { Zaeri } \\
2007\end{array}$ & $\begin{array}{l}\text { one. } \\
\text { 2) Reduce or eliminate assessment } \\
\text { bias in pairwise comparison } \\
\text { process. } \\
\text { 3) To support project selection } \\
\text { decisions. }\end{array}$ & & \\
\hline 15 & System & $\begin{array}{l}\text { Lack of } \\
\text { innovati } \\
\text { ons }\end{array}$ & $\begin{array}{l}\text { Injazz J.Chen } \\
2001\end{array}$ & $\begin{array}{l}\text { 1) Several critical planning } \\
\text { issues are resolved. } \\
\text { 2) Study also identifies new } \\
\text { windows of opportunities and } \\
\text { challenges facing companies. }\end{array}$ & Analysis & $\begin{array}{l}\text { ERP } \\
\text { System }\end{array}$ \\
\hline 16 & $\begin{array}{l}\text { Compari } \\
\text { son }\end{array}$ & $\begin{array}{l}\text { Lack of } \\
\text { facts }\end{array}$ & $\begin{array}{l}\text { P. } \\
\text { KORHONEN } \\
\text { AND H. } \\
\text { TOPDAGI } \\
2003\end{array}$ & $\begin{array}{l}\text { 1) AHP is able to estimate the } \\
\text { reasonable utility values for } \\
\text { objects surprisingly well. } \\
\text { 2) The origin separating utility } \\
\text { and disutility scales was estimated } \\
\text { as well. }\end{array}$ & $\begin{array}{l}\text { Ratio-scale } \\
\text { AHP } \\
\text { Analysis }\end{array}$ & AHP \\
\hline 17 & $\begin{array}{l}\text { Selection } \\
\text { / Evaluati } \\
\text { on }\end{array}$ & $\begin{array}{l}\text { Lack of } \\
\text { certain } \\
\text { choices }\end{array}$ & $\begin{array}{l}\text { ic, I,Lalic, B. } \\
2009\end{array}$ & $\begin{array}{l}\text { 1) This tool helps us with } \\
\text { simulating project importance } \\
\text { based on changes in perception } \\
\text { of the criteria. } \\
\text { 2) AHP can dramatically } \\
\text { improve the process of developing } \\
\text { project proposals. } \\
\text { 3) Its biggest strength is } \\
\text { systematic approach in several } \\
\text { steps. }\end{array}$ & $\begin{array}{l}\text { MS EXCEL } \\
\text { SOFTWARE } \\
\& \\
\text { SIMULATIO } \\
\mathrm{N}\end{array}$ & AHP \\
\hline 18 & $\begin{array}{l}\text { Risk- } \\
\text { based }\end{array}$ & $\begin{array}{l}\text { Lack of } \\
\text { risk } \\
\text { attitude }\end{array}$ & $\begin{array}{l}\text { Solomon } \\
\text { Tesfamariam, } \\
\text { Rehan Sadiq } \\
2006\end{array}$ & $\begin{array}{l}\text { 1) The traditional AHP is } \\
\text { modified to fuzzy AHP using } \\
\text { fuzzy arithmetic } \\
\text { operations. } \\
\text { 2) The methodology of the } \\
\text { proposed technique is built on a } \\
\text { hypothetical } \\
\text { example. }\end{array}$ & MCDM & F-AHP \\
\hline 19 & $\begin{array}{l}\text { Performa } \\
\text { nce }\end{array}$ & $\begin{array}{l}\text { lack of } \\
\text { perform } \\
\text { ance } \\
\text { meaasur } \\
\text { es. }\end{array}$ & $\begin{array}{l}\text { Wen-Hsien } \\
\text { Tsai*, } \\
\text { Ping-Yu } \\
\text { Hsu*, } \\
\text { Yi-Wen } \\
\text { Fan**, } \\
\text { Jun-Der Leu* } \\
2003\end{array}$ & $\begin{array}{l}\text { 1) Presented an AHP approach to } \\
\text { achieving the relative importance } \\
\text { weights of ERP performance } \\
\text { measures. } \\
\text { 2) A company can select the } \\
\text { specific dimensions and measures } \\
\text { according to the goals of ERP } \\
\text { systems and the context of the } \\
\text { company. }\end{array}$ & $\begin{array}{l}\text { Two-stage } \\
\text { approach }\end{array}$ & AHP \\
\hline 20 & $\begin{array}{l}\text { Case } \\
\text { study }\end{array}$ & $\begin{array}{l}\text { Lack of } \\
\text { objectiv } \\
\mathrm{e} \\
\text { function } \\
\mathrm{s} \\
\text { \&evalua } \\
\text { tion } \\
\text { factors. }\end{array}$ & $\begin{array}{l}\text { M. } \\
\text { Marufuzzaman } \\
\text { K.B. Ahsan } \\
\text { and K. Xing } \\
2009\end{array}$ & $\begin{array}{l}\text { 1) This selection process helps } \\
\text { the manager to select a supplier } \\
\text { from a dynamic environment. } \\
\text { 2) Another important finding is } \\
\text { that the proposed model is more } \\
\text { reflecting the relation of how the } \\
\text { selection criteria affect the } \\
\text { selected suppliers and at the same } \\
\text { time what is more important for } \\
\text { the suppliers among the selection } \\
\text { criteria. }\end{array}$ & MCDM & AHP \\
\hline 21 & $\begin{array}{l}\text { Case } \\
\text { study }\end{array}$ & $\begin{array}{l}\text { Lack of } \\
\text { flexibilit }\end{array}$ & $\begin{array}{l}\text { Carlos Parra- } \\
\text { López, }\end{array}$ & $\begin{array}{l}\text { 1) Results for this case study } \\
\text { show a }\end{array}$ & $\begin{array}{l}\text { AHP- } \\
\text { extended }\end{array}$ & AHP \\
\hline
\end{tabular}




\begin{tabular}{|c|c|c|c|c|c|c|}
\hline & & $\begin{array}{l}\text { y } \\
\text { \&previo } \\
\text { us } \\
\text { specific } \\
\text { data, } \\
\text { hard } \\
\text { data. }\end{array}$ & $\begin{array}{l}\text { Javier } \\
\text { Calatrava- } \\
\text { Requena, } \\
\text { Tomás de- } \\
\text { Haro-Giménez } \\
2007\end{array}$ & $\begin{array}{l}\text { greater global performance of } \\
\text { organic and integrated agriculture } \\
\text { despite differences in the } \\
\text { ideological tendencies of the } \\
\text { experts. } \\
\text { 2) Thus providing a scientific } \\
\text { basis for endorsing institutional } \\
\text { and social support for the } \\
\text { promotion and implementation of } \\
\text { these farming techniques. } \\
\text { 3) Some conflictive issues, } \\
\text { however, have been detected, } \\
\text { especially in areas related to } \\
\text { environmental performance. } \\
\text { 4) Further research on the } \\
\text { controversial topics is desirable } \\
\text { for clarification. }\end{array}$ & methodology & \\
\hline 22 & $\begin{array}{l}\text { Note / } \\
\text { Procedur } \\
\text { e. }\end{array}$ & $\begin{array}{l}\text { Lack of } \\
\text { problem } \\
\text { with } \\
\text { inconsist } \\
\text { ency.pro } \\
\text { bloblem } \\
\text { proble }\end{array}$ & $\begin{array}{l}\text { H. Chao et al. } \\
2004 .\end{array}$ & $\begin{array}{l}\text { 1) It is suggested that decision- } \\
\text { makers still use the comparison } \\
\text { matrix of Saaty. } \\
\text { 2) Numerical examples are } \\
\text { included to illustrate the findings. } \\
\text { 3) As a result, it is concluded that } \\
\text { the } \\
\text { decision-makers should use the } \\
\text { comparison matrix of Saaty. } \\
\text { nnnnnnn }\end{array}$ & $\begin{array}{l}\text { Comparison } \\
\text { matrix(Satty) }\end{array}$ & AHP \\
\hline 23 & Review & $\begin{array}{l}\text { Lack of } \\
\text { degree } \\
\text { of } \\
\text { change. }\end{array}$ & $\begin{array}{l}\text { John Gunson, } \\
\text { Jean-Paul de } \\
\text { Blasis } \\
2003\end{array}$ & $\begin{array}{l}\text { 1) The report findings highlight } \\
\text { success factors(in order of } \\
\text { importance) - user involvement, } \\
\text { executive management support, } \\
\text { clear statement of requirements } \\
\text {,proper planning, realistic } \\
\text { expectations, smaller project } \\
\text { milestones, competent staff, } \\
\text { ownership, clear vision and } \\
\text { objectives, hard-working focused } \\
\text { staff, other. } \\
\text { 2) Another finding was that } \\
\text { project failures were on the } \\
\text { increase in } 1995 \text { compared to } \\
\text { 1990 or } 1985 \text {. }\end{array}$ & $\begin{array}{l}\text { ERP } \\
\text { Solutions }\end{array}$ & $\begin{array}{l}\text { Modul } \\
\text { es } \\
\text { Enhanc } \\
\text { ed } \\
\text { ERP } \\
\text { Web }\end{array}$ \\
\hline 24 & $\begin{array}{l}\text { Experim } \\
\text { ent }\end{array}$ & Lack of & $\begin{array}{l}\text { James R. } \\
\text { Langenbrunne } \\
\text { r et al. } \\
2010\end{array}$ & $\begin{array}{l}\text { 1) A method of information } \\
\text { integration is illustrated. } \\
\text { 2) (AHP) is used to determine } \\
\text { weights for two models and two } \\
\text { experimental data sets, by forming } \\
\text { all possible pair-wise comparisons } \\
\text { between model output and } \\
\text { experimental data. }\end{array}$ & Modeling & AHP \\
\hline $\begin{array}{l}25 \\
.\end{array}$ & $\begin{array}{l}\text { Software } \\
\text { / } \\
\text { Perspecti } \\
\text { ve }\end{array}$ & $\begin{array}{l}\text { Lack of } \\
\text { interrela } \\
\text { ted } \\
\text { measure } \\
\text { s }\end{array}$ & $\begin{array}{l}\text { Michael } \\
\text { Rosemann, } \\
\text { Jens Wiese } \\
2000\end{array}$ & $\begin{array}{l}\text { 1) Information concerning this } \\
\text { perspective as well as concerning } \\
\text { the other perspectives is mainly } \\
\text { based on non-financial measures. } \\
\text { 2) The final objective is to design } \\
\text { a reference Balanced Scorecard. } \\
\text { 3)As far as possible the Balanced } \\
\text { Scorecard functionality within } \\
\text { ERP software will be used to }\end{array}$ & $\begin{array}{l}\text { BSC(Balance } \\
\text { d Score } \\
\text { Card) } \\
\text { approach. }\end{array}$ & $\begin{array}{l}\text { ERP } \\
\text { Softwa } \\
\text { re }\end{array}$ \\
\hline
\end{tabular}




\begin{tabular}{|c|c|c|c|c|c|c|}
\hline & & & & realize an IT-based solution. & & \\
\hline 26 & Analysis & $\begin{array}{l}\text { Lack of } \\
\text { preparin } \\
\mathrm{g} \text { the } \\
\text { data for } \\
\text { the } \\
\text { analysis. }\end{array}$ & $\begin{array}{l}\text { J. Jablonsky } \\
2007\end{array}$ & $\begin{array}{l}\text { 1) This paper discusses the } \\
\text { possibility of using an AHP model } \\
\text { with interval pairwise } \\
\text { comparisons for the evaluation } \\
\text { and classification of efficient } \\
\text { units, and compares the results } \\
\text { with super-efficiency DEA scores } \\
\text { / models. } \\
\text { 2) Several real-life economic } \\
\text { applications will serve as } \\
\text { background for numerical } \\
\text { experiments. } \\
\text { 3) The proposed approach is } \\
\text { applied to assess the efficiency of } \\
\text { pension funds in the Czech } \\
\text { Republic. }\end{array}$ & $\begin{array}{l}\text { data } \\
\text { envelopment } \\
\text { analysis } \\
\text { (DEA) } \\
\text { approach. }\end{array}$ & $\begin{array}{l}\text { AHP - } \\
\text { interva } \\
1 \text { AHP } \\
\text { Model }\end{array}$ \\
\hline 27 & System & $\begin{array}{l}\text { Lack of } \\
\text { some } \\
\text { aspects. }\end{array}$ & $\begin{array}{l}\text { Manouchehr } \\
\text { Behboudi Asl } \\
\text { et al. } \\
2012\end{array}$ & $\begin{array}{l}\text { 1) Using Delphi method, the } \\
\text { following } \\
\text { factors: cost, software quality, } \\
\text { vendor and software capability } \\
\text { were identified as the main factors } \\
\text { which should be considered by the } \\
\text { organizations. } \\
\text { 2) These criteria were, then, } \\
\text { ranked using Shannon Entropy } \\
\text { technique and the vendor was } \\
\text { identified as the most important } \\
\text { criterion. }\end{array}$ & $\begin{array}{l}\text { Shannon } \\
\text { Entropy } \\
\text { Algorithm } \\
\text { approach }\end{array}$ & $\begin{array}{l}\text { Delphi } \\
\text { method } \\
\text { process }\end{array}$ \\
\hline 28 & System & $\begin{array}{l}\text { Lack of } \\
\text { appropri } \\
\text { ate } \\
\text { system }\end{array}$ & $\begin{array}{l}\text { Ottar Bakås1, } \\
\text { Anita } \\
\text { Romsdal2 and } \\
\text { Erlend Alfnes2 } \\
2007\end{array}$ & $\begin{array}{l}\text { 1) The final output for the } \\
\text { organisation is a choice of ERP } \\
\text { system and vendor that ensures } \\
\text { strategic fit and functional } \\
\text { integration in the organisation. } \\
\text { 2) The methodology was } \\
\text { successfully developed and } \\
\text { implemented in a Norwegian case } \\
\text { company. }\end{array}$ & $\begin{array}{l}\text { Conceptual } \\
\text { framework, } \\
\text { Process } \\
\text { model and } \\
\text { Guidelines. }\end{array}$ & $\begin{array}{l}\text { ERP } \\
\text { System }\end{array}$ \\
\hline 29 & Method & $\begin{array}{l}\text { Lack of } \\
\text { relative } \\
\text { measure } \\
\text { ment. }\end{array}$ & $\begin{array}{l}\text { Thomas L. } \\
\text { Saaty } \\
1994\end{array}$ & $\begin{array}{l}\text { 1) This paper provides a detailed } \\
\text { discussion with references on the } \\
\text { fundamentals of the Analytic } \\
\text { Hierarchy Process and in } \\
\text { particular of relative measurement. } \\
\text { 2) It is shown that when there is } \\
\text { synergy due to the number of } \\
\text { elements the AHP can be used to } \\
\text { both preserve rank when it is } \\
\text { desired to preserve it and allow it } \\
\text { to reverse when it should reverse. }\end{array}$ & $\begin{array}{l}\text { EV(EigenVe } \\
\text { ctor) Method }\end{array}$ & AHP \\
\hline 30 & Method & $\begin{array}{l}\text { Lack of } \\
\text { effective } \\
\text { ness }\end{array}$ & $\begin{array}{l}\text { V.S.Lai et al. } \\
2002\end{array}$ & $\begin{array}{l}\text { 1) The experiment and survey } \\
\text { findings indicated that the AHP is } \\
\text { preferable to Delphi. } \\
\text { 2) The AHP to be more } \\
\text { conducive to consensus building } \\
\text { in group decision settings. }\end{array}$ & $\begin{array}{l}\text { TMulti- } \\
\text { media } \\
\text { authorising } \\
\text { systems(MA } \\
\text { Ss) }\end{array}$ & AHP \\
\hline 31 & Method & $\begin{array}{l}\text { Lack of } \\
\text { attribute } \\
\mathrm{s}\end{array}$ & $\begin{array}{l}\text { B.K. Mohanty, } \\
\text { N. Singh }\end{array}$ & $\begin{array}{l}\text { 1) This model of AHP gives the } \\
\text { solutions corresponding to the } \\
\text { various combination operators of }\end{array}$ & $\begin{array}{l}\text { Fuzzy } \\
\text { methodology } \\
\cdot\end{array}$ & AHP \\
\hline
\end{tabular}




\begin{tabular}{|c|c|c|c|c|c|c|}
\hline & & & 1994 & $\begin{array}{l}\text { the fuzzy relations. } \\
\text { 2) This leads to the ranking of the } \\
\text { attributes (at each hierarchy level) } \\
\text { in the AHP problem. }\end{array}$ & & \\
\hline 32 & Decision & $\begin{array}{l}\text { Lack of } \\
\text { moderat } \\
\mathrm{e} \\
\text { accurate } \\
\text { results. }\end{array}$ & $\begin{array}{l}C C \\
n n C\end{array}$ & $\begin{array}{l}\text { 1) AHP methodology based on } \\
\text { pairwise comparison element is a } \\
\text { suitable tool to estimate criteria } \\
\text { weighting which can get the } \\
\text { results in quantitative manners. } \\
\text { 2) It is suitable and flexible to } \\
\text { express the judgement of experts } \\
\text { in fuzzy numbers. } \\
\text { 3) The approach presented in this } \\
\text { paper is very useful. }\end{array}$ & $\begin{array}{l}\text { AHP } \\
\text { methodology } \\
\text { under fuzzy } \\
\text { environment }\end{array}$ & $\begin{array}{l}\text { MHD } \\
\text { M } \\
\text { (Multi } \\
\text { ple } \\
\text { Hierarc } \\
\text { hical } \\
\text { Decisi } \\
\text { on } \\
\text { Makin } \\
\text { g) }\end{array}$ \\
\hline 33 & $\begin{array}{l}\text { Supplier/ } \\
\text { Vendor }\end{array}$ & $\begin{array}{l}\text { Lack of } \\
\text { selection } \\
\text { of } \\
\text { vendor } \\
\text { with } \\
\text { time } \\
\text { axis }\end{array}$ & $\begin{array}{l}\underline{\text { Saroj Koul, }} \\
\underline{\text { Rakesh Verma }} \\
2011\end{array}$ & $\begin{array}{l}\text { 1) The research provides a } \\
\text { mathematical system that captures } \\
\text { the uncertainties associated with } \\
\text { human cognitive processes in } \\
\text { order to select the vendor. } \\
\text { 2) The findings of this study } \\
\text { provide meaningful and advanced } \\
\text { knowledge to decision makers by } \\
\text { demonstrating a simple, efficient } \\
\text { method to enhance the ability to } \\
\text { predict an appropriate vendor } \\
\text { period wise. }\end{array}$ & $\begin{array}{l}\text { fuzzy } \\
\text { analytic } \\
\text { hierarchy } \\
\text { process } \\
\text { (AHP) to } \\
\text { propose the } \\
\text { decision } \\
\text { model }\end{array}$ & AHP \\
\hline 34 & Supplier & $\begin{array}{l}\text { Lack of } \\
\text { current } \\
\text { grey } \\
\text { methodo } \\
\text { logy }\end{array}$ & $\begin{array}{l}\text { Davood } \\
\text { Golmohamma } \\
\text { di } \\
\text { Mahour } \\
\text { Mellat-Parast } \\
2012\end{array}$ & $\begin{array}{l}\text { 1) The findings suggest that the } \\
\text { proposed model provides more } \\
\text { consistent and reliable results } \\
\text { which are in line with managers' } \\
\text { ranking. } \\
\text { 2) Implications of the study to the } \\
\text { theory and practice and future } \\
\text { research have been outlined. }\end{array}$ & $\begin{array}{l}\text { An } \\
\text { integrated, } \\
\text { two-phase } \\
\text { model is } \\
\text { proposed } \\
\text { which } \\
\text { integrates the } \\
\text { fuzzy } \\
\text { pairwise } \\
\text { comparison } \\
\text { with a grey } \\
\text { relational } \\
\text { analysis. }\end{array}$ & $\begin{array}{l}\text { Decisi } \\
\text { on } \\
\text { making } \\
\text { model }\end{array}$ \\
\hline 35 & $\begin{array}{l}\text { Safety } \\
\text { Mgmt/ } \\
\text { Evaluati } \\
\text { on }\end{array}$ & Lack of & $\begin{array}{l}\text { Metin } \\
\text { Dağdeviren } \\
\text { İhsan Yüksel } \\
2008\end{array}$ & $\begin{array}{l}\text { 1) In this study, a fuzzy AHP } \\
\text { approach is proposed to determine } \\
\text { the level of faulty behavior risk } \\
\text { (FBR) in work systems. } \\
\text { 2) As a result of the evaluation, } \\
\text { FBR levels of work systems are } \\
\text { determined and different studies } \\
\text { are planned for work systems } \\
\text { according to the FBR levels. } \\
\text { 3) Work system safety is } \\
\text { improved. }\end{array}$ & $\begin{array}{l}\text { fuzzy AHP } \\
\text { approach }\end{array}$ & AHP \\
\hline 36 & Analysis & $\begin{array}{l}\text { Lack of } \\
\text { strategic } \\
\text { investm } \\
\text { ent } \\
\text { decision } \\
\mathrm{s}\end{array}$ & $\begin{array}{l}\text { Khalid Hafeez } \\
\text { et al. } \\
2002\end{array}$ & $\begin{array}{l}\text { 1) The analysis may be viewed as } \\
\text { a benchmarking exercise in order } \\
\text { to find the competency gaps } \\
\text { within the company. } \\
\text { 2) The framework is generic in }\end{array}$ & $\begin{array}{l}\text { Structured } \\
\text { framework }\end{array}$ & AHP \\
\hline
\end{tabular}




\begin{tabular}{|c|c|c|c|c|c|c|}
\hline & & & & $\begin{array}{l}\text { nature and is applicable to } \\
\text { benchmark a public or service } \\
\text { sector organization. }\end{array}$ & & \\
\hline 37 & Review & $\begin{array}{l}\text { Lack of } \\
\text { challeng } \\
\text { es }\end{array}$ & $\begin{array}{l}\text { Faridun } \\
\text { Ahmadi } \\
\text { Jaafar } \\
\text { Mahmoudi } \\
2011\end{array}$ & $\begin{array}{l}\text { 1) Presented the research results } \\
\text { for determining ERP success } \\
\text { factors in Iranian } \\
\text { organizations. } \\
\text { 2) Analyzed and defined Critical } \\
\text { Success Factors (CSF) to } \\
\text { implement } \\
\text { successful ERP system in large } \\
\text { governmental organizations. }\end{array}$ & $\begin{array}{l}\text { Finding out } \\
\text { the } \\
\text { SFs(Success } \\
\text { Factors) } \\
\text { \&analyze } \\
\text { them. }\end{array}$ & $\begin{array}{l}\text { ERP } \\
\text { System }\end{array}$ \\
\hline 38 & Materials & $\begin{array}{l}\text { Lack of } \\
\text { assessm } \\
\text { ent }\end{array}$ & $\begin{array}{l}\text { ZHANG Tian- } \\
\text { yun1 et al. } \\
2007\end{array}$ & $\begin{array}{l}\text { 1) Reasonable and accurate. } \\
\text { 2) Effective method to determine } \\
\text { the weighing values for } \\
\text { assessment index of engineering } \\
\text { materials. }\end{array}$ & $\begin{array}{l}\text { Analytic } \\
\text { hierarchy } \\
\text { procedure/M } \\
\text { odel }\end{array}$ & AHP \\
\hline 39 & $\begin{array}{l}\text { Evaluati } \\
\text { on }\end{array}$ & $\begin{array}{l}\text { Lack of } \\
\text { decision }\end{array}$ & $\begin{array}{l}\text { Pooria } \\
\text { Assadi } \\
\text { Taraneh } \\
\text { Sowlati } \\
2009\end{array}$ & $\begin{array}{l}\text { 1) An aggregated decision was } \\
\text { derived considering the relative } \\
\text { influence of decision makers in } \\
\text { the decision-making process. 2) } \\
\text { Sensitivity analysis was performed } \\
\text { to evaluate the impact of changes } \\
\text { in the influence of decision } \\
\text { makers and changes in the } \\
\text { importance of selection criteria on } \\
\text { the final decision. }\end{array}$ & $\begin{array}{l}\text { The } \\
\text { recommende } \\
\text { d software } \\
\text { package was } \\
\text { acquired by } \\
\text { the company } \\
\text { and has been } \\
\text { integrated } \\
\text { into their } \\
\text { system. }\end{array}$ & AHP \\
\hline 40 & $\begin{array}{l}\text { Technolo } \\
\text { gy }\end{array}$ & $\begin{array}{l}\text { Lack of } \\
\text { strategy }\end{array}$ & $\begin{array}{l}\text { Seong Kon } \\
\text { Lee et al. } \\
2009\end{array}$ & $\begin{array}{l}\text { 1) To prioritize the weights of } \\
\text { energy technologies.2) Building } \\
\text { technology is the most preferred } \\
\text { technology in the sector of energy } \\
\text { technologies against high oil } \\
\text { prices. 3) coal technology and } \\
\text { transportation technology follows } \\
\text { and take the 2nd and 3rd place } \\
\text { with the fuzzy AHP approach }\end{array}$ & $\begin{array}{l}\text { Fuzzy } \\
\text { technique/ } \\
\text { MCDM } \\
\text { Approach }\end{array}$ & AHP \\
\hline 41 & Process & $\begin{array}{l}\text { Lack of } \\
\text { technica } \\
1 \text { people }\end{array}$ & $\begin{array}{l}\text { R. Gibney, } \\
\text { J. Shang } \\
2007\end{array}$ & $\begin{array}{l}\text { 1) The results suggest that root } \\
\text { cause of the differences was a } \\
\text { variation in emphasis on certain } \\
\text { criteria. } \\
\text { 2) Discrepancies were analyzed } \\
\text { and explained. } \\
\text { 3) The AHP provides a } \\
\text { convenient and effective tool for } \\
\text { evaluating personnel. }\end{array}$ & $\begin{array}{l}\text { Implementin } \\
\mathrm{g} \quad \text { AHP } \\
\text { Model }\end{array}$ & AHP \\
\hline 42 & Analysis & Lack of & $\frac{\text { Riddhi Dutta }}{2003}$ & $\begin{array}{l}\text { 1) These decisions can be risky. } \\
\text { 2) Estimation provides a value } \\
\text { that is as close as possible to the } \\
\text { actual (unknown) value. 3) In } \\
\text { complex situations, structured } \\
\text { approaches of decision analysis } \\
\text { become crucial for businesses. }\end{array}$ & MCDM & $\begin{array}{l}\text { Decisi } \\
\text { on } \\
\text { Analys } \\
\text { is }\end{array}$ \\
\hline 43 & Example & $\begin{array}{l}\text { Lack of } \\
\text { criterion }\end{array}$ & $\begin{array}{l}\text { R. Whitaker } \\
2007\end{array}$ & $\begin{array}{l}\text { 1) There are numerous validation } \\
\text { examples developed by many } \\
\text { people using pairwise comparison } \\
\text { matrices,hierarchies and networks } \\
\text { for which the answers are already }\end{array}$ & $\begin{array}{lr}\text { Data } & \text { from } \\
\text { ahp } & \text { and } \\
\text { ANP Model }\end{array}$ & AHP \\
\hline
\end{tabular}




\begin{tabular}{|c|c|c|c|c|c|c|}
\hline & & & & $\begin{array}{l}\text { known that show the accuracy and } \\
\text { robustness of AHP/ANP } \\
\text { and these have been shown in the } \\
\text { paper on validation of the AHP by } \\
\text { this same author in this journal. }\end{array}$ & & \\
\hline 44 & Process & $\begin{array}{l}\text { Lack of } \\
\text { selection }\end{array}$ & $\begin{array}{l}\text { David Morera } \\
2008\end{array}$ & $\begin{array}{l}\text { Presented how the DESMET } \\
\text { methodology along with the AHP } \\
\text { methodology can be combined in } \\
\text { such a way that COTS selection } \\
\text { would be easier and more accurate } \\
\text { than before. } \\
\text { COTS(Commercially Off-The } \\
\text { Shelf) evaluation is always } \\
\text { context dependent. It means that, } \\
\text { an evaluation process must be } \\
\text { carried out for a specific project } \\
\text { and not for several different } \\
\text { projects with } \\
\text { characteristics. }\end{array}$ & $\begin{array}{l}\text { DESMET } \\
\text { methodology }\end{array}$ & AHP \\
\hline $\begin{array}{l}45 \\
.\end{array}$ & $\begin{array}{l}\text { Method/ } \\
\text { procedur } \\
\text { e. }\end{array}$ & $\begin{array}{l}\text { Lack of } \\
\text { consens } \\
\text { us. }\end{array}$ & $\begin{array}{l}\text { Yucheng Dong } \\
\text { et al. } \\
2010\end{array}$ & $\begin{array}{l}\text { The geometric consistency index } \\
\text { is suggested to measure the } \\
\text { individual consistency of } \\
\text { judgement matrices. } \\
\text { Simulation experiments show that } \\
\text { the proposed two consensus } \\
\text { models can improve the consensus } \\
\text { indexes of judgement matrices to } \\
\text { help AHP decision makers reach } \\
\text { consensus. }\end{array}$ & $\begin{array}{l}\text { row } \\
\text { geometric } \\
\text { mean } \\
\text { prioritization } \\
\text { method } \\
\text { (RGMM) / } \\
\text { Simulation } \\
\text { Experiment(s } \\
\text { ). }\end{array}$ & AHP \\
\hline $\begin{array}{l}46 \\
.\end{array}$ & Analysis & $\begin{array}{l}\text { Lack of } \\
\text { appropri } \\
\text { ate } \\
\text { levels of } \\
\text { safety } \\
\text { stock }\end{array}$ & $\begin{array}{l}\text { Golam Kabir1 } \\
\text { and Dr. M. } \\
\text { Ahsan Akhtar } \\
\text { Hasin } \\
2011\end{array}$ & $\begin{array}{l}\text { In this paper, a comparative } \\
\text { analysis of AHP and FAHP for } \\
\text { multi-criteria inventory } \\
\text { classification model has been } \\
\text { presented. } \\
\text { The FAHP approach proved to be } \\
\text { a convenient method in tackling } \\
\text { practical multi-criteria decision } \\
\text { making problems. } \\
\text { It demonstrated the advantage of } \\
\text { being able to capture the } \\
\text { vagueness of human thinking and } \\
\text { to aid in solving the research } \\
\text { problem through a structured } \\
\text { manner and a simple process. }\end{array}$ & $\begin{array}{l}\text { Fuzzy } \\
\text { Analytical } \\
\text { Hierarchy } \\
\text { Process } \\
(\text { FAHP })\end{array}$ & AHP \\
\hline 47 & Analysis & $\begin{array}{l}\text { Lack of } \\
\text { fuzzy } \\
\text { MDS } \\
\text { results. }\end{array}$ & $\begin{array}{l}\text { Mei-Fang } \\
\text { Chen et al. } \\
\text { 2008M.-F. } \\
\text { CHM.-F. } \\
\text { ENG }\end{array}$ & $\begin{array}{l}\text { This paper uses fuzzy analytic } \\
\text { hierarchy process (FAHP) to } \\
\text { determine the weighting of } \\
\text { subjective judgments and to derive } \\
\text { the performance values of each } \\
\text { alternative. } \\
\text { MDS analysis is conducted to } \\
\text { identify similar groups from } \\
\text { distances among alternatives } \\
\text { based on fuzzy preferences as } \\
\text { perceived by the evaluators to } \\
\text { obtain a clear visual dimensional } \\
\text { map of a multi-criteria decision- }\end{array}$ & $\begin{array}{l}\text { fuzzy multi- } \\
\text { criteria } \\
\text { decision- } \\
\text { making } \\
\text { (FMCDM) } \\
\text { environment } \\
\text { \&Multidimen } \\
\text { sional scaling } \\
\text { (MDS) } \\
\text { analysis. }\end{array}$ & FAHP \\
\hline
\end{tabular}


Barriers of ERP while implementing ERP : A Literature Review

\begin{tabular}{|c|c|c|c|c|c|c|}
\hline & & & & making problem. & & \\
\hline 48 & $\begin{array}{l}\text { Method } \\
\text { / Analysis. }\end{array}$ & $\begin{array}{l}\text { Lack of } \\
\text { natural } \\
\text { resource } \\
\text { mgmt. } \\
\text { situation } \\
\text { s. }\end{array}$ & $\begin{array}{l}\text { G.A. } \\
\text { Mendoza }^{\text {a, }} \\
\text { H. Martins } \\
2006\end{array}$ & $\begin{array}{l}\text { Provide a critical review of } \\
\text { MCDA methods \&new MCDA } \\
\text { paradigms applied to forest and } \\
\text { other natural resource } \\
\text { management. }\end{array}$ & $\begin{array}{l}\text { MCDA } \\
\text { Method }\end{array}$ & $\begin{array}{l}\text { AHP } \\
\text { Model }\end{array}$ \\
\hline 49 & Method & $\begin{array}{l}\text { Lack of } \\
\text { new } \\
\text { ideas }\end{array}$ & $\begin{array}{ll}\text { KEUN } & \text { TAE } \\
\text { CHO } & \\
2003 & \end{array}$ & $\begin{array}{l}\text { First attempt to look at } \\
\text { multicriteria decision } \\
\text { methods waking } \\
\text { framework. }\end{array}$ & $\begin{array}{l}\text { AHP } \\
\text { Framework }\end{array}$ & AHP \\
\hline 50 & $\begin{array}{l}\text { Configur } \\
\text { ation }\end{array}$ & $\begin{array}{l}\text { Lack of } \\
\text { decision } \\
\text { making. }\end{array}$ & $\begin{array}{l}\text { F. Golbabaie } \\
\text { et al. } \\
2012\end{array}$ & $\begin{array}{l}\text { Evaluate each alternative layout } \\
\text { with respect to each of the } \\
\text { criterion and finally prioritized all } \\
\text { the alternatives. }\end{array}$ & $\begin{array}{l}\text { AHP } \\
\text { Framework }\end{array}$ & AHP \\
\hline 51 & Priorities & $\begin{array}{l}\text { Lack of } \\
\text { criterion }\end{array}$ & $\begin{array}{l}\text { T. L. SAATY } \\
\& \\
\text { M. OZDEMIR } \\
2007\end{array}$ & $\begin{array}{l}\text { People lumped together positive } \\
\text { and negative aspects of a problem. }\end{array}$ & $\begin{array}{l}\text { AHP } \\
\text { Framework }\end{array}$ & AHP \\
\hline 52 & $\begin{array}{l}\text { Ranking } \\
\text { of } \\
\text { alternativ } \\
\text { es }\end{array}$ & $\begin{array}{l}\text { Lack of } \\
\text { consiste } \\
\text { ncy }\end{array}$ & $\begin{array}{l}\text { L.C. Leung', } \\
\text { D. Cao } \\
2000\end{array}$ & $\begin{array}{l}\text { The alternatives are ranked on the } \\
\text { basis of the global weights by } \\
\text { application of a maximum- } \\
\text { minimum set ranking method. }\end{array}$ & Fuzzy AHP & AHP \\
\hline 53 & Rank & $\begin{array}{l}\text { Lack of } \\
\text { efforts }\end{array}$ & $\begin{array}{l}\text { Hung-Yi Wu } \\
\text { et al. } 2012\end{array}$ & $\begin{array}{l}\text { Conducted evaluations, improved } \\
\text { their performances and formed } \\
\text { educational policies. }\end{array}$ & $\begin{array}{l}\text { MCDM } \\
\text { Model }\end{array}$ & $\begin{array}{l}\text { Hybrid } \\
\text { AHP }\end{array}$ \\
\hline 54 & $\begin{array}{l}\text { Judgeme } \\
\text { nt }\end{array}$ & $\begin{array}{l}\text { lack of } \\
\text { consiste } \\
\text { ncy }\end{array}$ & $\begin{array}{l}\text { J. Benítez et } \\
\text { al. } \\
2011\end{array}$ & $\begin{array}{l}\text { This algorithm follows an iterative } \\
\text { feedback process that achieves an } \\
\text { acceptable level of consistency } \\
\text { while complying to some degree } \\
\text { with expert preferences. } \\
\text { Finally, an application of the } \\
\text { framework to a water management } \\
\text { decision-making problem is } \\
\text { presented. }\end{array}$ & $\begin{array}{l}\text { DSS } \\
\text { Algorithm }\end{array}$ & AHP \\
\hline 55 & $\begin{array}{l}\text { Transpor } \\
\text { tation }\end{array}$ & $\begin{array}{l}\text { Lack of } \\
\text { emergin } \\
\text { g } \\
\text { technolo } \\
\text { gy } \\
\text { usage }\end{array}$ & $\begin{array}{l}\text { T. Zayed et al. } \\
2008\end{array}$ & $\begin{array}{l}\text { The } \mathrm{R} \text { index model is developed } \\
\text { using the analytic hierarchy } \\
\text { process (AHP). } \\
\text { Results show that political risk } \\
\text { has the highest average weight of } \\
0.5196 \text {; however, financial risk } \\
\text { has the second highest average } \\
\text { weight of } 0.2336 \text { in the macro } \\
\text { level (company) areas. } \\
\text { On the other hand, in the micro } \\
\text { level (project), emerging } \\
\text { stechnology and resource risks } \\
\text { have the highest average weight of } \\
0.2492 \text { and .2098,respectively. } \\
\text { The developed R model is tested, } \\
\text { which prove its robustness in risk } \\
\text { assessment ( } 93 \% \text { ). } \\
\text { It can also be used to sort } \\
\text { highway construction projects } \\
\text { based upon risk. }\end{array}$ & $\begin{array}{l}\mathrm{R} \text { index } \\
\text { model }\end{array}$ & AHP \\
\hline 56 & $\begin{array}{l}\text { Approac } \\
\mathrm{h}\end{array}$ & $\begin{array}{l}\text { Lack of } \\
\text { compari }\end{array}$ & $\begin{array}{l}\text { CHING-FU } \\
\text { CHEN }\end{array}$ & $\begin{array}{l}\text { The findings indicate that the AHP } \\
\text { approach is a useful tool to help }\end{array}$ & $\begin{array}{l}\text { (AHP) } \\
\text { approach, a }\end{array}$ & AHP \\
\hline
\end{tabular}


Barriers of ERP while implementing ERP : A Literature Review

\begin{tabular}{|c|c|c|c|c|c|c|}
\hline & & sons. & 2006 & $\begin{array}{l}\text { support a decision in convention } \\
\text { site selection. }\end{array}$ & $\begin{array}{l}\text { decision- } \\
\text { making } \\
\text { method }\end{array}$ & \\
\hline $\begin{array}{l}57 \\
.\end{array}$ & Issues & $\begin{array}{l}\text { Lack of } \\
\text { planning }\end{array}$ & $\begin{array}{l}\text { Yang and Shi } \\
2002\end{array}$ & $\begin{array}{l}\text { The result of this study shows that } \\
\text { such an AHP application can } \\
\text { assist managers to effectively } \\
\text { evaluate firm's overall } \\
\text { performance in their long-term } \\
\text { strategic planning process even } \\
\text { under complex economic and } \\
\text { marketing conditions. }\end{array}$ & Fuzzy AHP & AHP \\
\hline $\begin{array}{l}58 \\
.\end{array}$ & Policy & $\begin{array}{l}\text { Lack of } \\
\text { policy }\end{array}$ & $\begin{array}{l}\text { Chun-hsu Lin } \\
2010\end{array}$ & $\begin{array}{l}\text { The project was found to serve as } \\
\text { a flexible and achievable } \\
\text { application of AHP to the } \\
\text { environmental policy-making } \\
\text { process. }\end{array}$ & $\begin{array}{l}\text { Decision- } \\
\text { making tools }\end{array}$ & AHP \\
\hline 59 & Analyze & $\begin{array}{l}\text { Lack of } \\
\text { certain } \\
\text { risk } \\
\text { factors. }\end{array}$ & $\begin{array}{l}\text { Prasanta } \\
\text { Kumar Dey } \\
2012\end{array}$ & $\begin{array}{l}\text { The severity of failure is } \\
\text { determined through consequence } \\
\text { analysis. } \\
\text { From this, the effect of a failure } \\
\text { caused by each risk factor can be } \\
\text { established in terms of cost, and } \\
\text { the cumulative effect of failure is } \\
\text { determined through probability } \\
\text { analysis. } \\
\text { The technique does not totally } \\
\text { eliminate subjectivity, but it is an } \\
\text { improvement over the existing } \\
\text { inspection method. }\end{array}$ & $\begin{array}{l}\text { a multiple- } \\
\text { attribute } \\
\text { decisionmaki } \\
\text { ng } \\
\text { technique, }\end{array}$ & AHP \\
\hline 60 & Analysis & $\begin{array}{l}\text { Lack of } \\
\text { correctn } \\
\text { ess/ } \\
\text { order. }\end{array}$ & $\begin{array}{l}\text { Diederik J.D. } \\
\text { Wijnmalen } \\
2007\end{array}$ & $\begin{array}{l}\text { In this paper benefits- } \\
\text { opportunities-costs-risks (BOCR) } \\
\text { analysis using AHP/ANP } \\
\text { methodology was addressed. } \\
\text { The analysis in this paper suggests } \\
\text { that it is crucial to express } \\
\text { priorities on benefits, } \\
\text { opportunities, costs and } \\
\text { risks in commensurate terms. }\end{array}$ & $\begin{array}{l}\text { AHP/ANP } \\
\text { literature. }\end{array}$ & AHP \\
\hline 61 & Analysis & $\begin{array}{l}\text { Lack of } \\
\text { shortage } \\
\text { of } \\
\text { tradition } \\
\text { al } \\
\text { analytic } \\
\text { hierarch } \\
\text { y } \\
\text { process }\end{array}$ & $\begin{array}{l}\text { Gao-yang Yin } \\
\text { et al. } \\
2011\end{array}$ & $\begin{array}{l}\text { The simulation proved that the } \\
\text { threat assessment result of anti- } \\
\text { warship missiles to warship } \\
\text { obtained through the threat } \\
\text { assessment algorithm based on } \\
\text { AHP and the } \\
\text { principal components analysis was } \\
\text { objective and reasonable. }\end{array}$ & $\begin{array}{l}\text { Threat } \\
\text { Assessment } \\
\text { Algorithm }\end{array}$ & AHP \\
\hline 62 & $\begin{array}{l}\text { Numeric } \\
\text { al }\end{array}$ & $\begin{array}{l}\text { Lack of } \\
\text { feedbac } \\
k \text { effects }\end{array}$ & $\begin{array}{l}\text { Rachung Yu, } \\
\text { Gwo-Hshiung } \\
\text { Tzeng } \\
2006\end{array}$ & $\begin{array}{l}\text { It incorporates the eigenvalue } \\
\text { method, the fuzzy cognitive maps } \\
\text { (FCM), and the weighting } \\
\text { equation, to overcome the problem } \\
\text { of preferential independent and the } \\
\text { shortcomings of the ANP. In } \\
\text { addition, two numerical examples } \\
\text { are used to demonstrate the } \\
\text { proposed method. }\end{array}$ & $\begin{array}{l}\text { fuzzy } \\
\text { cognitive } \\
\text { maps \&fuzzy } \\
\text { decision } \\
\text { maps (FDM) }\end{array}$ & $\begin{array}{l}\text { (ANP/ } \\
\text { AHP) }\end{array}$ \\
\hline 63 & Software & $\begin{array}{l}\text { Lack of } \\
\text { selection }\end{array}$ & $\begin{array}{l}\text { Dr. Chi-Tai } \\
\text { Lien }\end{array}$ & $\begin{array}{l}\text { It is found that out the business } \\
\text { process reengineering (BPR) and }\end{array}$ & Enterprise & \\
\hline
\end{tabular}




\begin{tabular}{|c|c|c|c|c|c|c|}
\hline & & criteria & $\begin{array}{l}\text { Dr. Hsiao- } \\
\text { Ling Chan } \\
2006\end{array}$ & $\begin{array}{l}\text { system tuning time' is significantly } \\
\text { important of entire criteria in this } \\
\text { ERP project. } \\
\text { It is also found that } \\
\text { 'recoverability' is the most } \\
\text { important criteria among the } \\
\text { software criteria of ERP software. }\end{array}$ & $\begin{array}{l}\text { resource } \\
\text { planning } \\
(E R P) \\
\text { software }\end{array}$ & (FAHP \\
\hline 64 & $\begin{array}{l}\text { Consulta } \\
\text { ncy/ } \\
\text { Consulta } \\
\text { nt. }\end{array}$ & $\begin{array}{l}\text { Lack of } \\
\text { decision } \\
\mathrm{s} \text { in a } \\
\text { broad } \\
\text { environ } \\
\text { ment }\end{array}$ & $\begin{array}{l}\text { Ozalp Vayvay } \\
\text { et al. } \\
2012\end{array}$ & $\begin{array}{l}\text { The experiments suggested that } \\
\text { both AHP and fuzzy AHP led to } \\
\text { the same results, but neither of } \\
\text { these considered the interactions } \\
\text { within decision elements during } \\
\text { the selection process. }\end{array}$ & $\begin{array}{l}\text { MCDM } \\
\text { \&Project } \\
\text { Resource } \\
\text { Planning } \\
\text { method } \\
\text { (PRP). }\end{array}$ & $\begin{array}{l}\text { AHP } \\
\text { \&ANP }\end{array}$ \\
\hline 65 & Analysis & $\begin{array}{l}\text { Lack of } \\
\text { "defensi } \\
\text { ve" } \\
\text { factors. }\end{array}$ & $\begin{array}{l}\text { Hsin-Pin Fu et } \\
\text { al. } \\
2006\end{array}$ & $\begin{array}{l}\text { The weights of "proactive" factors } \\
\text { are found to be greater than those } \\
\text { of "defensive"factors. } \\
\text { Various factors are found to have } \\
\text { different routes of influence in } \\
\text { determining decision making in } \\
\text { different industries. } \\
\text { Risks involving the use of new } \\
\text { technology did not constitute the } \\
\text { major factor in influencing } \\
\text { decision-making }\end{array}$ & $\begin{array}{l}\text { A fuzzy } \\
\text { analytic } \\
\text { hierarchical } \\
\text { process } \\
\text { (AHP) }\end{array}$ & $\begin{array}{l}\text { Adopti } \\
\text { on of } \\
\text { electro } \\
\text { nic } \\
\text { market } \\
\text { place } \\
\text { (EM) } \\
\text { model. }\end{array}$ \\
\hline
\end{tabular}

Table 3 : ERP Components' Barriers identified through literature review :

\begin{tabular}{|c|c|c|c|c|c|c|}
\hline S.N & $\begin{array}{l}\text { Compon } \\
\text { ent/ } \\
\text { Body/Dr } \\
\text { iver. }\end{array}$ & $\begin{array}{l}\text { Barrier ( } \\
\text { s) }\end{array}$ & $\begin{array}{l}\text { Name of } \\
\text { author \& year }\end{array}$ & Key research findings & $\begin{array}{l}\text { Methodology } \\
\text { used }\end{array}$ & $\begin{array}{l}\text { Tool( } \\
\text { s) } \\
\text { used }\end{array}$ \\
\hline 1. & Issues & $\begin{array}{l}\text { Lack of } \\
\text { realizati } \\
\text { on }\end{array}$ & $\begin{array}{l}\text { N. } \\
\text { Venkateswaran } \\
\text { and } \\
\text { V. } \\
\text { Mahalakshmi2 } \\
2012\end{array}$ & $\begin{array}{l}\text { Relative scores of issue } \\
\text { importance are compared across } \\
\text { the firms, roles (client versus } \\
\text { implementation partner) and } \\
\text { organizational levels. } \\
\text { Study findings confirm the } \\
\text { importance of this finer } \\
\text { partitioning of the data and } \\
\text { distinctions identified, reflecting } \\
\text { the circumstances of ERP } \\
\text { lifecycle implementation, } \\
\text { management and support among } \\
\text { the stakeholder groups. }\end{array}$ & $\begin{array}{l}\text { ERP life } \\
\text { cycle } \\
\text { implementati } \\
\text { on }\end{array}$ & $\begin{array}{l}\text { SAP } \\
\text { finan } \\
\text { cials }\end{array}$ \\
\hline 2. & Supplier & $\begin{array}{l}\text { Lack of } \\
\text { evaluati } \\
\text { on and } \\
\text { selection }\end{array}$ & $\begin{array}{l}\text { MOU Rui , } \\
2004\end{array}$ & $\begin{array}{l}\text { System offers the interface of } \\
\text { many kinds of data bases and has } \\
\text { the characteristic of integration } \\
\text { and extension. } \\
\text { It introduces a computer decision } \\
\text { system utilizing this model. }\end{array}$ & $\begin{array}{l}\text { ERP System } \\
\text { combined } \\
\text { with SCM }\end{array}$ & $\begin{array}{l}\text { AHP } \\
\text { Algor } \\
\text { ithm }\end{array}$ \\
\hline 3. & $\begin{array}{l}\text { Informat } \\
\text { ion } \\
\text { Systems } \\
/ \\
\text { Core }\end{array}$ & $\begin{array}{l}\text { Lack of } \\
\text { transfor } \\
\text { mation } \\
\text { and } \\
\text { specific } \\
\text { cultural } \\
\text { and } \\
\text { languag }\end{array}$ & $\begin{array}{l}\text { Liping Ge, } \\
\text { Stefan Vo } \\
2008\end{array}$ & $\begin{array}{l}\text { The first finding indicates that } \\
\text { ERP systems dominate the area of } \\
\text { information systems. } \\
\text { One of the (not unexpected) } \\
\text { findings is that not only analytical } \\
\text { data concepts play an important } \\
\text { role in successful ERP } \\
\text { implementations in China but also }\end{array}$ & $\begin{array}{l}\text { ERP } \\
\text { software }\end{array}$ & $\begin{array}{l}\text { Enter } \\
\text { prise } \\
\text { resou } \\
\text { rce } \\
\text { plann } \\
\text { ing } \\
\text { (ERP } \\
\text { ) }\end{array}$ \\
\hline
\end{tabular}




\begin{tabular}{|c|c|c|c|c|c|c|}
\hline & & $\begin{array}{l}\text { e } \\
\text { barriers }\end{array}$ & & $\begin{array}{l}\text { cultural and language aspects. } \\
\text { Introducing information systems } \\
\text { and especially ERP systems is } \\
\text { closely related to organizational } \\
\text { change. }\end{array}$ & & $\begin{array}{l}\text { syste } \\
\text { ms }\end{array}$ \\
\hline 4. & $\begin{array}{l}\text { Risk } \\
\text { factors / } \\
\text { Central }\end{array}$ & $\begin{array}{l}\text { Lack of } \\
\text { ability to } \\
\text { recruit } \\
\text { and } \\
\text { retain } \\
\text { qualified } \\
\text { ERP } \\
\text { systems } \\
\text { Develop } \\
\text { ers. } \\
\text { Lack of } \\
\text { senior } \\
\text { manage } \\
\text { ment } \\
\text { support }\end{array}$ & $\begin{array}{l}\text { MARY } \\
\text { SUMNER } \\
2000\end{array}$ & $\begin{array}{l}\text { Findings included the challenge } \\
\text { of re-engineering business } \\
\text { processes to 'fit' the process } \\
\text { which the ERP software } \\
\text { supports, investment in recruiting } \\
\text { and reskilling technology } \\
\text { professionals, the challenge of } \\
\text { using external consultants and } \\
\text { integrating their application- } \\
\text { specific knowledge and technical } \\
\text { expertise with existing teams, the } \\
\text { risk of technological bottlenecks } \\
\text { through chant-server } \\
\text { implementation and the challenge } \\
\text { of recruiting and retaining } \\
\text { business analysts who combine } \\
\text { technology and business skills. }\end{array}$ & $\begin{array}{l}\text { commercial, } \\
\text { off-the-shelf } \\
\text { COTS } \\
\text { software } \\
\text { projects. }\end{array}$ & $\begin{array}{l}\text { SAP, } \\
\text { Peopl } \\
\text { eSoft } \\
\text { and } \\
\text { Oracl } \\
\text { e } \\
\text { proje } \\
\text { cts. }\end{array}$ \\
\hline 5. & $\begin{array}{l}\text { Modular } \\
\text { set of } \\
\text { systems } \\
\text { / } \\
\text { Central }\end{array}$ & $\begin{array}{l}\text { Lack of } \\
\text { extende } \\
\mathrm{d} \\
\text { enterpris } \\
\text { e } \\
\text { function } \\
\text { ality. }\end{array}$ & $\begin{array}{l}\text { H.A. } \\
\text { Akkermans et } \\
\text { al. } \\
2003\end{array}$ & $\begin{array}{l}\text { 1) Key SCM issues. } \\
\text { 2) The second main finding is } \\
\text { that the panel experts saw only a } \\
\text { modest role for ERP in improving } \\
\text { future supply chain effectiveness } \\
\text { and a clear risk of ERP actually } \\
\text { limiting progress in SCM. } \\
\text { 3) Key limitations of current ERP } \\
\text { systems . }\end{array}$ & $\begin{array}{l}\text { A Delphi } \\
\text { study } \\
\text { research } \\
\text { design. }\end{array}$ & $\begin{array}{l}\text { Curre } \\
\text { nt } \\
\text { ERP } \\
\text { syste } \\
\text { ms }\end{array}$ \\
\hline 6. & $\begin{array}{l}\text { Corporat } \\
\mathrm{e}\end{array}$ & $\begin{array}{l}\text { Lack of } \\
\text { next- } \\
\text { generati } \\
\text { on } \\
\text { enterpris } \\
\text { e } \\
\text { systems } \\
\text { (ES). }\end{array}$ & $\begin{array}{l}\text { Charles Møller } \\
2005\end{array}$ & $\begin{array}{l}\text { The paper proposes a conceptual } \\
\text { framework for extended } \\
\text { enterprise resource planning (ERP } \\
\text { II). } \\
\text { The aim of this model is to } \\
\text { compile present ES concepts into } \\
\text { a comprehensive outline of } \\
\text { ERPII, thus composing a generic } \\
\text { map and taxonomy for corporate- } \\
\text { wide enterprise systems. }\end{array}$ & Model & $\begin{array}{l}\text { Enter } \\
\text { prise- } \\
\text { wide } \\
\text { Syste } \\
\mathrm{m} \text { ES } \\
\text { ERPI } \\
\text { I } \\
\text { Fram } \\
\text { ewor } \\
\mathrm{k}\end{array}$ \\
\hline 7. & Central & $\begin{array}{l}\text { Lack of } \\
\text { research } \\
\& \\
\text { concept } \\
\text { of } \\
\text { change } \\
\text { manage } \\
\text { ment. }\end{array}$ & $\begin{array}{l}\text { Sherry Finney } \\
\text { Martin Corbett } \\
2005\end{array}$ & $\begin{array}{l}\text { The most significant finding is the } \\
\text { lack of research that has focused } \\
\text { on the identification of CSFs from } \\
\text { the perspectives of key } \\
\text { stakeholders. } \\
\text { Additionally, there appears to be } \\
\text { much variance with respect to } \\
\text { what exactly is encompassed by } \\
\text { change management. }\end{array}$ & $\begin{array}{l}\text { Content } \\
\text { analysis } \\
\text { methodology } \\
\text { and an } \\
\text { inductive } \\
\text { coding } \\
\text { technique. }\end{array}$ & $\begin{array}{l}\text { Litera } \\
\text { ture } \\
\text { revie } \\
\mathrm{w}\end{array}$ \\
\hline 8. & Central & $\begin{array}{l}\text { Lack of } \\
\text { conform } \\
\text { ity to the } \\
\text { software } \\
\text { processe } \\
\text { s }\end{array}$ & $\begin{array}{l}\text { Dr. Ali } \quad E . \\
\text { Kashef et al. } \\
2001\end{array}$ & $\begin{array}{l}\text { This paper offers an overview of } \\
\text { Enterprise Resource Planning } \\
\text { with regard to its vision, } \\
\text { components, client expectations, } \\
\text { system parameters, benefits, } \\
\text { costs, as well as major steps }\end{array}$ & ERP System & $\begin{array}{l}\text { Litera } \\
\text { ture } \\
\text { revie } \\
\mathrm{w}\end{array}$ \\
\hline
\end{tabular}




\begin{tabular}{|c|c|c|c|c|c|c|}
\hline & & & & $\begin{array}{l}\text { towards the successful } \\
\text { implementation of ERP. }\end{array}$ & & \\
\hline 9. & $\begin{array}{l}\text { Central } \\
\& \\
\text { Corporat } \\
\text { e }\end{array}$ & $\begin{array}{l}\text { Lack of } \\
\text { ordinal } \\
\text { variable } \\
\mathrm{s}\end{array}$ & $\begin{array}{l}\text { Augusto A } \\
\text { Pacheco- } \\
\text { Comer et al. } \\
2012\end{array}$ & $\begin{array}{l}\text { The paper presents the first results } \\
\text { from empirical study where it is } \\
\text { found that there is a relation } \\
\text { between size of the company and } \\
\text { the amount of investment. } \\
\text { The general results obtained from } \\
152 \text { complete surveys shows that } \\
31.6 \% \text { belongs to micro } \\
\text { companies (1to } 10 \text { employees), } \\
23.7 \% \text { to small (11 to } 50 \\
\text { employees), } 9.2 \% \text { to medium (51 } \\
\text { to } 100 \text { employees), } 15.1 \% \text { to large } \\
\text { (101 to } 250 \text { employees) and } \\
20.4 \% \text { to big companies (more } \\
\text { than } 250 \text { employees). }\end{array}$ & $\begin{array}{l}\text { Multi Agents } \\
\text { Systems } \\
\text { (MAS) } \\
\text { architecture. }\end{array}$ & $\begin{array}{l}\text { ERP } \\
\text { Syste } \\
\text { m } \\
\text { Surve } \\
\text { y }\end{array}$ \\
\hline 10. & Core & $\begin{array}{l}\text { Lack of } \\
\text { correctn } \\
\text { ess }\end{array}$ & $\begin{array}{l}\text { Chi-Tai Lien et } \\
\text { al. } \\
2005\end{array}$ & $\begin{array}{l}\text { It is found out the 'cost' is } \\
\text { significantly important of all } \\
\text { factors } \\
\text { in this ERP project. } \\
\text { It is also found 'correctness' is } \\
\text { the most important criteria among } \\
\text { the software quality factor of ERP } \\
\text { software. } \\
\text { Among the distinctive } \\
\text { performance factors, cooperative } \\
\text { inclination, teacher's training and } \\
\text { market share are the top three } \\
\text { important criteria. }\end{array}$ & $\begin{array}{l}\text { Multi-criteria } \\
\text { decision- } \\
\text { making } \\
(\text { MCDM), } \\
\text { McCall } \\
\text { software } \\
\text { quality } \\
\text { Model. }\end{array}$ & $\begin{array}{l}\text { Enter } \\
\text { prise } \\
\text { resou } \\
\text { rce } \\
\text { plann } \\
\text { ing } \\
\text { (ERP } \\
\text { ) } \\
\text { syste } \\
\text { m \& } \\
\text { fuzzy } \\
\text { analy } \\
\text { tic } \\
\text { hierar } \\
\text { chy } \\
\text { proce } \\
\text { ss } \\
\text { (FAH } \\
\text { P). }\end{array}$ \\
\hline 11. & $\begin{array}{l}\text { Corporat } \\
\mathrm{e}\end{array}$ & $\begin{array}{l}\text { Lack of } \\
\text { weights. }\end{array}$ & $\begin{array}{l}\text { Chin-Tsai Lin } \\
\text { et al. } \\
2011\end{array}$ & $\begin{array}{l}\text { ANP and TOPSIS are used to } \\
\text { calculate the weight and give } \\
\text { suppliers a ranking; LP } \\
\text { effectively allocates order } \\
\text { quantity to each vendor. } \\
\text { As to the result, four PC board } \\
\text { suppliers are given orders for } \\
1200,727,1000 \text { and } 73 \text { pieces. }\end{array}$ & ERP model & $\begin{array}{l}\text { ANP, } \\
\text { TOP } \\
\text { SIS, } \\
\& \\
\text { LP. }\end{array}$ \\
\hline 12. & Central & $\begin{array}{l}\text { Lack of } \\
\text { function } \\
\text { ality }\end{array}$ & $\begin{array}{l}\text { P. Soffer et al. } \\
2003\end{array}$ & $\begin{array}{l}\text { The generic process and detailed } \\
\text { criteria developed, can serve for } \\
\text { comprehensive ERP modeling, as } \\
\text { well as for obtaining a model of } \\
\text { other process-supportive off-the- } \\
\text { shelf systems that are of generic } \\
\text { and configurable nature. }\end{array}$ & $\begin{array}{l}\text { Object- } \\
\text { Process } \\
\text { modeling } \\
(\text { OPM }) \\
\text { Methodology }\end{array}$ & $\begin{array}{l}\text { gener } \\
\text { ic } \\
\text { ERP } \\
\text { mode } \\
\text { ling }\end{array}$ \\
\hline 13. & Central & $\begin{array}{l}\text { Lack of } \\
\text { cultural } \\
\text { barriers }\end{array}$ & $\begin{array}{l}\text { M.C. Jones et } \\
\text { al. } \\
2006\end{array}$ & $\begin{array}{l}\text { Developed a cultural } \\
\text { configuration that shows the } \\
\text { dimensions of culture that best } \\
\text { facilitate knowledge sharing in } \\
\text { ERP implementation. }\end{array}$ & $\begin{array}{l}\text { Knowledge } \\
\text { sharing }\end{array}$ & $\begin{array}{l}\text { Litera } \\
\text { ture } \\
\text { revie } \\
\text { w. }\end{array}$ \\
\hline
\end{tabular}




\begin{tabular}{|c|c|c|c|c|c|c|}
\hline & & & & $\begin{array}{l}\text { The results also indicate ways that } \\
\text { firms may overcome cultural } \\
\text { barriers to knowledge sharing. } \\
\text { Possible research questions on } \\
\text { which future research can be } \\
\text { based are also identified. }\end{array}$ & & \\
\hline 14. & Central & $\begin{array}{l}\text { Lack of } \\
\text { erp } \\
\text { architect } \\
\text { ure. }\end{array}$ & $\begin{array}{l}\text { Edward E. } \\
\text { Watson } \\
1999\end{array}$ & $\begin{array}{l}\text { This paper identifies opportunities } \\
\text { for incorporating the ERP body of } \\
\text { knowledge into an IS program. } \\
\text { This paper focuses on curriculum } \\
\text { that is enriched through the } \\
\text { hands-on experience gained by } \\
\text { students working on a real ERP } \\
\text { system. } \\
\text { The paper also discusses related } \\
\text { topics such as costs and critical } \\
\text { success factors. }\end{array}$ & $\begin{array}{l}\text { ERP Systems } \\
\text { KnowDule } \\
\text { (Knowledge } \\
\text { Module). }\end{array}$ & $\begin{array}{l}\text { SAP } \\
\mathrm{R} / 3 \\
\text { Syste } \\
\mathrm{m}\end{array}$ \\
\hline 15. & Central & $\begin{array}{l}\text { Lack of } \\
\text { strong } \\
\text { and } \\
\text { committ } \\
\text { ed } \\
\text { leadersh } \\
\text { ip. }\end{array}$ & $\begin{array}{l}\text { S. Sarker, } \\
\text { A.S. Lee, } \\
2003\end{array}$ & $\begin{array}{l}\text { In a longitudinal positivist case } \\
\text { study, it is found that, while all } \\
\text { three enablers may contribute to } \\
\text { ERP implementation success, } \\
\text { only strong and committed } \\
\text { leadership can be empirically } \\
\text { established as a necessary } \\
\text { condition. }\end{array}$ & $\begin{array}{l}\text { A critical } \\
\text { embedded } \\
\text { single-case } \\
\text { design }\end{array}$ & $\begin{array}{l}\text { ERP } \\
\text { enabl } \\
\text { ers }\end{array}$ \\
\hline 16. & Central & $\begin{array}{l}\text { Lack of } \\
\text { determin } \\
\text { ant } \\
\text { factors. }\end{array}$ & $\begin{array}{l}\text { Man-Kit } \\
\text { Chang et al. } \\
2008\end{array}$ & $\begin{array}{l}\text { Research results show that social } \\
\text { factors are the most significant } \\
\text { determinant affecting the ERP } \\
\text { system usage. } \\
\text { Other factors such as } \\
\text { compatibility and near-term } \\
\text { consequences are also significant. } \\
\text { Based on findings, it is also } \\
\text { proposed some important } \\
\text { managerial implications in } \\
\text { connection to promoting the } \\
\text { usage. }\end{array}$ & $\begin{array}{l}\text { conceptual } \\
\text { model } \\
\text { derived from } \\
\text { the Triandis } \\
\text { framework. }\end{array}$ & $\begin{array}{l}\text { ERP } \\
\text { syste } \\
\text { m. }\end{array}$ \\
\hline 17. & Central & $\begin{array}{l}\text { Lack of } \\
\text { Organiz } \\
\text { ational } \\
\text { change }\end{array}$ & $\begin{array}{l}\text { G. Buonanno } \\
\text { et al. } \\
2004\end{array}$ & $\begin{array}{l}\text { Companies seem to be } \\
\text { disregarding ERP systems as an } \\
\text { answer to their business } \\
\text { complexity. } \\
\text { SMEs disregard financial } \\
\text { constraints as the main cause for } \\
\text { ERP system } \\
\text { non-adoption, suggesting } \\
\text { structural and organizational } \\
\text { reasons as major ones. }\end{array}$ & $\begin{array}{l}\text { Questionnair } \\
\mathrm{e}\end{array}$ & $\begin{array}{l}\text { Conc } \\
\text { eptua } \\
1 \\
\text { frame } \\
\text { work. }\end{array}$ \\
\hline 18. & Central & $\begin{array}{l}\text { Lack of } \\
\text { technica } \\
1 \\
\text { knowled } \\
\text { ge }\end{array}$ & $\begin{array}{l}\text { Xin Chan et } \\
\text { al. } \\
2002\end{array}$ & $\begin{array}{l}\text { ERP solutions are an integral part } \\
\text { of the emerging Digital Economy, } \\
\text { not just as a precursor or back- } \\
\text { office component, but as a } \\
\text { foundation or trampoline for } \\
\text { multinationals to avail themselves } \\
\text { of new technologies (I.T. related } \\
\text { or others). } \\
\text { Recent studies and analysis } \\
\text { suggest other avenues to explore } \\
\text { in order to increase }\end{array}$ & $\begin{array}{l}\text { I.T. software } \\
\text { projects of } \\
\text { ERP } \\
\text { solutions. }\end{array}$ & $\begin{array}{l}\text { Digit } \\
\text { al } \\
\text { Econ } \\
\text { omy }\end{array}$ \\
\hline
\end{tabular}




\begin{tabular}{|c|c|c|c|c|c|c|}
\hline & & & & implementation success rate. & & \\
\hline 19. & $\begin{array}{l}\text { Central } \\
\text { and } \\
\text { Corporat } \\
\text { e }\end{array}$ & $\begin{array}{l}\text { Lack of } \\
\text { national } \\
\text { differen } \\
\text { ces and } \\
\text { cultural } \\
\text { issues }\end{array}$ & $\begin{array}{l}\text { C. Sheu et al. } \\
2004\end{array}$ & $\begin{array}{l}\text { The findings confirm that national } \\
\text { differences affect multinational } \\
\text { ERP implementation practices. } \\
\text { The findings suggest that } \\
\text { language, culture, politics, } \\
\text { government regulations, } \\
\text { management style, and labor } \\
\text { skills impact various ERP } \\
\text { implementation practices at } \\
\text { different countries. } \\
\text { Understanding such effects will } \\
\text { enable companies to be more } \\
\text { proactive in planning project } \\
\text { budget and duration. }\end{array}$ & $\begin{array}{l}\text { Case study } \\
\text { and } \\
\text { secondary } \\
\text { data } \\
\text { research } \\
\text { method. }\end{array}$ & $\begin{array}{l}\text { Data } \\
\text { analy } \\
\text { sis \& } \\
\text { Resea } \\
\text { rch } \\
\text { validi } \\
\text { ty } \\
\text { tests. }\end{array}$ \\
\hline 20. & Core & $\begin{array}{l}\text { Lack of } \\
\text { project } \\
\text { perspect } \\
\text { ive }\end{array}$ & $\begin{array}{l}\text { Michael } \\
\text { Rosemann, } \\
\text { Jens Wiese, } \\
1999 .\end{array}$ & $\begin{array}{l}\text { The implementation process is } \\
\text { evaluated. } \\
\text { Balanced Scorecards are typically } \\
\text { designed to monitor business } \\
\text { processes. } \\
\text { It focuses in most cases on only } \\
\text { one process -implementation. } \\
\text { As far as possible the Balanced } \\
\text { Scorecard functionality within } \\
\text { ERP software will be used to } \\
\text { realize an IT-based solution. }\end{array}$ & $\begin{array}{l}\text { BSC } \\
\text { (Balanced } \\
\text { Scorecard ) } \\
\text { approach }\end{array}$ & $\begin{array}{l}\text { ERP } \\
\text { Softw } \\
\text { are }\end{array}$ \\
\hline 21. & $\begin{array}{l}\text { Core } \\
\text { and } \\
\text { Central }\end{array}$ & $\begin{array}{l}\text { Lack of } \\
\text { particula } \\
r \text { focus } \\
\text { on } \\
\text { resource } \\
\text { s. }\end{array}$ & $\begin{array}{l}\text { Helmut Klaus } \\
\text { et al. } \\
2001\end{array}$ & $\begin{array}{l}\text { The term ERP suggest the } \\
\text { outcome of the historical } \\
\text { development process; yet this } \\
\text { process has some discontinuity, } \\
\text { and it would be erroneous to } \\
\text { assume that ERP literally means } \\
\text { enterprise-wide planning of } \\
\text { resources. } \\
\text { Thus, Thomas Davenport } \\
\text { (Davenport 2000) and Laudon } \\
\text { and Laudon (Laudon and Laudon } \\
\text { 2000) have argued strongly in } \\
\text { favour of replacing the term ERP } \\
\text { with Business Systems. This } \\
\text { would also take into account that } \\
\text { these systems are universal and } \\
\text { not limited to manufacturing } \\
\text { installations. }\end{array}$ & $\begin{array}{l}\text { Historical } \\
\text { analysis and } \\
\text { Meta } \\
\text { Analysis. }\end{array}$ & $\begin{array}{l}\text { IS } \\
\text { literat } \\
\text { ure \& } \\
\text { MIS } \\
\text { of } \\
\text { ERP }\end{array}$ \\
\hline 22. & Central & $\begin{array}{l}\text { Lack of } \\
\text { projects }\end{array}$ & $\begin{array}{l}\text { Päivi Iskanius } \\
2009\end{array}$ & $\begin{array}{l}\text { This study presents experiences } \\
\text { that are obtained in case studies in } \\
\text { which three SME companies were } \\
\text { drawn an ERP project risk } \\
\text { analysis and characteristics } \\
\text { analysis. } \\
\text { The critical risks of the ERP } \\
\text { projects have been identified and } \\
\text { assessed. } \\
\text { By using characteristics analysis } \\
\text { method, the recommendations of } \\
\text { how to divide the ERP projects } \\
\text { into manageable sub projects have }\end{array}$ & $\begin{array}{l}\text { Characteristi } \\
\text { cs analysis } \\
\text { method }\end{array}$ & $\begin{array}{l}\text { Case } \\
\text { study }\end{array}$ \\
\hline
\end{tabular}




\begin{tabular}{|c|c|c|c|c|c|c|}
\hline & & & & been given. & & \\
\hline 23. & Central & $\begin{array}{l}\text { Lack of } \\
\text { research } \\
\text { in ERP } \\
\text { area. }\end{array}$ & $\begin{array}{l}\text { Majed } \\
\text { Mashari } \\
2003\end{array}$ & $\begin{array}{l}\text { This paper has presented a survey } \\
\text { of research relating to some major } \\
\text { ERP issues. } \\
\text { The paper has illustrated a } \\
\text { taxonomy of ERP research that is } \\
\text { believed to be covering the major } \\
\text { issues in this important field. }\end{array}$ & $\begin{array}{l}\text { Literature } \\
\text { review }\end{array}$ & $\begin{array}{l}\text { ERP } \\
\text { Modu } \\
\text { les }\end{array}$ \\
\hline 24. & $\begin{array}{l}\text { Collabor } \\
\text { ative }\end{array}$ & $\begin{array}{l}\text { Lack of } \\
\text { competit } \\
\text { iveness. }\end{array}$ & $\begin{array}{l}\text { Injazz J. Chen } \\
2001\end{array}$ & $\begin{array}{l}\text { Study identifies new windows of } \\
\text { opportunities as well as } \\
\text { challenges facing companies } \\
\text { today. } \\
\text { Analyzes several critical planning } \\
\text { issues and choosing a right ERP } \\
\text { system. }\end{array}$ & $\begin{array}{l}\text { Literature } \\
\text { review }\end{array}$ & $\begin{array}{l}\text { ERP } \\
\text { Syste } \\
\mathrm{m}\end{array}$ \\
\hline 25. & Central & $\begin{array}{l}\text { Lack of } \\
\text { informat } \\
\text { ion }\end{array}$ & $\begin{array}{l}\text { S.-W. Chien, } \\
\text { S.-M. Tsaur } \\
2007\end{array}$ & $\begin{array}{l}\text { The results indicated that } \\
\text { technological newness was the } \\
\text { most important factor in } \\
\text { determining the quality of the } \\
\text { system. } \\
\text { The pursuit of state-of-the art } \\
\text { technology is a risky proposition. } \\
\text { Proposed a success model \& } \\
\text { empirically tested the } \\
\text { relationships between variables. }\end{array}$ & $\begin{array}{l}\text { Data } \\
\text { analysis }\end{array}$ & $\begin{array}{l}\text { ERP } \\
\text { Syste } \\
\mathrm{m} \\
\text { Mode } \\
1\end{array}$ \\
\hline 26. & Central & $\begin{array}{l}\text { Lack of } \\
\text { repair \& } \\
\text { mainten } \\
\text { ance. }\end{array}$ & $\begin{array}{l}\text { P. Mandal, } \\
\text { A. } \\
\text { Gunasekaran } \\
2003\end{array}$ & $\begin{array}{l}\text { In summary, as part of the new ERP imple- } \\
\text { mentation process a review of the legacy systems } \\
\text { were carried out. It was found that repair was not } \\
\text { cost effective and replacement was the only option. } \\
\text { system was tested, business rules promulgated, } \\
\text { processes documented, data converted over, staff } \\
\text { training organized and run, and it went live on time. }\end{array}$ & Case study & $\begin{array}{l}\text { SAP- } \\
\text { PS } \\
\text { Modu } \\
\text { le }\end{array}$ \\
\hline 27. & Central & $\begin{array}{l}\text { Lack of } \\
\text { SMEs. }\end{array}$ & $\begin{array}{l}\text { D.L. Olson, } \\
\text { B. Chae and } \\
\text { C. Sheu } \\
2005\end{array}$ & $\begin{array}{l}\text { Multinational ERP } \\
\text { implementations radically change } \\
\text { organizational information } \\
\text { systems. } \\
\text { Careful planning of how to } \\
\text { implement ERP systems is needed } \\
\text { in multinational environments in } \\
\text { order to identify the best ERP } \\
\text { design and the best redesign of } \\
\text { business processes. }\end{array}$ & Case study & $\begin{array}{l}\text { SCM } \\
\& \\
\text { ERP } \\
\text { Syste } \\
\text { m }\end{array}$ \\
\hline 28. & Central & $\begin{array}{l}\text { Lack of } \\
\text { risk } \\
\text { manage } \\
\text { ment in } \\
\text { ERP } \\
\text { impleme } \\
\text { ntation. }\end{array}$ & $\begin{array}{l}\text { Dr. Bernard } \\
\text { Wong, } \\
\text { David Tein } \\
2003\end{array}$ & $\begin{array}{l}\text { The findings include a list of } 23 \\
\text { unique Critical Success Factors } \\
\text { identified throughout the } \\
\text { literature, which we believe to be } \\
\text { essential for Project Managers. } \\
\text { Identifying the CSFs of an ERP } \\
\text { implementation is paramount to } \\
\text { ensure the success of the project. }\end{array}$ & $\begin{array}{l}\text { Literature } \\
\text { survey }\end{array}$ & $\begin{array}{l}\text { ERP } \\
\text { Proje } \\
\text { ct }\end{array}$ \\
\hline
\end{tabular}




\begin{tabular}{|c|c|c|c|c|c|c|}
\hline 29. & Central & $\begin{array}{l}\text { Lack of } \\
\text { distincti } \\
\text { on }\end{array}$ & $\begin{array}{l}\text { Lars Brehm et } \\
\text { al. } \\
2000\end{array}$ & $\begin{array}{l}\text { ERP packages do not fit cleanly } \\
\text { into the custom/off-the shelf } \\
\text { distinction. } \\
\text { Describes a portfolio of tailoring } \\
\text { options between configuration } \\
\text { and modification, with important } \\
\text { implications for implementation } \\
\text { risk and the difficulty of ERP } \\
\text { system upgrades. }\end{array}$ & IS literature & $\begin{array}{l}\text { ERP } \\
\text { softw } \\
\text { are }\end{array}$ \\
\hline 30. & Central & $\begin{array}{l}\text { Lack of } \\
\text { organiza } \\
\text { tional } \\
\text { culture } \\
\text { impact }\end{array}$ & $\begin{array}{l}\text { Z. Zhang et al. } \\
2005\end{array}$ & $\begin{array}{l}\text { This study develops an ERP } \\
\text { implementation success } \\
\text { framework by adapting the Ives et } \\
\text { al. information systems (ISs) } \\
\text { research model and DeLone and } \\
\text { McLean's IS success model to } \\
\text { identify both critical success } \\
\text { factors and success measures. } \\
\text { Atlas/ti program is used to } \\
\text { facilitate data analysis. }\end{array}$ & $\begin{array}{l}\text { Literature } \\
\text { review / } \\
\text { Qualitative } \\
\text { case study } \\
\text { research } \\
\text { methodology }\end{array}$ & $\begin{array}{l}\text { DeLo } \\
\text { ne } \\
\text { and } \\
\text { McLe } \\
\text { an's } \\
\text { IS } \\
\text { succe } \\
\text { ss } \\
\text { mode } \\
1\end{array}$ \\
\hline 31. & Central & $\begin{array}{l}\text { Lack of } \\
\text { misses } \\
\text { /hits \& } \\
\text { errors. }\end{array}$ & $\begin{array}{l}\text { Maarten A.S. } \\
\text { Boksem et al. } \\
2006\end{array}$ & $\begin{array}{l}\text { No correlations were found } \\
\text { between BIS and Pe amplitude or } \\
\text { between BAS and ERN/Ne } \\
\text { amplitude. } \\
\text { Results are discussed in terms of } \\
\text { individual differences in reward } \\
\text { and punishment sensitivity that } \\
\text { are reflected in error related ERP } \\
\text { components. }\end{array}$ & $\begin{array}{l}\text { Behavioral } \\
\text { Activation } \\
\text { System/ } \\
\text { Behavioral } \\
\text { Inhibition } \\
\text { System } \\
\text { (BIS/BAS) } \\
\text { scales. }\end{array}$ & $\begin{array}{l}\text { error } \\
\text { relate } \\
\text { d } \\
\text { negat } \\
\text { ively } \\
\text { (ERN } \\
/ \mathrm{Ne} \text { ) } \\
\text { factor } \\
\text { s. } \\
\text { ERP } \\
\text { analy } \\
\text { ses \& } \\
\text { Data } \\
\text { Anal } \\
\text { ysis. }\end{array}$ \\
\hline 32. & Central & $\begin{array}{l}\text { Lack of } \\
\text { study } \\
\text { research }\end{array}$ & $\begin{array}{l}\text { Mohamad } \\
\text { Mohsen. } \\
\text { Sedighi et al. } \\
2012\end{array}$ & $\begin{array}{l}\text { This study tries to define a proper } \\
\text { conceptual model for ERP- } \\
\text { implementation in agile } \\
\text { organizations. } \\
\text { It is also endeavored to propose a } \\
\text { method for prioritizing these } \\
\text { phases and effectively assess } \\
\text { agility during ERP lifecycle. }\end{array}$ & $\begin{array}{l}\text { ERP } \\
\text { lifecycle } \\
\text { phases }\end{array}$ & $\begin{array}{l}\text { Conc } \\
\text { eptua } \\
1 \\
\text { mode } \\
1\end{array}$ \\
\hline 33. & Central & $\begin{array}{l}\text { Lack of } \\
\text { multidi } \\
\text { mension } \\
\text { al } \\
\text { variable }\end{array}$ & $\begin{array}{ll}\text { Guy } & \text { Janssens } \\
\text { et al. } & \\
2008 & \end{array}$ & $\begin{array}{l}\text { Logical clusters of ERP project } \\
\text { activities can be used in further } \\
\text { research to find variables for } \\
\text { defining the size of an ERP } \\
\text { implementation project. }\end{array}$ & $\begin{array}{l}\text { Literature } \\
\text { survey }\end{array}$ & $\begin{array}{l}\text { ERP } \\
\text { proje } \\
\text { cts }\end{array}$ \\
\hline 34. & Central & $\begin{array}{l}\text { Lack of } \\
\text { training. }\end{array}$ & $\begin{array}{l}\text { Valerie Botta- } \\
\text { Genoulaz et al. } \\
2005\end{array}$ & $\begin{array}{l}\text { A classification of company } \\
\text { positions regarding their ERP use, } \\
\text { based on both software maturity } \\
\text { and strategic deployment } \\
\text { directions, and an improvement } \\
\text { process are proposed. } \\
\text { Total } 3 \text { surveys and } 5 \text { stages have } \\
\text { been found out while } \\
\text { implementation of ERP. }\end{array}$ & $\begin{array}{l}\text { The survey } \\
\text { questionnaire }\end{array}$ & $\begin{array}{l}\text { ERP } \\
\text { Syste } \\
\text { ms \& } \\
\text { proje } \\
\text { cts. }\end{array}$ \\
\hline
\end{tabular}




\begin{tabular}{|c|c|c|c|c|c|c|}
\hline 35. & Central & $\begin{array}{l}\text { Lack of } \\
\text { selection } \\
\text { criteria. }\end{array}$ & $\begin{array}{l}\text { Wen-Hsien } \\
\text { Tsai et al. } \\
2012\end{array}$ & $\begin{array}{l}\text { Developed a conceptual } \\
\text { framework for investigating how } \\
\text { ERP selection criteria are linked } \\
\text { to system quality and the service } \\
\text { provided by suppliers and } \\
\text { consultants, and thus how these } \\
\text { influenced ERP implementation } \\
\text { success. } \\
\text { Study also suggested that } \\
\text { enhanced system quality and } \\
\text { service quality could increase user } \\
\text { perspective and ERP success. }\end{array}$ & $\begin{array}{l}\text { Cross- } \\
\text { sectional } \\
\text { survey }\end{array}$ & $\begin{array}{l}\text { Conc } \\
\text { eptua } \\
1 \\
\text { frame } \\
\text { work }\end{array}$ \\
\hline 36. & Central & $\begin{array}{l}\text { Lack of } \\
\text { ES } \\
\text { impleme } \\
\text { ntation }\end{array}$ & $\begin{array}{l}\text { J. Ward et al. } \\
2005\end{array}$ & $\begin{array}{l}\text { The findings from the case studies } \\
\text { suggest that the framework can } \\
\text { help understand how different } \\
\text { approaches to managing ES } \\
\text { implementations both address and } \\
\text { influence the behaviors of key } \\
\text { interest groups and hence the } \\
\text { achievement of the benefits } \\
\text { expected from the investment. }\end{array}$ & Case studies & $\begin{array}{l}\text { Fram } \\
\text { ewor } \\
\mathrm{k} \\
\text { (ERP } \\
\text { ) }\end{array}$ \\
\hline 37. & $\begin{array}{l}\text { Collabor } \\
\text { ative }\end{array}$ & $\begin{array}{l}\text { Lack of } \\
\text { engg. } \\
\text { Integrati } \\
\text { on \& } \\
\text { approac } \\
\text { h. }\end{array}$ & $\begin{array}{l}\text { Boonserm K. } \\
\text { et al. } \\
2000\end{array}$ & $\begin{array}{l}\text { This paper illustrates the } \\
\text { requirements of information } \\
\text { models. } \\
\text { Presents an integration approach. }\end{array}$ & $\begin{array}{l}\text { Functional } \\
\text { approach }\end{array}$ & $\begin{array}{l}\text { ERP } \\
\text { Integr } \\
\text { ation }\end{array}$ \\
\hline 38. & $\begin{array}{l}\text { Collabor } \\
\text { ative }\end{array}$ & $\begin{array}{l}\text { Lack of } \\
\text { MDBM } \\
\text { concept }\end{array}$ & $\begin{array}{l}\text { J.A. Gulla, } \\
\text { T. Brasethvik } \\
2002\end{array}$ & $\begin{array}{l}\text { Dynamic and adaptable business } \\
\text { models constructed as part of the } \\
\text { implementation project. } \\
\text { Discussed how the linguistic part } \\
\text { and the modeling part of MDBM } \\
\text { mutually support each other. }\end{array}$ & $\begin{array}{l}\text { model-driven } \\
\text { business } \\
\text { management } \\
\text { (MDBM) } \\
\text { approach }\end{array}$ & $\begin{array}{l}\text { SAP } \\
\text { R/3 }\end{array}$ \\
\hline 39. & Central & $\begin{array}{l}\text { Lack of } \\
\text { efficient } \\
\text { mainten } \\
\text { ance }\end{array}$ & $\begin{array}{l}\text { O.B. Kwon et } \\
\text { al. } \\
2001\end{array}$ & $\begin{array}{l}\text { Proto type agent system is } \\
\text { proposed. } \\
\text { How the changes will affect an } \\
\text { ERP performance. }\end{array}$ & $\begin{array}{l}\text { Multi agent } \\
\text { intelligent } \\
\text { technology }\end{array}$ & $\begin{array}{l}\text { ERP/ } \\
\text { PN } \\
\text { Datab } \\
\text { ase }\end{array}$ \\
\hline 40. & Central & $\begin{array}{l}\text { Lack of } \\
\text { mainten } \\
\text { ance }\end{array}$ & $\begin{array}{l}\text { J.L. Salmeron, } \\
\text { C. Lopez } \\
2010\end{array}$ & $\begin{array}{l}\text { The maintenance of the ERP is } \\
\text { necessary to correct and prevent } \\
\text { systems failures as well as to } \\
\text { enhance its performance and } \\
\text { adapt continuously to the system. } \\
\text { Risk factors identified and } \\
\text { analyzed. } \\
\text { The most important hazards in } \\
\text { ERP maintenance are the } \\
\text { cooperation and commitment of } \\
\text { ERP users and managers. }\end{array}$ & $\begin{array}{l}\text { analytic } \\
\text { hierarchy } \\
\text { process } \\
\text { (AHP) } \\
\text { methodology }\end{array}$ & $\begin{array}{l}\text { (ERP } \\
\text { ) } \\
\text { syste } \\
\text { ms }\end{array}$ \\
\hline
\end{tabular}


Table 4:

An Extended Literature : The reduced construct and barrier item of an ERP Construct:-

\begin{tabular}{lll}
\hline Construct & Barrier(ERP) & \multicolumn{2}{c}{ Literature } \\
Process & Lack of perfection , lack of software & Ike C. Ehie et al.(2005) \\
,.Jacques Verville et al. & acquisition process \& complexities and & (2003)and Claire Berchet et \\
al.(2005). & &
\end{tabular}

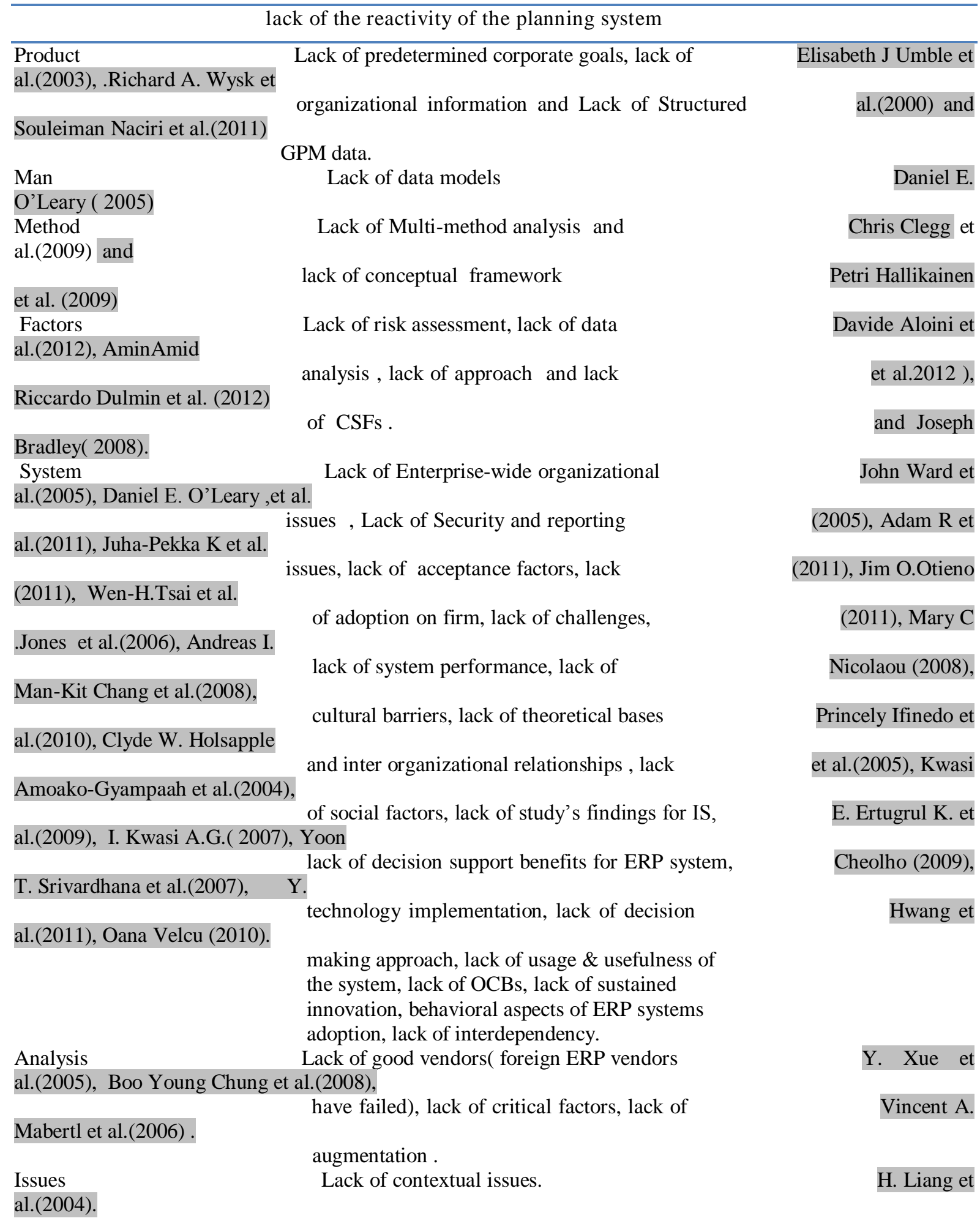


O’Leary (2004), V. Chapurlat et al.(2008),

Enterprise/ Firm activities, lack of firm competences.

al.(2010), Eric T.G. Wang et al. (2006).

Lack of group cohesion

\begin{tabular}{|c|c|}
\hline \multicolumn{2}{|c|}{ Table 5: Contributions - ERP Barriers } \\
\hline Contributions & Author(s) with year \\
\hline $\begin{array}{l}\text { Coping with ERP-related contextual issues in SMEs: a } \\
\text { vendor's perspective. }\end{array}$ & H. Liang, Y. Xue et al., 2004 \\
\hline $\begin{array}{l}\text { Aligning ERP implementation with competitive priorities of } \\
\text { manufacturing firms: An exploratory study. }\end{array}$ & H.R. Yen, C. Sheu, 2004 \\
\hline Enterprise systems, knowledge transfer and power users. & O. Volkoff et al.,2004 \\
\hline $\begin{array}{l}\text { An extension of the technology acceptance model in an ERP } \\
\text { implementation environment. }\end{array}$ & K. Amoako-Gyampah, A.F. Salam, 2004 \\
\hline $\begin{array}{l}\text { 'Best' for whom? : the tension between 'best practice' ERP } \\
\text { packages and diverse epistemic cultures in a university } \\
\text { context. }\end{array}$ & E.L. Wagner, S. Newell, 2004 \\
\hline $\begin{array}{l}\text { Aligning an ERP system with enterprise requirements : An } \\
\text { object-process based approach. }\end{array}$ & P. Soffer et al., 2005 \\
\hline $\begin{array}{l}\text { Going beyond 'misfit' as a reason for ERP package } \\
\text { customization. }\end{array}$ & B. Light, 2005 \\
\hline $\begin{array}{l}\text { Exploring knowledge sharing in ERP implementation: an } \\
\text { organizational culture framework. }\end{array}$ & M.C. Jones et al., 2006 \\
\hline $\begin{array}{l}\text { Information technology and systems justifications : A review } \\
\text { for research and applications. }\end{array}$ & A. Gunasekaran et al., 2006 \\
\hline $\begin{array}{l}\text { Effects of internal support and consultant quality on the } \\
\text { consulting process and ERP system quality. }\end{array}$ & E.T.G. Wang, J.H.F. Chen, 2006 \\
\hline $\begin{array}{l}\text { The impact of enterprise systems on corporate performance: } \\
\text { A study of ERP, SCM, and CRM system implementations. } \\
\text { ERP systems as an enabler of sustained business process } \\
\text { innovation : A knowledge- based view. }\end{array}$ & T. Srivardhana, S.D. Pawlowski, 2007 \\
\hline $\begin{array}{l}\text { The role of readiness for change in ERP implementation: } \\
\text { Theoretical bases and empirical validation. }\end{array}$ & K.-Y. Kwahk, J.-N. Lee, 2008 \\
\hline $\begin{array}{l}\text { ERPII : The involvement, benefits and impediments of } \\
\text { collaborative information sharing. }\end{array}$ & S.C.L. Koh et al., 2008 \\
\hline $\begin{array}{l}\text { A practical model on controlling the ERP implementation } \\
\text { risks. }\end{array}$ & A. Hakim, H. Hakim, 2010 \\
\hline $\begin{array}{l}\text { An empirical investigation of the impacts of internal/external } \\
\text { facilitators on the project success of ERP : A structural } \\
\text { equation model. }\end{array}$ & W.-H. Tsai et al., 2011 \\
\hline $\begin{array}{l}\text { Drivers, barriers, and critical success factors for ERPII } \\
\text { implementation in supply chains : A critical analysis. }\end{array}$ & S.C.L. Koh et al., 2011 \\
\hline $\begin{array}{l}\text { Analysis of information integration benefit drivers and } \\
\text { implementation hindrances. }\end{array}$ & Y. Kang et al., 2012 \\
\hline $\begin{array}{l}\text { Coding-error based defects in enterprise resource planning } \\
\text { software: Prevention, discovery, elimination and mitigation. }\end{array}$ & I. Woungang et al., 2012 \\
\hline $\begin{array}{l}\text { Identification and classification of ERP critical failure } \\
\text { factors in Iranian industries. }\end{array}$ & A. Amid et al., 2012 \\
\hline $\begin{array}{l}\text { Relationship bonding for a better knowledge transfer climate } \\
\text { : An ERP implementation research. }\end{array}$ & W.-H. Hung et al., 2012 \\
\hline
\end{tabular}


Table 6 : Details of Literature Review for above Table 5 :

\begin{tabular}{|c|c|c|c|}
\hline Technique(s) & Proponent(s) & Methodology & Application(s) \\
\hline $\begin{array}{l}\text { Dialectic and cultural } \\
\text { perspective }\end{array}$ & H. Liang, Y. Xue et al. & $\begin{array}{l}\text { Case research method, } \\
\text { UF Soft method. }\end{array}$ & 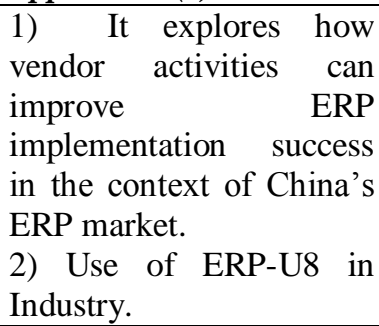 \\
\hline $\begin{array}{lr}\text { Direct } & \text { observation } \\
\text { and } & \text { systematic } \\
\text { interviews } & \end{array}$ & H.R. Yen, C. Sheu . & Case research method & $\begin{array}{l}\text { 1) Used in data } \\
\text { integration. } \\
\text { 2) Application in ERP } \\
\text { implementation cases. }\end{array}$ \\
\hline $\begin{array}{lr}\text { KT } & \text { (Knowledge } \\
\text { Transfer) } & \text { ES- } \\
\text { Enterprise } & \text { System } \\
\text { KT } & \end{array}$ & O. Volkoff et al. & $\begin{array}{ll}\text { Multiple } & \text { case study } \\
\text { approach } & \& \text { cross-case } \\
\text { analysis } & \end{array}$ & $\begin{array}{l}\text { 1) Power users -super } \\
\text { users (employees). } \\
\text { 2) Training and } \\
\text { personnel transfer. } \\
\text { 3) Helps (applied) in } \\
\text { overcoming barriers. }\end{array}$ \\
\hline $\begin{array}{l}\text { Meta analysis of } \\
\text { TAM(Technology } \\
\text { Acceptance Model) } \\
\text { research. }\end{array}$ & $\begin{array}{l}\text { K. Amoako-Gyampah, } \\
\text { A.F. Salam }\end{array}$ & $\begin{array}{l}\text { Empirical and theoretical } \\
\text { support. }\end{array}$ & $\begin{array}{l}\text { 1) Both training and } \\
\text { project communication } \\
\text { influence the shared } \\
\text { beliefs. } \\
\text { 2) Shared beliefs } \\
\text { influence the perceived } \\
\text { usefulness and ease of use } \\
\text { of the technology. }\end{array}$ \\
\hline Epistemic cultures & E.L. Wagner, S. Newell & $\begin{array}{l}\text { Interpretive research; } \\
\text { Longitudinal research. }\end{array}$ & $\begin{array}{l}\text { ERP development } \\
\text { alliance between Ivy and } \\
\text { Vision resulted in a 'best } \\
\text { practice' product which is } \\
\text { being marketed on the } \\
\text { vendor's international } \\
\text { web site as their 'higher } \\
\text { education industry } \\
\text { solution' appropriate for } \\
\text { universities across } \\
\text { cultural and geographical } \\
\text { contexts. }\end{array}$ \\
\hline $\begin{array}{ll}\text { An } & \text { iterative } \\
\text { alignment } & \text { process- } \\
\text { Algorithm. } & \end{array}$ & P. Soffer et al. & $\begin{array}{l}\text { Object-Process } \\
\text { Methodology (OPM) }\end{array}$ & $\begin{array}{l}\text { 1) The alignment } \\
\text { algorithm has been tested } \\
\text { in an experimental study. } \\
\text { 2) Results demonstrate } \\
\text { the ability of the approach } \\
\text { to provide a satisfactory } \\
\text { solution to the problem of } \\
\text { aligning an ERP software } \\
\text { package with an } \\
\text { enterprise business } \\
\text { model. }\end{array}$ \\
\hline Customization & B. Light & $\begin{array}{l}\text { Case } \\
\text { studies of the } \\
\text { customization of ERP } \\
\text { packages. }\end{array}$ & $\begin{array}{l}\text { 1) Facilitate a smoother } \\
\text { implementation. } \\
\text { 2) Reduces the number of } \\
\text { staff in that area - thus } \\
\text { reducing costs. } \\
\text { 3) Adds value to the ERP } \\
\text { package. }\end{array}$ \\
\hline Conceptual research & M.C. Jones et al. & Multisite case study & 1) It indicates ways that \\
\hline
\end{tabular}




\begin{tabular}{|c|c|c|c|}
\hline model & & & $\begin{array}{l}\text { firms may overcome } \\
\text { cultural barriers to } \\
\text { knowledge sharing. } \\
\text { 2) A model is developed. }\end{array}$ \\
\hline $\begin{array}{l}\text { Analytic approaches } \\
\text { and the associated } \\
\text { tools and techniques. }\end{array}$ & A. Gunasekaran et al. & A literature review & $\begin{array}{l}\text { 1) Assemble meaningful } \\
\text { information for the } \\
\text { development of a } \\
\text { framework for IT/IS } \\
\text { evaluation. } \\
\text { 2) Better reflects the new } \\
\text { business environment. }\end{array}$ \\
\hline $\begin{array}{l}\text { Conceptual } \\
\text { background } \\
\text { and the research } \\
\text { model. }\end{array}$ & $\begin{array}{l}\text { E.T.G. Wang, J.H.F. } \\
\text { Chen }\end{array}$ & ERP consulting process & $\begin{array}{l}\text { 1) Measures } \\
\text { 2) Data Analysis } \\
\text { 3) Top Management \& } \\
\text { User Support. }\end{array}$ \\
\hline $\begin{array}{l}\text { Different enterprise } \\
\text { systems (ES) }\end{array}$ & K.B. Hendricks et al. & $\begin{array}{l}\text { Pre implementation \& } \\
\text { Post implementation } \\
\text { period-ERP Systems. }\end{array}$ & $\begin{array}{l}\text { 1) Documents the effect } \\
\text { of investments in ERP, } \\
\text { SCM \& CRP. 2) } \\
\text { Application in SCM } \\
\text { system. }\end{array}$ \\
\hline $\begin{array}{l}\text { A theoretical } \\
\text { framework }\end{array}$ & $\begin{array}{l}\text { T. Srivardhana, S.D. } \\
\text { Pawlowski }\end{array}$ & Conceptual model & $\begin{array}{l}\text { 1) The model highlights } \\
\text { areas where active } \\
\text { management has potential } \\
\text { to enhance the } \\
\text { capabilities of a firm for } \\
\text { sustained innovation of } \\
\text { its business processes. }\end{array}$ \\
\hline $\begin{array}{l}\text { Structural equation } \\
\text { analysis }\end{array}$ & K.-Y. Kwahk, J.-N. Lee & $\begin{array}{l}\text { Research model \& } \\
\text { hypotheses }\end{array}$ & $\begin{array}{l}\text { 1) Analysis was } \\
\text { conducted to assess the } \\
\text { psychometric } \\
\text { properties of the scales. } \\
\text { 2) Model testing }\end{array}$ \\
\hline $\begin{array}{l}\text { Joint ventures, } \\
\text { networks and } \\
\text { Japanese-style } \\
\text { 'purchasing } \\
\text { partnership' \& } \\
\text { Sampling technique. }\end{array}$ & S.C.L. Koh et al. & $\begin{array}{l}\text { Primary Data, Secondary } \\
\text { Data \& Literature Survey }\end{array}$ & $\begin{array}{l}\text { 1) Collaboration } \\
\text { 2) Focus application } \\
\text { deployment on the } \\
\text { management of critical } \\
\text { relationships and key } \\
\text { performance metrics. } \\
\text { 3) Deploy internal } \\
\text { processes and enterprise } \\
\text { systems } \\
\text { 4) business intelligence } \\
\text { framework }\end{array}$ \\
\hline $\begin{array}{l}\text { Proposed model \& } \\
\text { strategic modeling }\end{array}$ & A. Hakim, H. Hakim & $\begin{array}{l}\text { Qualitative and } \\
\text { interpretive case study }\end{array}$ & $\begin{array}{l}\text { 1) Beneficial for the } \\
\text { organization. } \\
\text { 2) ERP as the corporate } \\
\text { strategic objective. }\end{array}$ \\
\hline $\begin{array}{l}\text { Statistics/ Statistical } \\
\text { technique. }\end{array}$ & W.-H. Tsai et al. & $\begin{array}{l}\text { Project Management \& } \\
\text { causal relationship of the } \\
\text { SERVQUAL. }\end{array}$ & $\begin{array}{l}\text { 1) Integrated into the } \\
\text { implementation and } \\
\text { measured by the } \\
\text { application of the service } \\
\text { quality (SERVQUAL). } \\
\text { 2) Facilitator. }\end{array}$ \\
\hline $\begin{array}{l}\text { ERPII, collaborative } \\
\text { networks, and the } \\
\text { extended enterprise. }\end{array}$ & S.C.L. Koh et al. & $\begin{array}{l}\text { Grounded } \\
\text { methodology }\end{array}$ & $\begin{array}{l}\text { 1) Combination of } \\
\text { descriptive } \\
\text { exploratory study. } \\
\text { 2) The results obtained } \\
\text { are analyzed to identify } \\
\text { the drivers and barriers }\end{array}$ \\
\hline
\end{tabular}




\begin{tabular}{|c|c|c|c|}
\hline & & & $\begin{array}{l}\text { for the ERPII } \\
\text { implementation, critical } \\
\text { success factors for ERP II } \\
\text { implementation and } \\
\text { future trends of ERP. }\end{array}$ \\
\hline $\begin{array}{l}\text { Information } \\
\text { integration } \\
\text { opportunity } \\
\text { assessment tool (IOP } \\
\text { tool). }\end{array}$ & Y. Kang et al. & $\begin{array}{l}\text { Algorithm in the IOP } \\
\text { Tool, RT } 258\end{array}$ & $\begin{array}{l}\text { 1) For locating } \\
\text { Market/legal hindrances } \\
\text { 2) Organizational and } \\
\text { process hindrances }\end{array}$ \\
\hline Coding /codification & I. Woungang et al. & $\begin{array}{l}\text { The survey-based } \\
\text { methodology }\end{array}$ & $\begin{array}{l}\text { 1) Testing, auditing and } \\
\text { tracking. } \\
\text { 2) In various } \\
\text { experiments. }\end{array}$ \\
\hline $\begin{array}{lr}\text { Robust } & \text { Exploratory } \\
\text { Factor } & \text { Analysis } \\
\text { (EFA) } & \end{array}$ & A. Amid et al. & $\begin{array}{l}\text { Conducting semi- } \\
\text { structured interviews, } \\
\text { instrument development, } \\
\text { data collection and data } \\
\text { analysis using robust } \\
\text { EFA }\end{array}$ & $\begin{array}{l}\text { 1) Discovers patterns of } \\
\text { multidimensional } \\
\text { constructs. } \\
\text { 2) Data interpretation and } \\
\text { empirical results. }\end{array}$ \\
\hline Transfer model & W.-H. Hung et al & $\begin{array}{l}\text { Literature review and } \\
\text { hypotheses }\end{array}$ & $\begin{array}{l}\text { 1) To integrate. } \\
\text { 2) Bonding } \\
\text { 3) Relationship bonding } \\
\text { in ERP implementation. }\end{array}$ \\
\hline
\end{tabular}

Table 7 : Frequency of Barriers of ERP from various Journals :

\begin{tabular}{|c|c|c|c|}
\hline Author(s) & Journal(s) & How many & \\
\hline & & 1 & 2 \\
\hline $\begin{array}{l}\text { Ike C. Ehie, } \\
\text { Mogen Madsen, } \\
2005\end{array}$ & Computers in Industry 56 (2005) 545-557 & $\sim$ & \\
\hline $\begin{array}{l}\text { Huigang Liang, } \\
\text { Yajiong Xue, } \\
2004\end{array}$ & 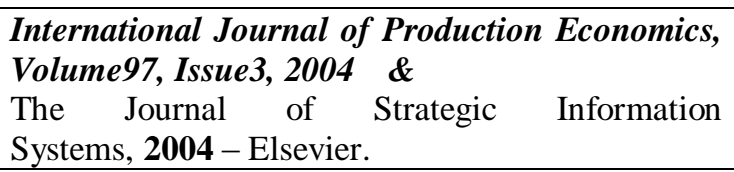 & & $\overline{-}$ \\
\hline $\begin{array}{l}\text { Elisabeth J Umble } \\
\text { Ronald R Haft, } \\
\text { M.Michael Umble, } \\
2003\end{array}$ & $\begin{array}{l}\text { European Journal of Operational Research } 146 \\
\text { (2003)241-257 }\end{array}$ & - & \\
\hline $\begin{array}{l}\text { Ramin Vandaie } \\
2008\end{array}$ & Knowledge-Based Systems 21 (2008) 920-926 & $\sim$ & \\
\hline $\begin{array}{l}\text { Davide Aloini, } \\
\text { Riccardo Dulmin, } \\
\text { Valeria Mininno, } \\
\quad 2012\end{array}$ & $\begin{array}{l}\text { European journal of operational research, } 2012 \\
\text { and } \\
\text { Business Process ..., } 2012\end{array}$ & & $\sim$ \\
\hline $\begin{array}{l}\text { AminAmid, } \\
\text { Morteza Moalagh, } \\
\text { Ahad Zare } \\
\text { Ravasan,2011 }\end{array}$ & Information Systems, 2011 - Elsevier & $=$ & \\
\hline $\begin{array}{l}\text { Yi-fen Su, } \\
\text { Chyan Yang }\end{array}$ & $\begin{array}{l}\text { Expert Systems with Applications } \\
\text { Volume 37, Issue 1, January } 2010 .\end{array}$ & - & \\
\hline $\begin{array}{l}\text { Yajiong Xue } \\
\text { Huigang Liang }^{\mathrm{b}}, \\
\text { William R. } \\
\text { Boulton }^{\mathrm{c}}, \\
\text { Charles A. Snyder , } \\
2005\end{array}$ & $\begin{array}{l}\text { International Journal of Production Economics } \\
\text { Volume } 97, \text { Issue 3, September } 2005\end{array}$ & $\sim$ & \\
\hline
\end{tabular}




\begin{tabular}{|c|c|c|}
\hline $\begin{array}{l}\text { Vincent } \\
\text { Mabert1, Ashok } \\
\text { Soni, } \\
\text { M.A. } \\
\text { Venkataramanan } \\
\text { 2006. }\end{array}$ & $\begin{array}{l}\text { Mathematical and Computer Modelling } \\
\text { Volume 44, Issues 1-2, July } 2006\end{array}$ & - \\
\hline $\begin{array}{l}\text { Salvador Bueno, } \\
\text { Jose L. Salmeron } \\
2008\end{array}$ & Interacting with Computers, $\mathbf{2 0 0 8}$ - Elsevier & - \\
\hline $\begin{array}{l}\text { Yan Zhu, } \\
\text { Yan Li, } \\
\text { Weiquan Wang, } \\
\text { Jian Chen } \\
2010\end{array}$ & $\begin{array}{l}\text { International Journal of Information } \ldots, \mathbf{2 0 1 0} \text { - } \\
\text { Elsevier }\end{array}$ & $\sigma$ \\
\hline $\begin{array}{l}\text { Mary C. Jones, } \\
\text { Melinda Cline, } \\
\text { Sherry Ryan, } \\
2006\end{array}$ & $\begin{array}{l}\text { Decision Support Systems, } 2006 \\
\text { Volume 41, Issue } 2 .\end{array}$ & $\sigma$ \\
\hline $\begin{array}{l}\text { Wen-Hsien Tsai et } \\
\text { al. } \\
2012\end{array}$ & $\begin{array}{l}\text { Decision Support Systems archive } \\
\text { Volume } 50 \text { Issue 2, January, } 2011\end{array}$ & - \\
\hline $\begin{array}{lr}\text { 1. Boo } & \text { Young } \\
\text { Chung } & 2 . \\
\text { Mirosław } & \text { J. } \\
\text { Skibniewski } \\
\text { 3. Henry C. Lucas } \\
\text { Jr.; \& 4. Young } \\
\text { Hoon Kwak 2008 } \\
\end{array}$ & $\begin{array}{lccrr}\text { JOURNAL } & \text { OF } & \text { COMPUTING } & \text { IN } & \text { CIVIL } \\
\text { ENGINEERING } & \odot & \text { ASCE } & / \\
\text { NOVEMBER/DECEMBER } 2008 & & \end{array}$ & - \\
\hline S.C.L. Koh et al. & $\begin{array}{l}\text { International Journal of Production ..., } 2008- \\
\text { Elsevier and } \\
\text { International Journal of Production Economics } \\
\text { Volume 113, Issue 1, May 2008, Pages 245-268 }\end{array}$ & \\
\hline $\begin{array}{l}\text { A. Hakim, H. } \\
\text { Hakim }\end{array}$ & Information Systems, 2010 - Elsevier. & - \\
\hline
\end{tabular}

Table 8: Details of Literature Search:

\begin{tabular}{|c|c|c|c|c|c|}
\hline $\begin{array}{l}\text { Review } \\
\text { Period }\end{array}$ & Time & Search Engines & Primary Keywords & $\begin{array}{l}\text { Secondary } \\
\text { Keywords }\end{array}$ & $\begin{array}{l}\text { Secondary } \\
\text { Keywords }\end{array}$ \\
\hline & & & & Keywords Group:1 & Keywords Group:2 \\
\hline $\begin{array}{l}\text { From } \\
1997\end{array}$ & $1992-$ & ScienceDirect & $\begin{array}{l}\text { Enterprise } \text { Resource } \\
\text { Planning }\end{array}$ & ERP Database & ERP Solution \\
\hline $\begin{array}{l}\text { From } \\
2002\end{array}$ & 1998- & ScienceDirect & $\begin{array}{l}\text { Enterprise Resource } \\
\text { Planning } \\
\text { ERP systems, } \\
\text { Organizational fit. }\end{array}$ & $\begin{array}{lr}\text { ERP, } & \text { Business } \\
\text { Modeling, } & \text { Process } \\
\text { model, } & \text { Returned } \\
\text { materials, } & \text { Process } \\
\text { adaptation. }\end{array}$ & $\begin{array}{l}\text { SAP, Integration } \\
\text { and performance, } \\
\text { SAP R/3, Organzl. } \\
\text { Resistance. }\end{array}$ \\
\hline $\begin{array}{l}\text { From } \\
2008\end{array}$ & $2003-$ & $\begin{array}{l}\text { ScienceDirect \& } \\
\text { Googlescholar }\end{array}$ & $\begin{array}{l}\text { Enterprise Resource } \\
\text { Planning, } \\
\text { ERP system, } \\
\text { Information systems, } \\
\text { TAM (Technology } \\
\text { Acceptance Model), } \\
\text { Manufacturing firms, } \\
\text { ERP failure, } \\
\text { ERP implementation, }\end{array}$ & $\begin{array}{l}\text { ERP, BPR, } \\
\text { Improvement, } \\
\text { Implementation, } \\
\text { ERP systems } \\
\text { implementation, } \\
\text { Linguistic } \\
\text { modeling, Review, } \\
\text { Operations strategy, } \\
\text { Decision }\end{array}$ & $\begin{array}{l}\text { Survey, } \\
\text { Organizational } \\
\text { issues, Case study, } \\
\text { Critical success } \\
\text { factors, Information } \\
\text { processing, SME, } \\
\text { Optimization, Case } \\
\text { studies, Simulation } \\
\text { Case research, AHP, }\end{array}$ \\
\hline
\end{tabular}




\begin{tabular}{|c|c|c|c|c|}
\hline & & $\begin{array}{l}\text { Benefits, } \\
\text { Organizational } \\
\text { knowledge sharing, } \\
\text { Organizational } \\
\text { innovation, Survey } \\
\text { data, Logistic } \\
\text { models, Knowledge } \\
\text { transfer, Perceived } \\
\text { usefulness, Risk } \\
\text { management, ERP } \\
\text { benefit, Case study, } \\
\text { Enterprise } \\
\text { application } \\
\text { integration, Supply } \\
\text { chain management, } \\
\text { Information system, } \\
\text { Enterprise system } \\
\text { implementation, } \\
\text { Technology adoption, } \\
\text { Enterprise modeling } \\
\text { Verification. }\end{array}$ & $\begin{array}{l}\text { analysis, Training, } \\
\text { System integration } \\
\text { Manufacturing, } \\
\text { Success factors, } \\
\text { Information } \\
\text { systems, Operations } \\
\text { management, } \\
\text { Project mgmt, } \\
\text { Survey } \\
\text { methodology, } \\
\text { Questionnaire } \\
\text { survey, Risk mgmt. } \\
\text { Historical } \\
\text { perspective, } \\
\text { Decision support, } \\
\text { Critical success } \\
\text { factors, } \\
\text { Organizational } \\
\text { culture, Balanced } \\
\text { scorecard, IS/IT } \\
\text { selection, } \\
\text { Packaged software } \\
\text { User participation, } \\
\text { Logistic models, } \\
\text { Regression analysis, } \\
\text { Discriminate Users' } \\
\text { analysis, I Use } \\
\text { absorptive capacity, } \\
\text { Ease of use, } \\
\text { Literature analysis, } \\
\text { Segment, } \\
\text { Supplier evaluation, } \\
\text { Consistency, } \\
\text { Lifecycle, Erp } \\
\text { systems, Planning } \\
\text { process, MRP } \\
\text { activity, Orgnzl. } \\
\text { Knowledge mgmt., } \\
\text { Triandis model, } \\
\text { Validation, } \\
\text { Certification. }\end{array}$ & $\begin{array}{l}\text { Information system, } \\
\text { Communication, } \\
\text { Healthcare, Rolls- } \\
\text { Royce, Frameworks, } \\
\text { Alignment, } \\
\text { Implementation } \\
\text { procedures, } \\
\text { Logistic regression } \\
\text { models, } \\
\text { Swedish industry, } \\
\text { Social-cultural } \\
\text { perspective, } \\
\text { Ensemble view, } \\
\text { Impacts, } \\
\text { Objectives, } \\
\text { Literature review, } \\
\text { ERP, Delphi method } \\
\text { Customization, } \\
\text { Systems integration, } \\
\text { Data envelopment } \\
\text { analysis(DEA), } \\
\text { Organizational } \\
\text { support, Users' } \\
\text { performance of ERP } \\
\text { usage, } \\
\text { Technology } \\
\text { acceptance, User } \\
\text { involvement, ERP } \\
\text { life-cycle, Risk } \\
\text { assessment, Rough } \\
\text { set theory, } \\
\text { Contract } \\
\text { negotiation, } \\
\text { Contractor, } \\
\text { Infrastructure, } \\
\text { Delphi study, Firm } \\
\text { processes, Firm } \\
\text { performance, Tacit } \\
\text { knowledge, Survey } \\
\text { Qualification. }\end{array}$ \\
\hline $\begin{array}{l}\text { From 2009- } \\
2012\end{array}$ & $\begin{array}{l}\text { ScienceDirect \& } \\
\text { Googlescholar }\end{array}$ & $\begin{array}{l}\text { Enterprise } \\
\text { Planning, Resource } \\
\text { system(s), ERP } \\
\text { Maintenance, SCM, } \\
\text { Decision making, } \\
\text { Coding defects, } \\
\text { Generic product } \\
\text { model (GPM), ERP } \\
\text { system, Fuzzy AHP, } \\
\text { ERP project, } \\
\text { Information system, } \\
\text { ERP, CSFs, Project } \\
\text { preparedness, Risk } \\
\text { factors inter- } \\
\text { dependence, } \\
\text { Technology adoption, } \\
\text { Imitation. }\end{array}$ & 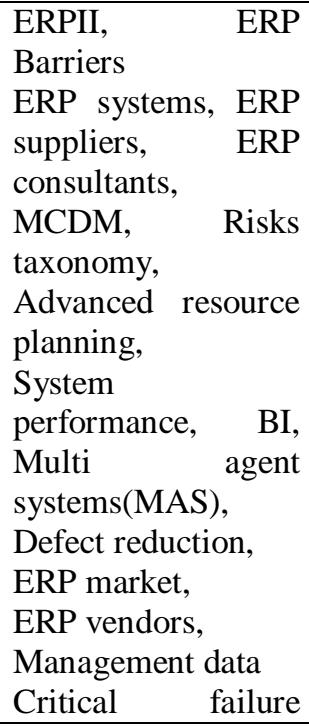 & $\begin{array}{l}\text { Selection criteria, } \\
\text { Supplier selection, } \\
\text { AHP Hierarchy, } \\
\text { SEM, Stochastic } \\
\text { models, System } \\
\text { vendor, } \\
\text { Implementation } \\
\text { consultant, } \\
\text { Petri Nets(PN), } \\
\text { Software selection } \\
\text { Software testing, } \\
\text { ERP selection } \\
\text { model, Grounded } \\
\text { theory, Information } \\
\text { sharing, for } \\
\text { RFP(Request for } \\
\text { proposal), Robust } \\
\text { Exploratory factor }\end{array}$ \\
\hline
\end{tabular}




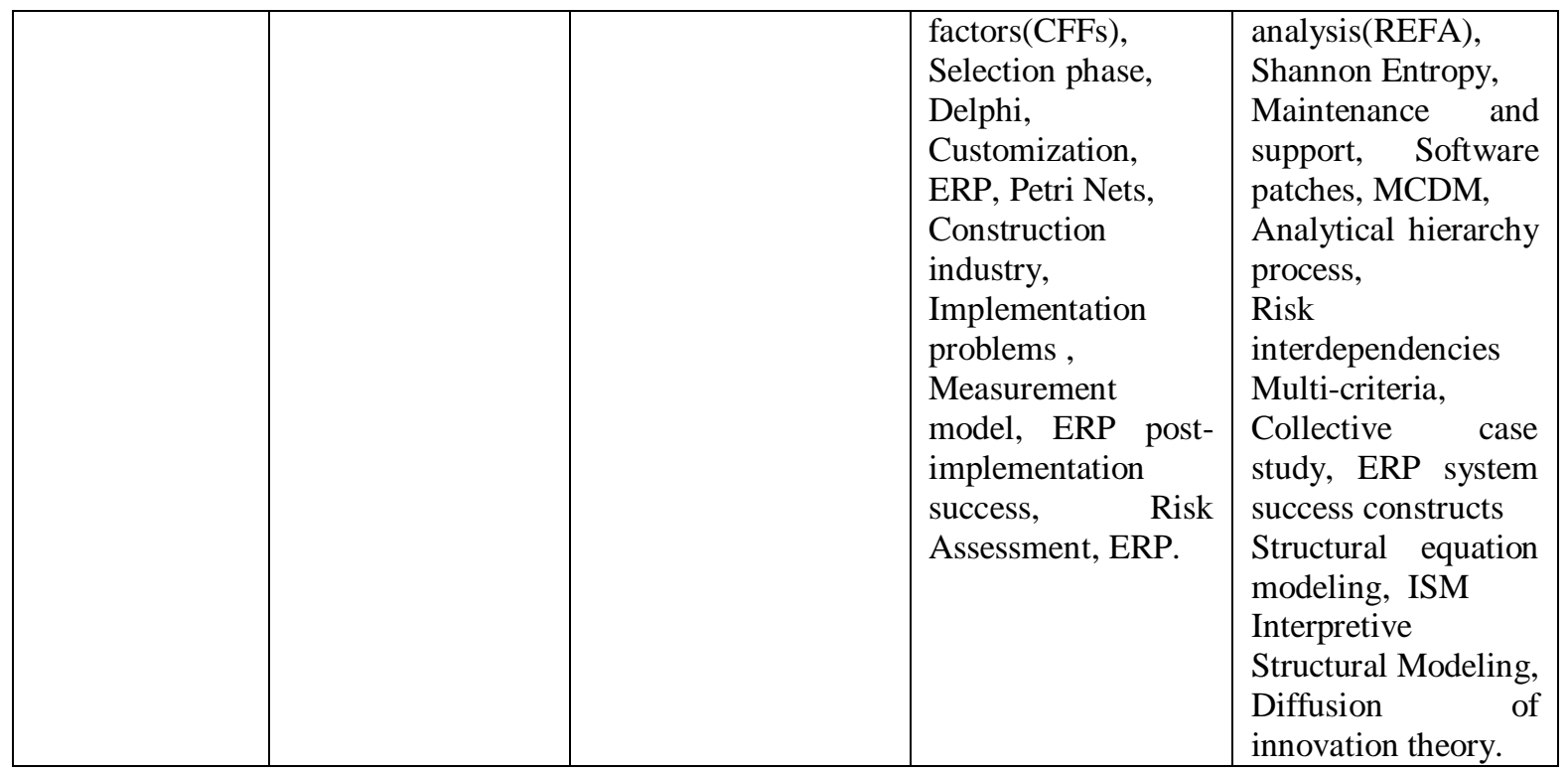

Table 9 : Summary of the barriers for effective implementation of ERP :

\begin{tabular}{|c|c|c|c|}
\hline $\begin{array}{l}\text { Barrier } \\
\text { Code }\end{array}$ & Description of Barrier & References & $\begin{array}{l}\text { Total of } \\
\text { References \# }\end{array}$ \\
\hline B1 & $\begin{array}{l}\text { Lack of perfection for effective } \\
\text { implementation. } \\
\text { Lack of software acquisition process } \\
\text { and complexities. } \\
\text { Lack of the reactivity of the planning } \\
\text { system. }\end{array}$ & $\begin{array}{l}\text { Ike C. Ehie ,Mogen Madsen, } \\
2005 \\
\text { Jacques Verville, Alannah } \\
\text { Halingten ,2003 } \\
\text { Claire Berchet,Georges Habchi, } \\
2005\end{array}$ & 3 \\
\hline B2 & $\begin{array}{l}\text { Lack of the reactivity of the planning } \\
\text { system . } \\
\text { Lack of Structured GPM data. } \\
\text { Lack of organizational barriers. }\end{array}$ & $\begin{array}{l}\text { Elisabeth J Umble a, Ronald R } \\
\text { Haft, M.Michael Umble,2003 } \\
\text { Souleiman Naciri et al.,2011 } \\
\text { Boonserm } \\
\text { Kulvatunyou, Richard A. Wysk, } \\
2000\end{array}$ & 3 \\
\hline B3 & Lack of Contextual issues. & $\begin{array}{l}\text { Huigang Liang, } \\
\text { Yajiong Xue, } \\
2004\end{array}$ & 1 \\
\hline B4 & Lack of management of knowledge & Ramin Vandaie, 2008 & 1 \\
\hline B5 & $\begin{array}{l}\text { Lack of approach \& risk assessment. } \\
\text { Lack of Critical success factors. } \\
\text { Lack of data analysis. }\end{array}$ & $\begin{array}{l}\text { Davide Aloini, Riccardo } \\
\text { Dulmin ,Valeria Mininno,2012. } \\
\text { Joseph Bradley, 2008. } \\
\text { AminAmid, Morteza Moalagh, } \\
\text { Ahad Zare Ravasan,2012. }\end{array}$ & 4 \\
\hline B6 & $\begin{array}{l}\text { Lack of ERP systems benefit . } \\
\text { Lack of firm competences }\end{array}$ & $\begin{array}{l}\text { Daniel E. O’Leary,2005 } \\
\text { Yi-fen Su, Chyan Yang, } \\
2010\end{array}$ & 2 \\
\hline
\end{tabular}


Barriers of ERP while implementing ERP : A Literature Review

\begin{tabular}{|c|c|c|c|}
\hline B7 & Lack of data models & Daniel E. O’Leary, 2005 & 1 \\
\hline B8 & $\begin{array}{l}\text { Foreign ERP vendors have failed } \\
\text { (lack of good vendors) } \\
\text { Lack of augmentation. } \\
\text { Lack of critical factors }\end{array}$ & $\begin{array}{l}\text { Yajiong Xue, Huigang Liang } \\
\text { William R. Boulton }^{c}, \\
\text { Charles A. Snyder , } 2005 \\
\text { Vincent A. Mabert1, Ashok Soni, } \\
\text { M.A. Venkataramanan } \\
2006 . \\
\text { Boo Young Chung } \\
\text { Mirosław J. Skibniewski, } \\
\text { Henry C. Lucas Jr.; \& Young } \\
\text { Hoon Kwak, 2008 }\end{array}$ & 3 \\
\hline B9 & Lack of passive learning & DESHPANDE, AMIT A. ,2008 & 1 \\
\hline $\mathrm{B} 10$ & Lack of complementary control & $\begin{array}{l}\text { Severing V. Grabski }{ }^{\mathrm{a}} \text {, } \\
\text { Stewart A. Leech, } 2007\end{array}$ & 1 \\
\hline B11 & $\begin{array}{l}\text { Lack of multi-method analysis. } \\
\text { Lack of conceptual framework. } \\
\text { Lack of both imitative and logical } \\
\text { evaluation forces. }\end{array}$ & $\begin{array}{l}\text { Craig Shepherd }{ }^{1} \text {,Chris } \text { Clegg }^{2} \text { and } \\
\text { Chris S tride } \\
\text { Petri Hallikainen , Hannu } \\
\text { Kivijärvi , Markku Tuominen }{ }^{\underline{b}} \text {, } \\
2009 \\
\text { Vincent S. Lai,Connie K.W. Liu, } \\
\text { Fujun Lai, Jian Wang, } 2010\end{array}$ & 3 \\
\hline B12 & $\begin{array}{l}\text { Lack of group cohesion } \\
\text { Lack of post-implementation } \\
\text { success. }\end{array}$ & $\begin{array}{l}\text { Eric T.G. Wang, Ta-Chung Ying, } \\
\text { James J. Jiang, Gary Klein, } 2006 \\
\text { Yan Zhu, Yan Li, Weiquan } \\
\text { Wang, Jian Chen, } 2010\end{array}$ & 2 \\
\hline B13 & Lack of decisive factors & $\begin{array}{llll}\text { Salvador } & \text { Bueno, } & \text { Jose } & \text { L. } \\
\text { Salmeron } 2008 & & \end{array}$ & 1 \\
\hline B14 & Lack of engines of economic growth. & Helena Lenihan , 2011 & 1 \\
\hline B15 & $\begin{array}{l}\text { Lack of consulting fees. } \\
\text { Lack of hierarchical attribute } \\
\text { structure. }\end{array}$ & $\begin{array}{l}\text { Malgorzata Plazas, Katrin Rohlf } \\
2008 \\
\text { Chun-Chin Wei, Mao-Jiun J. } \\
\text { Wang, 2004 }\end{array}$ & 2 \\
\hline B16 & Lack of activities & $\begin{array}{l}\text { V. Chapurlat, C. Braesch } \\
2008\end{array}$ & 1 \\
\hline B17 & $\begin{array}{l}\text { Lack of modeling \& ERP's system } \\
\text { functionality. }\end{array}$ & $\begin{array}{l}\text { Pnina Soffer,.Boaz Golany, Dov } \\
\text { Dori } 2003\end{array}$ & 1 \\
\hline B18 & $\begin{array}{l}\text { Lack of business, cultural and } \\
\text { technical issues. }\end{array}$ & $\begin{array}{l}\text { Yahaya Yusuf, A Gunasekaran, } \\
\text { Mark S Abthorpe } 2004\end{array}$ & 1 \\
\hline B19 & $\begin{array}{l}\text { Lack of cultural barriers } \\
\text { Lack of expert tool. }\end{array}$ & $\begin{array}{l}\text { Mary C. Jones, Melinda Cline, } \\
\text { Sherry Ryan, } 2006 \\
\text { M. Ghazanfari ,M. Jafari ,S. } \\
\text { Rouhani, } 2011\end{array}$ & 2 \\
\hline & $\begin{array}{l}\text { Lack of acceptance factors. } \\
\text { Lack of theoretical bases and inter- } \\
\text { organizational relationships. } \\
\text { Lack of challenges. } \\
\text { Lack of social factors. }\end{array}$ & $\begin{array}{l}\frac{\text { Adam, R ,Van der Merwe, A }}{2011} \\
\text { Andreas I. Nicolaou, } 2008 \\
\text { Jim Odhiambo Otieno, } 2011 \\
\text { Man-Kit Chang, Waiman }\end{array}$ & \\
\hline
\end{tabular}




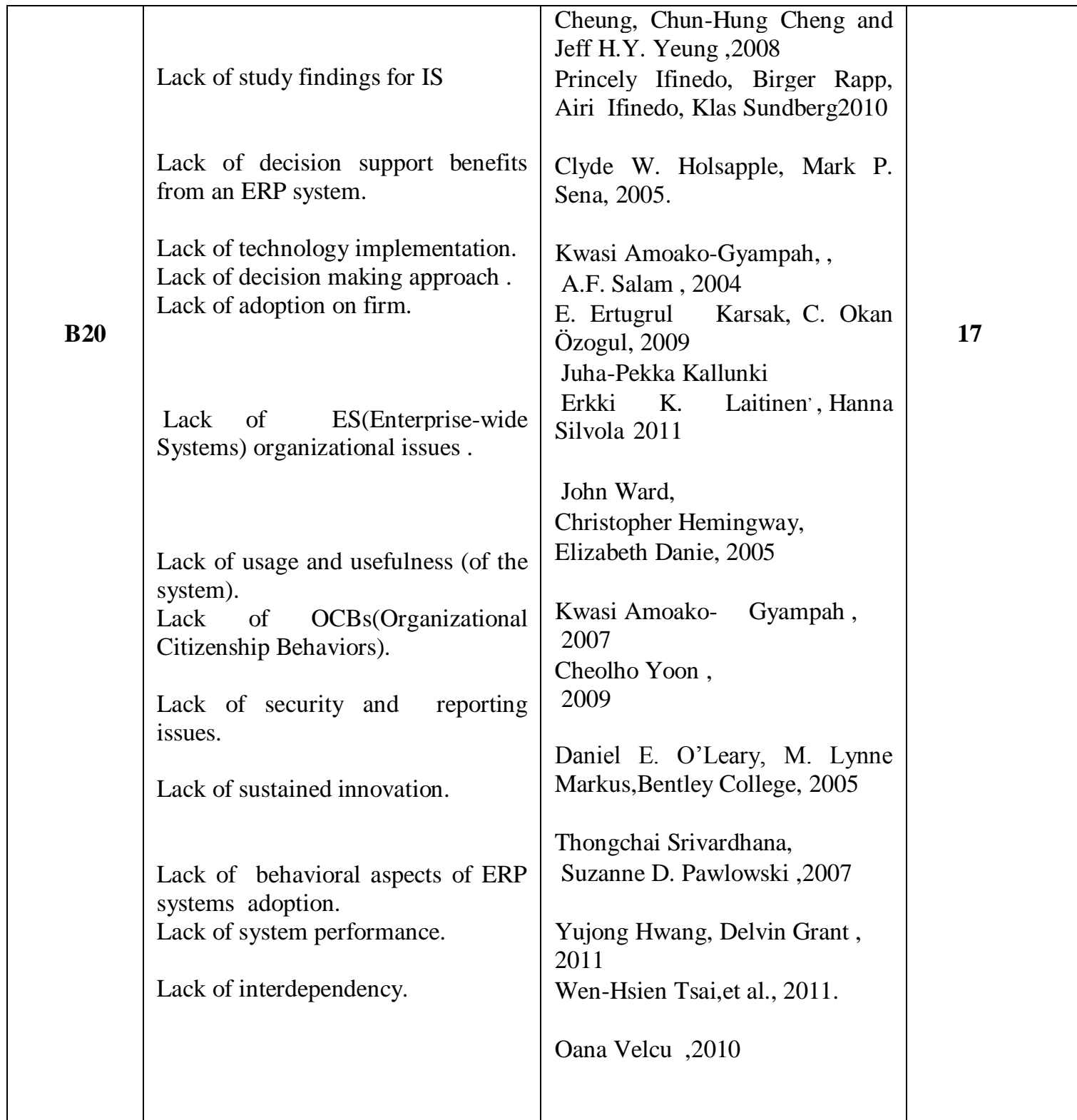

Table 10 : Classification of Literature Review Research Paper :

\begin{tabular}{|c|c|c|c|c|c|c|c|}
\hline S.N. & $\begin{array}{l}\text { Author } \\
\text { (Year) }\end{array}$ & $\begin{array}{l}\text { Research } \\
\text { Methodolo } \\
\text { gy }\end{array}$ & Samples & $\begin{array}{l}\text { Indust } \\
\text { ry }\end{array}$ & Country & $\begin{array}{l}\text { Research } \\
\text { Objective/ } \\
\text { Focus }\end{array}$ & $\begin{array}{l}\text { Main } \\
\text { Findings/ } \\
\text { CSFs }\end{array}$ \\
\hline 1. & $\begin{array}{l}\text { Ike C. } \\
\text { Ehie, } \\
\text { Mogen } \\
\text { Madse } \\
\text { n, } \\
2005\end{array}$ & $\begin{array}{l}\text { A five- } \\
\text { stage ERP } \\
\text { implementa } \\
\text { tion } \\
\text { process. } \\
\text { (1) the } \\
\text { retest } \\
\text { method, (2) } \\
\text { the } \\
\text { alternative } \\
\text { form } \\
\text { method, (3) } \\
\text { the } \\
\text { splithalves } \\
\text { method, }\end{array}$ & $\begin{array}{l}200 \\
\text { questionn } \\
\text { aires. } \\
\text { e.g. } \\
\text { Unisource } \\
\text { Worldwid } \\
\text { e, Inc. } \\
\text { The } \\
\text { Earthgrain } \\
\text { s } \\
\text { Company } \\
\text {. IBM, } \\
\text { DaimlerB } \\
\text { enz and } \\
\text { Chrysler }\end{array}$ & $\begin{array}{l}200 \\
\text { ERP } \\
\text { Softw } \\
\text { are } \\
\text { indust } \\
\text { ries. }\end{array}$ & U.S.A. & $\begin{array}{l}\text { The } \\
\text { objective is } \\
\text { to determine } \\
\text { the extent to } \\
\text { which } \\
\text { the identified } \\
\text { critical } \\
\text { factors } \\
\text { correlate } \\
\text { with ERP } \\
\text { implementati } \\
\text { on. }\end{array}$ & $\begin{array}{l}\text { The study } \\
\text { reveals that } \\
\text { about } 86.3 \% \\
\text { of the } \\
\text { variances in } \\
\text { ERP } \\
\text { implementat } \\
\text { ion } \\
\text { were } \\
\text { explained by } \\
\text { the critical } \\
\text { factors } \\
\text { identified in } \\
\text { the } \\
\text { study. }\end{array}$ \\
\hline
\end{tabular}




\begin{tabular}{|c|c|c|c|c|c|c|c|}
\hline & & $\begin{array}{l}\text { and (4) the } \\
\text { internal } \\
\text { consistency } \\
\text { method } \\
{[36] \text {. }}\end{array}$ & Etc. & & & & \\
\hline 2. & $\begin{array}{l}\text { Jacque } \\
\text { s } \\
\text { Vervill } \\
\text { e, } \\
\text { Alanna } \\
\text { h } \\
\text { Haling } \\
\text { ten, } \\
2003\end{array}$ & $\begin{array}{l}\text { ERP } \\
\text { Software } \\
\text { Acquisition } \\
\text { Process. }\end{array}$ & $\begin{array}{l}\text { It is not } \\
\text { generaliza } \\
\text { ble to a } \\
\text { larger } \\
\text { population } \\
\text {. }\end{array}$ & $\begin{array}{l}50 \\
\text { China } \\
\text { Indust } \\
\text { ries. }\end{array}$ & China & $\begin{array}{l}\text { To depict the } \\
\text { principal } \\
\text { processes } \\
\text { that pertain } \\
\text { to the } \\
\text { acquisition } \\
\text { of packaged } \\
\text { software. }\end{array}$ & $\begin{array}{l}\text { Presented a } \\
\text { model of the } \\
\text { ERP } \\
\text { software } \\
\text { acquisition } \\
\text { process } \\
\text { (MERPAP) } \\
\text { that reflects } \\
\text { the findings } \\
\text { from the } \\
\text { four cases } \\
\text { examined in } \\
\text { this study. }\end{array}$ \\
\hline 3. & $\begin{array}{l}\text { Claire } \\
\text { Berche } \\
\mathrm{t}, \\
\text { George } \\
\mathrm{s} \\
\text { Habchi } \\
\\
2005\end{array}$ & $\begin{array}{l}\text { Five-stage } \\
\text { deployment } \\
\text { model }\end{array}$ & $\begin{array}{l}\text { System } \\
\text { based on } \\
\text { performan } \\
\text { ce } \\
\text { indicators. }\end{array}$ & $\begin{array}{l}\text { Alcate } \\
1\end{array}$ & France & $\begin{array}{l}\text { To develop } \\
\text { a control } \\
\text { helping } \\
\text { system based } \\
\text { on } \\
\text { performance } \\
\text { indicators. }\end{array}$ & $\begin{array}{l}\text { A detailed } \\
\text { model of the } \\
\text { planning } \\
\text { process is } \\
\text { built. } \\
\text { Outline the } \\
\text { main results } \\
\text { obtained at } \\
\text { Alcatel in a } \\
\text { general way, } \\
\text { and describe } \\
\text { the risks, the } \\
\text { dysfunctions } \\
\text { and the } \\
\text { reasons for } \\
\text { them. }\end{array}$ \\
\hline 4. & $\begin{array}{l}\text { Elisabe } \\
\text { th J } \\
\text { Umble } \\
\text { a , Rona } \\
\text { ld R } \\
\text { Haft, } \\
\text { M.Mic } \\
\text { hael } \\
\text { Umble } \\
\text { 2003 }\end{array}$ & Case study & $\begin{array}{l}\text { Multi-site } \\
\text { issues. }\end{array}$ & $\begin{array}{l}\text { Huck } \\
\text { Intern } \\
\text { ational } \\
\text {, Inc. }\end{array}$ & U.S.A. & $\begin{array}{l}\text { The } \\
\text { objective is } \\
\text { to see why } \\
\text { and how } \\
\text { Implementati } \\
\text { on of ERP } \\
\text { fails? }\end{array}$ & $\begin{array}{l}\text { This article } \\
\text { identifies } \\
\text { success } \\
\text { factors, } \\
\text { software } \\
\text { selection } \\
\text { steps, and } \\
\text { implementat } \\
\text { ion } \\
\text { procedures } \\
\text { critical to a } \\
\text { successful } \\
\text { implementat } \\
\text { ion }\end{array}$ \\
\hline 5. & $\begin{array}{l}\text { Soulei } \\
\text { man } \\
\text { Naciri } \\
\text { et al. } \\
2011\end{array}$ & $\begin{array}{l}\text { GPM(Gen } \\
\text { ericProduct } \\
\text { Model. }\end{array}$ & $\begin{array}{l}\text { Two case } \\
\text { studies }\end{array}$ & $\begin{array}{l}\text { Hitach } \\
\mathrm{i} \\
\text { Comp } \\
\text { any }\end{array}$ & $\begin{array}{l}\text { Switzer } \\
\text { land. }\end{array}$ & $\begin{array}{l}\text { To establish } \\
\text { framework } \\
\text { and to } \\
\text { collect } \\
\text { Structured } \\
\text { GPM data. }\end{array}$ & $\begin{array}{l}\text { The } \\
\text { proposed } \\
\text { framework } \\
\text { enables data } \\
\text { management } \\
\text { contained in } \\
\text { flat Excel } \\
\text { Files to be } \\
\text { translated } \\
\text { into }\end{array}$ \\
\hline
\end{tabular}




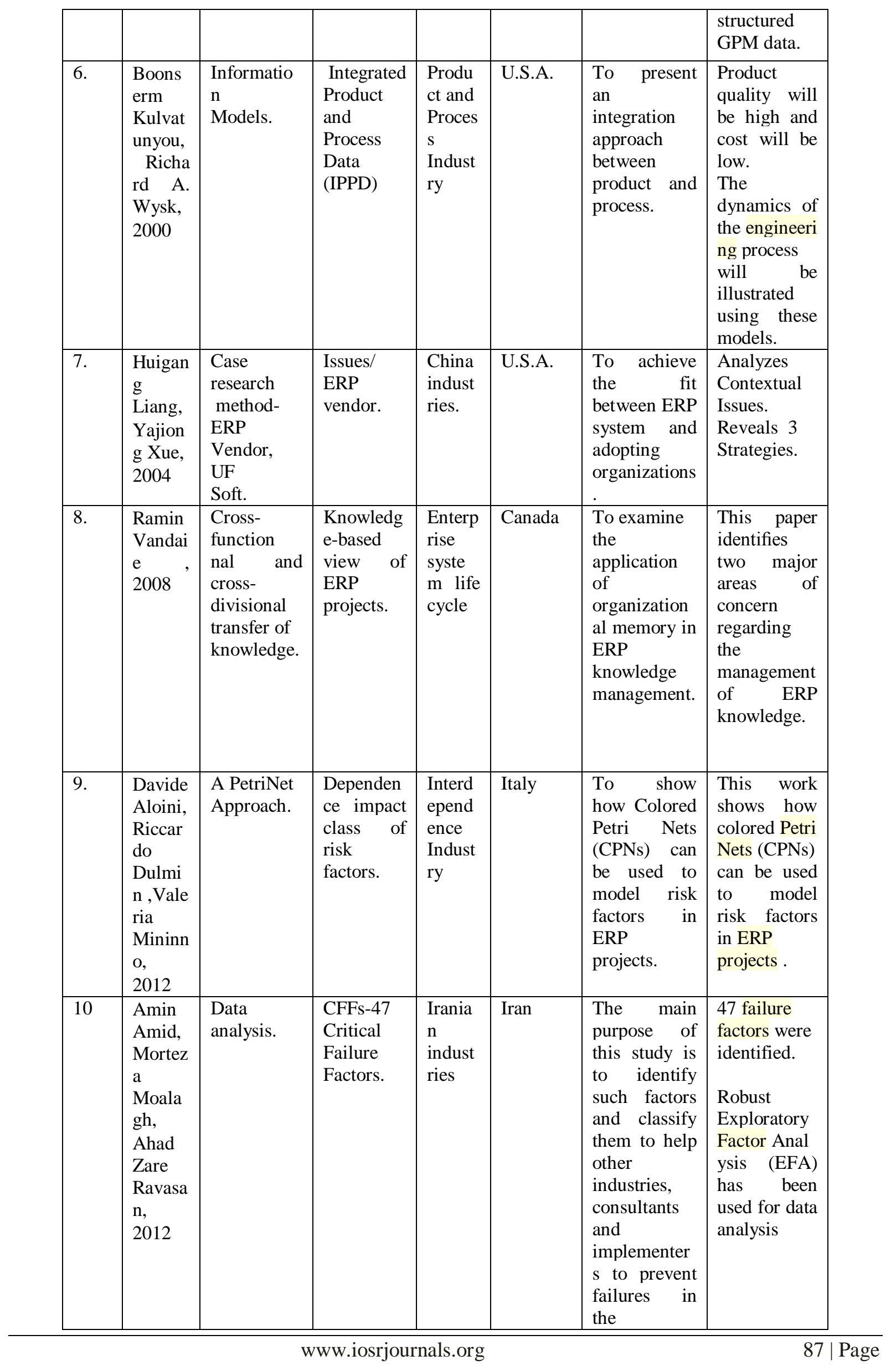




\begin{tabular}{|c|c|c|c|c|c|c|c|}
\hline & & & & & & $\begin{array}{l}\text { implementati } \\
\text { on of ERP } \\
\text { projects. }\end{array}$ & \\
\hline 11 & $\begin{array}{l}\text { Davide } \\
\text { Aloini, } \\
\text { Riccar } \\
\text { do } \\
\text { Dulmi } \\
\text { n, Vale } \\
\text { ria } \\
\text { Mininn } \\
\text { o, } \\
2012\end{array}$ & $\begin{array}{l}\text { Classificati } \\
\text { on \& } \\
\text { Analyze. }\end{array}$ & $\begin{array}{l}\text { Innovative } \\
\text { Technique } \\
- \\
\text { Risk } \\
\text { Analysis }\end{array}$ & $\begin{array}{l}\text { ERP } \\
\text { Indust } \\
\text { ry }\end{array}$ & Italy & $\begin{array}{l}\text { To highlight } \\
\text { the key risk } \\
\text { factors and } \\
\text { their impact } \\
\text { on project } \\
\text { success. }\end{array}$ & $\begin{array}{l}\text { Literature } \\
\text { was } \\
\text { classified in } \\
\text { order to } \\
\text { address and } \\
\text { analyze each } \\
\text { risk factor } \\
\text { and its } \\
\text { relevance } \\
\text { during the } \\
\text { stages of the } \\
\text { ERP project } \\
\text { life cycle. }\end{array}$ \\
\hline 12 & $\begin{array}{l}\text { Joseph } \\
\text { Bradle } \\
\text { y, } \\
2008 \text {. }\end{array}$ & $\begin{array}{l}\text { This study } \\
\text { is a } \\
\text { review of } \\
\text { literature } \\
\text { on } \\
\text { ERP. } \\
\text { (ABI } \\
\text { Inform, } \\
\text { Emerald, } \\
\text { ScienceDir } \\
\text { ect } \\
\text { and ACM } \\
\text { Digital } \\
\text { Library). }\end{array}$ & $\begin{array}{l}\text { Based on } \\
\text { the } \\
\text { Classical } \\
\text { Managem } \\
\text { ent } \\
\text { Theory. }\end{array}$ & $\begin{array}{l}\text { Case } \\
\text { study } \\
\text { compa } \\
\text { nies }\end{array}$ & $\begin{array}{l}\text { Moscow } \\
\text { ID, } \\
\text { United } \\
\text { States }\end{array}$ & $\begin{array}{l}\text { To examine } \\
\text { critical } \\
\text { success } \\
\text { factors for } \\
\text { implementin } \\
\mathrm{g} \text { Enterprise } \\
\text { Resource } \\
\text { Planning } \\
\text { systems. }\end{array}$ & $\begin{array}{l}\text { Project } \\
\text { success. } \\
\text { Integration } \\
\text { of ERP } \\
\text { planning } \\
\text { with } \\
\text { business } \\
\text { planning. }\end{array}$ \\
\hline 13 & $\begin{array}{l}\text { Daniel } \\
\text { E. } \\
\text { O'Lear } \\
\text { y, } \\
2005\end{array}$ & $\begin{array}{l}\text { ERP } \\
\text { Database }\end{array}$ & $\begin{array}{l}\text { Use of } \\
\text { consultant } \\
\mathrm{s}\end{array}$ & $\begin{array}{l}\text { Deloit } \\
\text { te } \\
\text { Consu } \\
\text { lting }\end{array}$ & $\begin{array}{l}\text { Californi } \\
\text { a , } \\
\text { U.S.A. }\end{array}$ & $\begin{array}{l}\text { To calculate } \\
\text { the tangible } \\
\text { and } \\
\text { intangible } \\
\text { benefits in } \\
\text { case of } \\
\text { industries. }\end{array}$ & $\begin{array}{l}\text { Some } \\
\text { benefits vary } \\
\text { by industry. } \\
\text { Statistically } \\
\text { consistent. } \\
\text { Tangible } \\
\text { benefits are } \\
\text { largely } \\
\text { industry dep } \\
\text { endent. }\end{array}$ \\
\hline 14 & $\begin{array}{l}\text { Yi-fen } \\
\text { Su, } \\
\text { Chyan } \\
\text { Yang, } \\
2010\end{array}$ & $\begin{array}{l}\text { SEM } \\
\text { (Structural } \\
\text { Equation } \\
\text { Modeling) }\end{array}$ & $\begin{array}{l}\text { Model- } \\
\text { process } \\
\& \\
\text { hypothese } \\
\text { s. }\end{array}$ & $\begin{array}{l}\text { Taiwa } \\
\text { nese } \\
\text { IT } \\
\text { firms }\end{array}$ & Taiwan & $\begin{array}{l}\text { To find out } \\
\text { the } \\
\text { Benefits } \\
\text { derived from } \\
\text { various } \\
\text { integration } \\
\text { process. }\end{array}$ & $\begin{array}{l}\text { Beneficial i } \\
\text { mpacts of E } \\
\text { RP on the } \\
\text { supply } \\
\text { chain. } \\
\text { Enhance } \\
\text { firm } \\
\text { competences } \\
\text { of SCM. }\end{array}$ \\
\hline 15 & $\begin{array}{l}\text { Yajion } \\
\mathrm{g} \text { Xue, } \\
\text { Huigan } \\
\mathrm{g} \\
\text { Liang } \\
\text { Willia } \\
\mathrm{m} \quad \mathrm{R} . \\
\text { Boulto } \\
\mathrm{n}^{\mathrm{c}}, \\
2005\end{array}$ & $\begin{array}{l}\text { Case study- } \\
\text { - Hi } \\
\text { storical } \\
\text { perspective }\end{array}$ & $\begin{array}{l}\text { Case } \\
\text { studies } \\
\text { from } \\
\text { Chinese } \\
\text { industry. }\end{array}$ & $\begin{array}{l}\text { Chine } \\
\text { se } \\
\text { ERP } \\
\text { Indust } \\
\text { ry. }\end{array}$ & U.S.A. & $\begin{array}{l}\text { To find the } \\
\text { analysis of } \\
\text { Factors for } \\
\text { ERP } \\
\text { implementati } \\
\text { on. }\end{array}$ & $\begin{array}{l}\text { Chinese } \\
\text { implementat } \\
\text { ions are } \\
\text { presented } \\
\text { and } \\
\text { analyzed. } \\
\text { Eight factors } \\
\text { are } \\
\text { identified. }\end{array}$ \\
\hline
\end{tabular}




\begin{tabular}{|c|c|c|c|c|c|c|c|}
\hline & & & & & & & $\begin{array}{l}\text { Implications } \\
\text { of the } \\
\text { findings for } \\
\text { future ERP } \\
\text { implementat } \\
\text { ions in } \\
\text { China are } \\
\text { discussed. }\end{array}$ \\
\hline 16 & $\begin{array}{l}\text { Vincen } \\
\mathrm{t} \quad \mathrm{A} . \\
\text { Mabert } \\
\text { Ashok } \\
\text { Soni, } \\
\text { M.A. } \\
\text { Venkat } \\
\text { araman } \\
\text { an } \\
2006 .\end{array}$ & $\begin{array}{l}\text { Field study } \\
\text { Case } \\
\text { studies \& } \\
\text { data } \\
\text { collection }\end{array}$ & $\begin{array}{l}\text { DEA \& } \\
\text { ERP } \\
\text { Data } \\
\text { Envelopm } \\
\text { ent } \\
\text { Analysis. }\end{array}$ & $\begin{array}{l}\text { Of the } \\
78 \\
\text { Respo } \\
\text { nses, } \\
77 \text { had } \\
\text { alread } \\
\text { y } \\
\text { imple } \\
\text { mente } \\
\text { d } \\
\text { ERP } \\
\text { Syste } \\
\text { ms. }\end{array}$ & $\begin{array}{l}\text { United } \\
\text { States. }\end{array}$ & $\begin{array}{l}\text { To analyze } \\
\text { empirical } \\
\text { data to verify } \\
\text { hypotheses, } \\
\text { calculate } \\
\text { variances, } \\
\text { and identify } \\
\text { critical } \\
\text { factors } \\
\text { contributing } \\
\text { to outcomes } \\
\text { of interest. }\end{array}$ & $\begin{array}{l}\text { Provide } \\
\text { greater } \\
\text { Insight. } \\
\text { Each } \\
\text { provides } \\
\text { unique } \\
\text { perspectives } \\
\text { into the } \\
\text { process and } \\
\text { helps to } \\
\text { develop a } \\
\text { complete } \\
\text { picture of } \\
\text { the ERP } \\
\text { landscape. }\end{array}$ \\
\hline 17 & $\begin{array}{l}\text { Boo } \\
\text { Young } \\
\text { Chung } \\
\text { Mirosł } \\
\text { aw J. } \\
\text { Skibni } \\
\text { ewski, } \\
\text { Henry } \\
\text { C. } \\
\text { Lucas } \\
\text { Jr.; \& } \\
\text { Young } \\
\text { Hoon } \\
\text { Kwak, } \\
\text { 2008 }\end{array}$ & $\begin{array}{l}\text { DeLone } \\
\text { and } \\
\text { McLean } \\
\text { DM IS } \\
\text { success } \\
\text { model }\end{array}$ & $\begin{array}{l}\text { Success } \\
\text { Factors- } \\
\text { Research } \\
\text { model }\end{array}$ & $\begin{array}{l}\text { Constr } \\
\text { uction } \\
\text { Indust } \\
\text { ry. }\end{array}$ & $\begin{array}{l}\text { Korea } \\
\& \\
\text { U.S.A. }\end{array}$ & $\begin{array}{l}\text { The } \\
\text { objective of } \\
\text { this study } \\
\text { was to } \\
\text { identify and } \\
\text { analyze } \\
\text { critical } \\
\text { factors that } \\
\text { need to be } \\
\text { considered to } \\
\text { ensure } \\
\text { successful } \\
\text { ERP system } \\
\text { implementati } \\
\text { on. }\end{array}$ & $\begin{array}{l}\text { Perceived } \\
\text { usefulness. } \\
\text { 2) } \\
\text { Subjective } \\
\text { norm had a } \\
\text { significant } \\
\text { association } \\
\text { with } \\
\text { perceived } \\
\text { usefulness. }\end{array}$ \\
\hline 18 & $\begin{array}{l}\text { DESH } \\
\text { PAND } \\
\text { E } \\
\text { AMIT } \\
\text { A. , } \\
2008\end{array}$ & $\begin{array}{l}\text { Motivation } \\
- \\
\text { based } \\
\text { multi- } \\
\text { source } \\
\text { active } \\
\text { learning } \\
\text { methodolo } \\
\text { gy }\end{array}$ & $\begin{array}{l}\text { Game } \\
\text { based } \\
\text { Learning } \\
- \\
\text { Simulatio } \\
\text { n } \\
\text { Game. }\end{array}$ & $\begin{array}{l}\text { Learni } \\
\text { ng. }\end{array}$ & U.S.A. & $\begin{array}{l}\text { The } \\
\text { objective is } \\
\text { to led } \\
\text { learning and } \\
\text { collaborative } \\
\text { learning } \\
\text { through peer- } \\
\text { to-peer } \\
\text { interaction. }\end{array}$ & $\begin{array}{l}\text { Constructivi } \\
\text { st learning } \\
\text { by the use of } \\
\text { simulation } \\
\text { game. }\end{array}$ \\
\hline 19 & $\begin{array}{l}\text { Severi } \\
\text { ng V. } \\
\text { Grabsk } \\
\text { i }^{\text {a, }}, \\
\text { Stewar } \\
\text { t A. } \\
\text { Leech, } \\
2007\end{array}$ & $\begin{array}{l}\text { ERP } \\
\text { implementa } \\
\text { tion } \\
\text { projects - } \\
\text { Control } \\
\text { modes }\end{array}$ & $\begin{array}{l}\text { Projects } \\
\& \\
\text { Survey. }\end{array}$ & $\begin{array}{l}\text { ERP } \\
\text { Softw } \\
\text { are } \\
\text { Indust } \\
\text { ry. }\end{array}$ & $\begin{array}{l}\text { Colorad } \\
\text { o } \\
\text { USA. }\end{array}$ & $\begin{array}{l}\text { To analyze } \\
\& \text { Control for } \\
\text { the } \\
\text { Implementati } \\
\text { on } \\
\text { Of ERP. }\end{array}$ & $\begin{array}{l}\text { A portfolio } \\
\text { of control } \\
\text { modes } \\
\text { should be } \\
\text { utilized. } \\
\text { Complement } \\
\text { ary } \\
\text { Controls. }\end{array}$ \\
\hline
\end{tabular}




\begin{tabular}{|c|c|c|c|c|c|c|c|}
\hline 20 & $\begin{array}{l}\text { Craig } \\
\text { Shephe } \\
\text { rd,Chri } \\
\text { s Cleg } \\
\text { g and } \\
\text { Chris } \\
\text { Stride, } \\
2009\end{array}$ & $\begin{array}{l}\text { multi- } \\
\text { method } \\
\text { analysis }\end{array}$ & $\begin{array}{l}\text { Statistical } \\
\text { Analysis }\end{array}$ & $\begin{array}{l}\text { ERP } \\
\text { Softw } \\
\text { are } \\
\text { Indust } \\
\text { ry \& } \\
\text { Consu } \\
\text { lting } \\
\text { Indust } \\
\text { ry. }\end{array}$ & UK & $\begin{array}{l}\text { To provide } \\
\text { useful } \\
\text { recommenda } \\
\text { tion for } \\
\text { Practitioners } \\
\text { in } \\
\text { ERP } \\
\text { industry. }\end{array}$ & $\begin{array}{l}\text { Identified } \\
\text { several } \\
\text { constructs } \\
\text { for inclusion } \\
\text { in future } \\
\text { studies of } \\
\text { users' } \\
\text { reactions to } \\
\text { ERP } \\
\text { systems. }\end{array}$ \\
\hline
\end{tabular}

\section{Research Method :-}

The tool used for this research paper or the research methodology will be analytical hierarchy process (AHP). This methodology will be highly effective in finding out the barriers of ERP and finding their weights and finding out the consistency and determining the C.R. (Consistency Ratio).

Also AHP helps to resolve any ERP issue which may turn out to be a barrier if not attended. Thus AHP addresses this issue further and bring to the notice of ERP implementation team (expert). Basically AHP is a decision making process or one of the multi criteria decision making (MCDM) process which acts as the deterrent factor for this research work.

\section{Research Findings :}

The findings of this literature review paper aims at providing the list of barriers of ERP while implementing it. Rigorous research has been done to do so. In all, total 200 papers have been referred and of the 200 papers, 51 papers were selected to carry out the research. The research shows that the barriers which are commonly observed are lack of many constructs, are mentioned in the given table 4 . Analytic hierarchy process (AHP) has been used to calculate the pair wise combination of the barriers in and consistency ratio (CR) \& consistency index (CI) can be calculated depending upon their constructs.

It is found that sometimes ERP implementation fails and sometimes it does not fail. There can be many more reasons for the failure of ERP implementation. These are the hindrances or barriers of ERP, so is the topic of research.

\section{Results and CONCLUSION :}

The results show that the barriers which are common are internal factors and external factors in an enterprise and cannot be overlooked while implementing ERP. It shows that the barriers of ERP are mostly observed in large and in SMEs . The reasons for occuring the barriers while implementing ERP are because of many things which are cited in the Table 1- Barriers of ERP.

Thus conclusion is drawn that the barriers of ERP while implementing ERP can be avoided if and only if proper attention is taken. Various risk factors are involved in implementing it. These factors can be overcome by applying analytic hierarchical process which acts as the methodology for this literature review paper. Implementation of ERP is rigorous and costly process and it can be done at ease if these barriers are avoided.

\section{Future scope (research) :}

On this note, lot of research can be done as to why there have been barriers of ERP while implementing it.? For the implementation of ERP, all types of industry is applicable-be it a software ,manufacturing or engineering or any other firm can be used.

As on today lot of research is done on implementing the ERP (or ERP implementation) but the research on the barriers of ERP is totally new and not much aware of. Hence there is a great scope for refining the research on this topic in future.

\section{Acknowledgements:}

I am always indebted to my research guide Dr.Santosh B. Rane who is a Professor in Sardar Patel College of Engineering (SPCE), Mechanical Engg.Dept. at Andheri (w), Mumbai. He has really guided throughout my research work and helped me frequently. I am always grateful to him. Secondly I am also thankful to my family since I was not sparing time for them. Also, I am very much thankful to referees for the favorable remarks given for this literature review paper. I thank all of them. 


\section{References}

[1] S. Shankarnarayanan, ERP systems - using IT to gain a competitive advantage, March 23, 2000

[2] C. Loizos, ERP: Is it the ultimate software solution, Industry Week 7 (1998)33.

[3] C. Dillon, Stretching toward enterprise flexibility with ERP, APICS - The Performance Advantage (October)(1999)38-43.

[4] S. Cliffe, ERP implementation, Harvard Business Review 77 (1) (1999)16-17.

[5] T. Davenport, Putting the enterprise into the enterprise system, Harvard Business Review 76 (4)(1998)121-132 .

[6] S. Langdoc, ERP reality check for scared CIOs, PC Week 15 (38)(1998)88.

[7] G. Langenwalter, Enterprise Resources Planning and Beyond Integrating Your Entire Organization, St. Lucie Press, Boca Raton, FL, 2000.

[8] C. Ptak, E. Schragenheim, ERP: Tools, Techniques, and Applications for Integrating the Supply Chain, St. Lucie Press, Boca Raton, FL, 2000.

[9] C. Ptak, ERP implementation—surefire steps to success, ERP World Proceedings, August 1999

[10] J. Krupp, Transition to ERP implementation, APICS - The Performance Advantage (October)(1998) 4-7.

[11] G. Langenwalter, Enterprise Resources Planning and Beyond: Integrating Your Entire Organization, St. Lucie Press, Boca Raton, FL, 2000.

[12] D. McCaskey, M. Okrent, Catching the ERP second wave, APICS - The Performance Advantage (December)(1999) 34-38

[13] T. Minahan, Enterprise resource planning, Purchasing 16 (1998)112-117.

[14] H. Oden, G. Langenwalter, R. Lucier, Handbook of Material and Capacity Requirements Planning, McGraw-ill, New York, 1993

[15] O. Volkoff, B. Sterling, P. Nelson, Getting your money_s worth from an enterprise system, Ivey Business Journal (1)(1999)54-57.

[16] Ike C.Ehie, Mogens Madsen; Identifying critical issues in enterprise resource planning (ERP) implementation, Computers in Industry(2005)

[17] Chun-Chin Wei et al. ; An AHP based approach to ERP system selection , Int. J. of Prod.Economics 96 (2005) 47-62

[18] Elisabeth J.Umble, Ronald R.Haft, M. Michael Umble ; Enterprise resource planning :Implementation procedures and critical success factors, European Journal of Operations Research 146 (2003) 241-247.

[19] Zhe Zhang, Matthew K.O.Lee, Pei Huang, Liang Zhang, X. Zhang; A framework of ERP systems implementation success in China : An empirical study, Int. J. of Production Economics, (2005).

[20] O.S. Vaidya, S.Kumar ; Analytic Hierarchy Process : An Overview of Applications, European J. of OR 169 (2006) 1-29.

[21] Y. Xue, H. Liang, W.R.Boulton, Charles A.Snyder ; ERP implementation failures in China : Case studies with implications for ERP vendors, Int. J. of Production Economics 97 (2005) 279-295.

[22] T.-H. Chang et al. ; Measuring the success possibility of implementing ERP by utilizing the Incomplete Linguistic Preference Relations , Applied Soft Computing 12 (2012).

[23] C. Macharis et al.; PROMETHEE and AHP: The design of operational synergies in multi criteria analysis, European J.of O.R.(2004).

[24] G. Noci, G. Toletti; Selecting quality- based programmes in small firms :A comparison between the fuzzy linguistic approach and the analytic hierarchy process, Int. .J. of Production Economics 67 (2000) 113-133.

[25] M. Bevilacqua, M. Braglio ; The analytic hierarchy process applied to maintenance strategy selection, Reliability Engineering and System Safety 70 (2000) 71-83.

[26] M. J. Liberatore et al. ; The analytic hierarchy process in medical and health care decision making - A literature review, European J. of OR (2008) 194-207.

[27] M.K.Chen, S.C.Wang; The critical factors of success for information service industry in developing international market - Using AHP approach., Expert Systems with Applications 37 (2010) 694-704.

[28] E.K.Delice, Z.G.; The usability analysis with heuristic evaluation and analytic hierarchy process. , International J. of Industrial Ergonomics 39 (2009) 934-939.

[29] Wen - Hsien Tsai et al. ; An empirical investigation of the impacts of internal/external facilitators on the project success of ERP : A structural equation model, Decision Support Systems 50 (2011) 480-490.

[30] H.R.Yen, C.Sheu ; Aligning ERP implementation with competitive priorities of manufacturing firms : An exploratory study, Int. J. of Prod. Economics 92 (2004) 207-220.

[31] S. Lee et al. ; Using AHP to determine intangible priority factors for technology transfer adoption , Expert Systems with Applications 39 (2012).

[32] Amin Amid et al. ; Identification and classification of ERP critical failure factors in Iranian industries , Information Systems 37(2012).

[33] D. O’Leary, Enterprise Resource Planning Systems: Systems, Life Cycle, Electronic Commerce, and Risk, Cambridge University Press, 2000.

[34] A. Hawari, R. Heeks, Explaining ERP failure in a developing country: a Jordanian case study, Journal of Enterprise Information Manage- ment 23 (2) (2010) 135-160.

[35] O.G. Kayas, et al., The panoptic gaze: analyzing the interaction between enterprise resource planning technology and organizational culture, International Journal of Information Management 28 (6) (2008) 446-452.

[36] J. Lattin, J.D. Carroll, P.E. Green, Analyzing Multivariate Data, Thomson Learning, Inc., Publishing, California, 2003.

[37] C. Holland, B. Light, A stage maturity model for enterprise resource planning systems use, The DATA BASE for Advances Information Systems 32 (2) (2001). 